\title{
الآثار المترتبة على العقد الموقوف
}

كيمِ إعداد الأستاذ

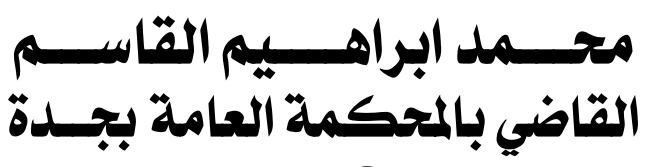

mohqasem11@gmail.com 


\section{الآثار المترتبة على العقد الموقوف}

$$
\begin{aligned}
& \text { محمد ابراهيم القاسم } \\
& \text { قسم الفقه المقارن - المحكمة العامة - جدة - السعودية. }
\end{aligned}
$$

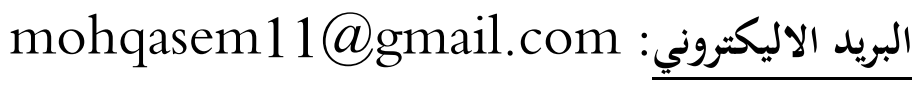

الملخص : المكول

يمكن القول أن العقد الموقوف هو العقد الذي يرتب أثنره في الحال وتكون صحته

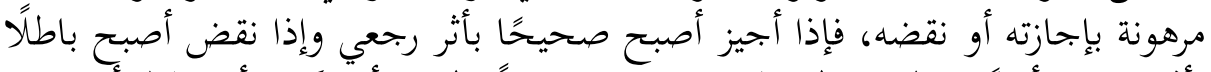

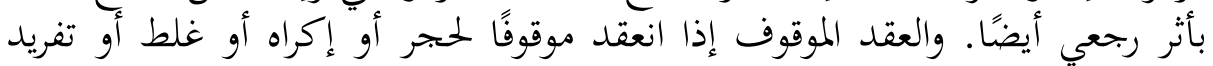

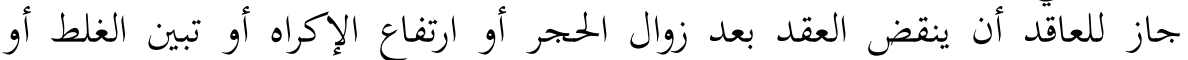

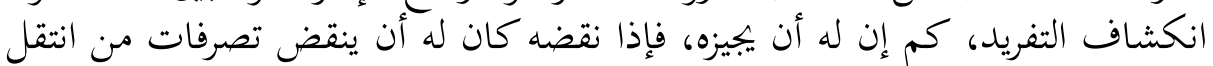

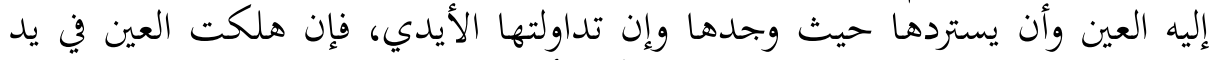

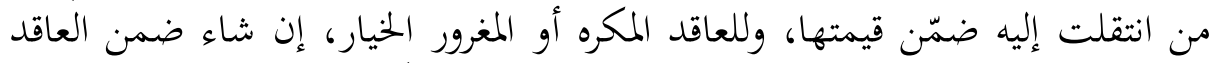

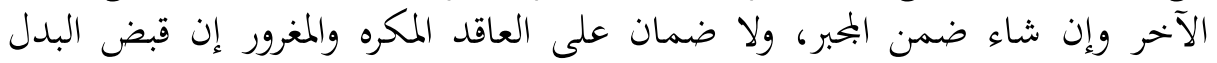

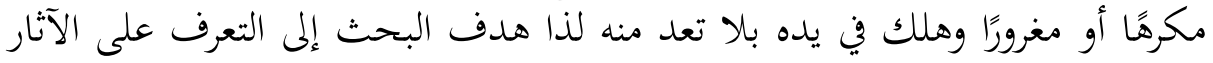

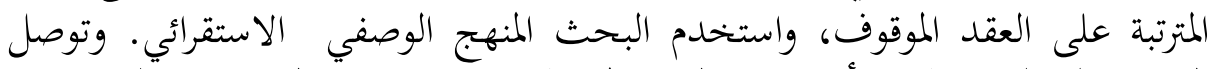

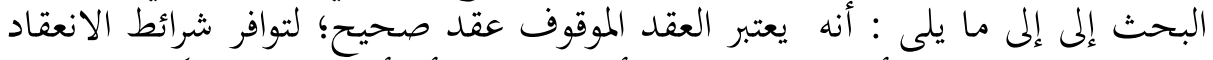

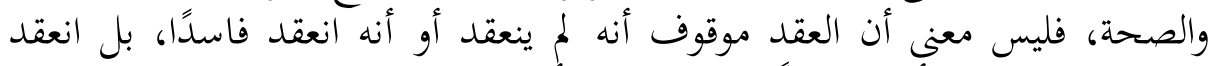

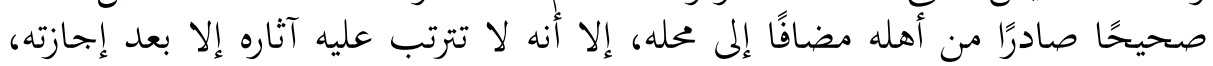

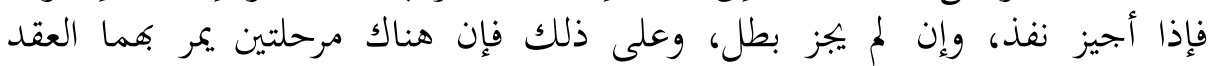

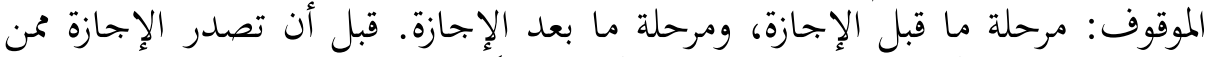

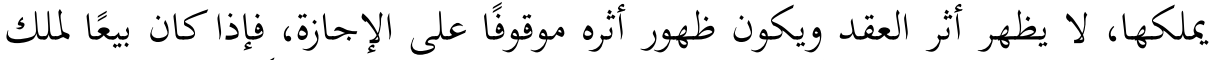

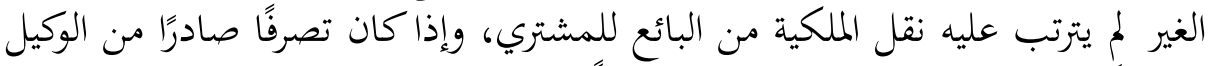

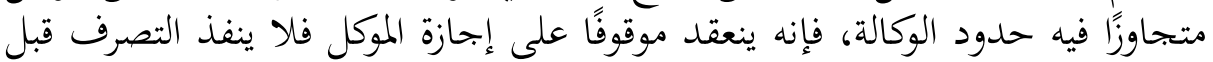

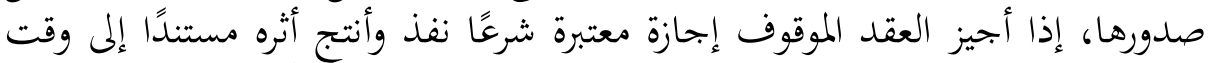

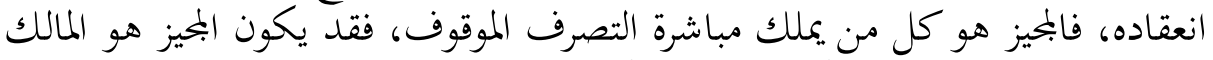

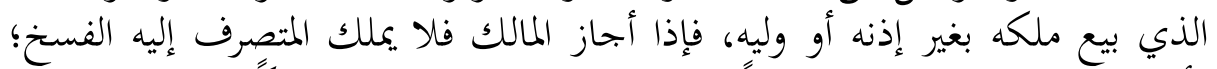

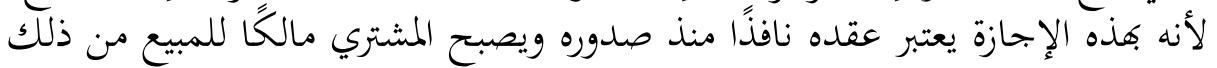

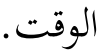
الكلمـات المفتاحيـة : العقــ الموقوف - الحجـر - ارتفـاع الإكراه - التفريد - عقـد 


\section{Implications for the suspended contract}

Muhammad Ibrahim al-Qasim

Comparative Jurisprudence Department - General Court Jeddah - Saudi Arabia.

e-mail: mohqasem11@gmail.com

\section{Abstract:}

It can be said that the suspended contract is the contract whose effect is arranged immediately and its validity depends on its approval or veto, and if it is passed it becomes valid retroactively and if it void it becomes void with retroactive effect as well. And the suspended contract, if it was held suspended for a stone, coercion or mistake, is a discretion permissible. The contract may revoke the contract after the demise of the stone or the height of coercion, or it turns out the mistake or exposure of discretization, how much he has to authorize. He found it, and if hands passed it, if the eye perished in the hand of the one to whom it was transferred, guarantee its value, and the forced or arrogant contractor had the option. If he wanted within the other contract and if he wanted within the compulsory, there is no guarantee on the forced and arrogant contractor if the allowance is taken forcibly or arrogant and perished in his hand without counting from it Therefore, the research aimed to identify the effects of the suspended contract, and the research used the descriptive inductive method. The research reached the following: - He considers the suspended contract to be a valid contract; For the presence of the tapes of validity and validity, it does not mean that the contract is suspended because it was not concluded or that it was corrupted, but rather a valid contract issued by his family in addition to his place, except that it does not result in 
his effects until after his approval, so if it is permitted, it is executed, and if he has not sanctioned a hero, accordingly, then the There are two phases through which the suspended contract passes: pre-leave and post-leave.- Before the license is issued to the one who owns it, the effect of the contract does not appear and the effect of the contract is visible on the leave, so if it is a sale to the property of others, it does not result in the transfer of ownership from the seller to the buyer, and if the behavior issued by the agent exceeds the limits of the agency, then it is held on the authorization of the client The action is not carried out before it is issued - If the suspended contract has authorized a legitimate leave that has been implemented and produced its effect based on the time of its conclusion, the reward is whoever directly possesses the suspended action, then the permissible may be the owner who sold his property without his permission or his guardian, and if the owner permits, the disposer does not have the annulment; Because on this leave his contract is effective from its issuance and the buyer becomes the owner of the sale from that time.

Keywords: suspended contract - stone - high coercion singularity - valid contract. 


\section{年}

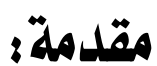

إن فقهاء الشريعة الإسلامية أفاضوا في دراسة العقود وتبسيط مسائلها، كما أولوا

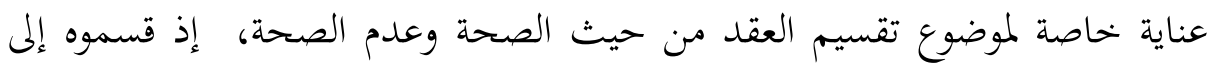

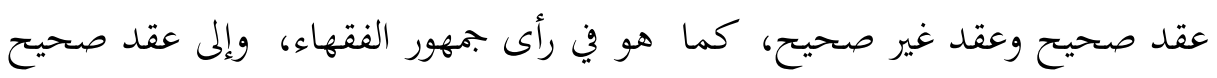

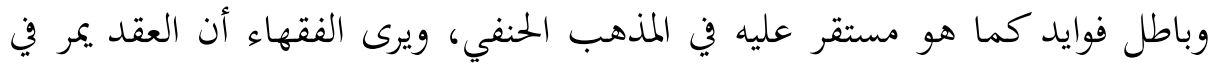

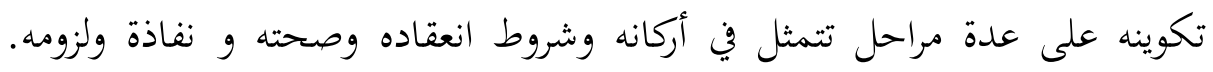

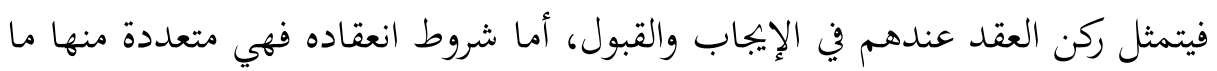

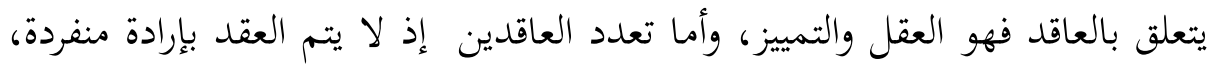

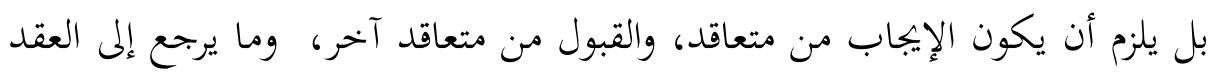

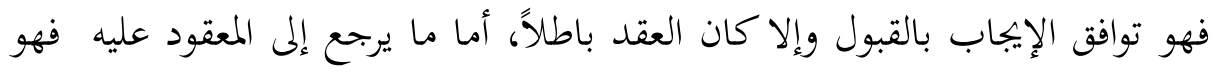

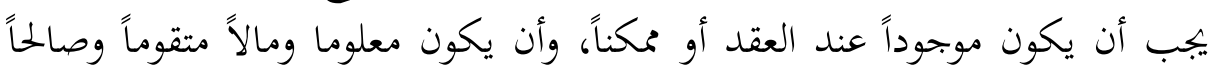
للتعامل فيه.

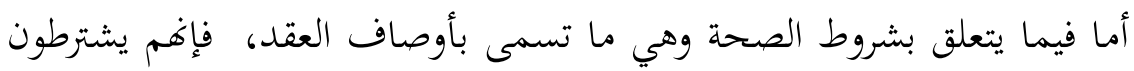

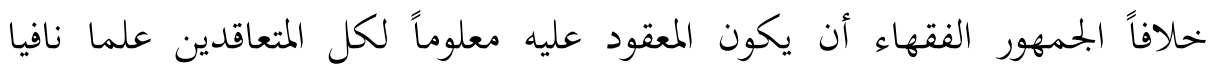

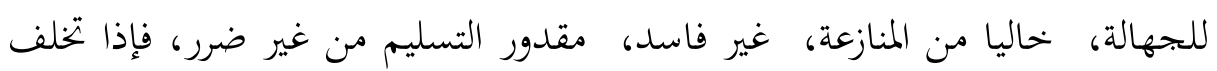

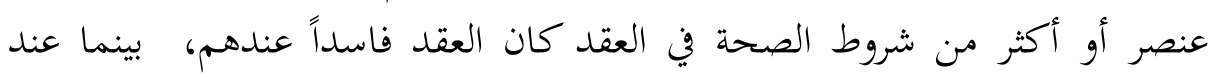

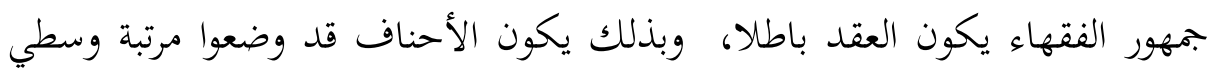

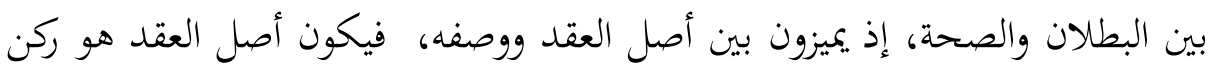

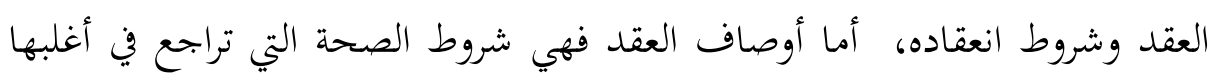

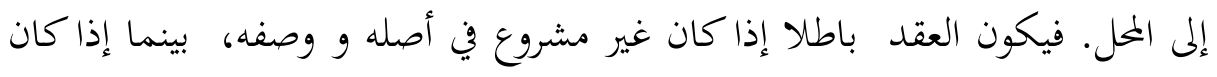

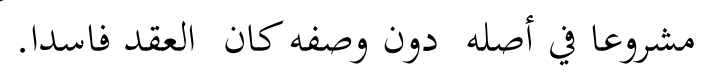

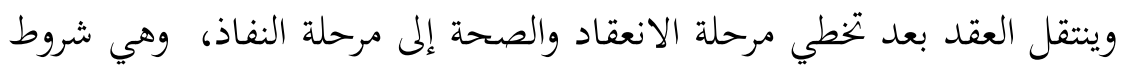

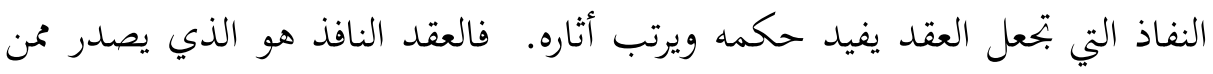

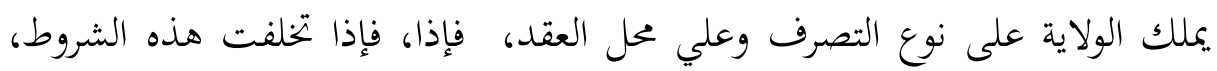

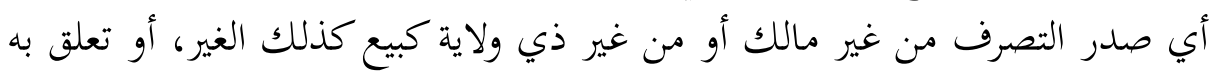


حب الغير، كأن يبيع شيئا مرهونة، كأن العقد موقوف النفاذ على إجازة الحق في

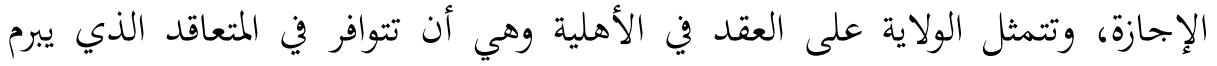

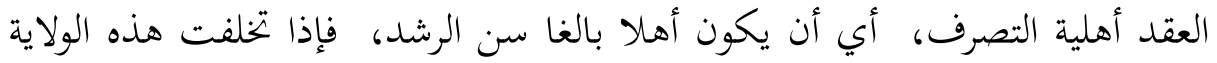

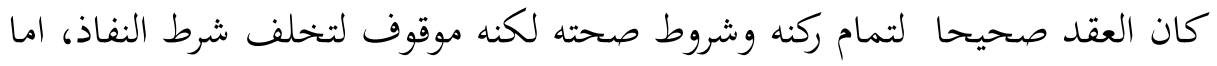

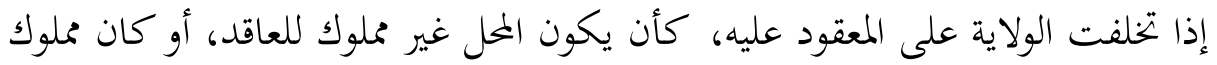

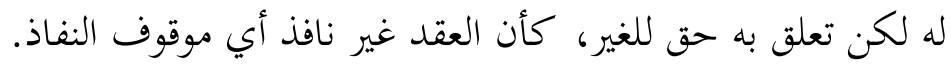

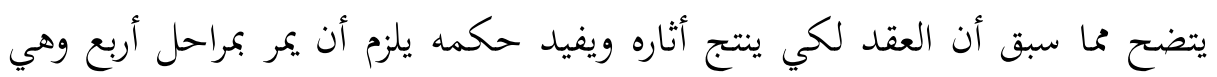

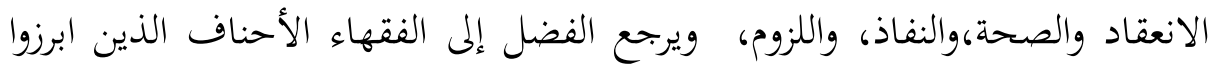

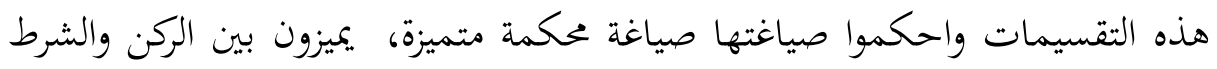

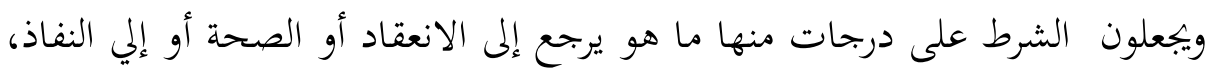

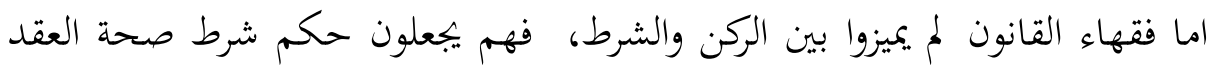

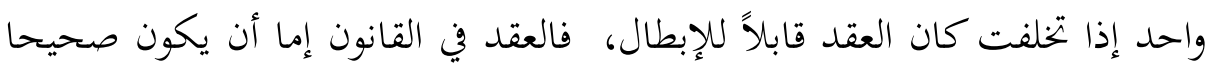
وإما باطلا أو قابلا للإبطال.

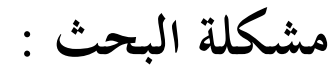

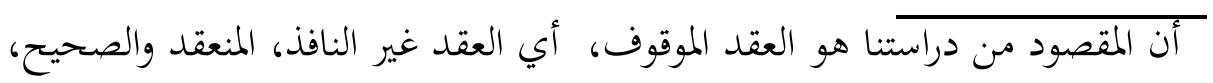

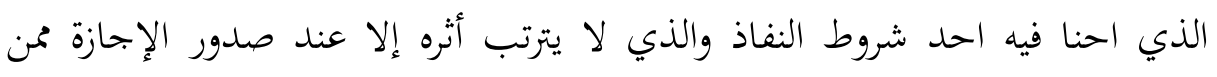

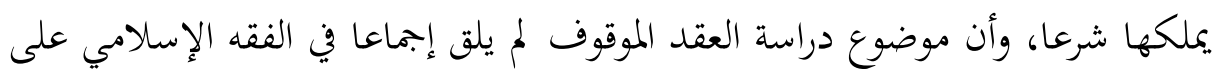

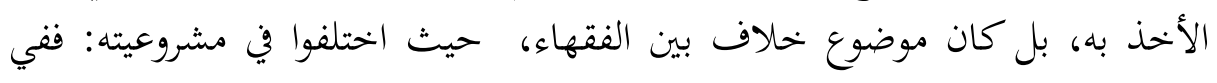

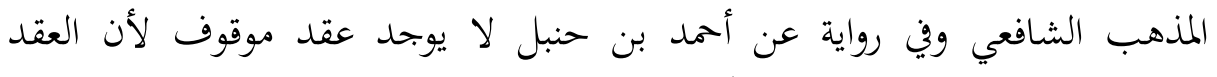

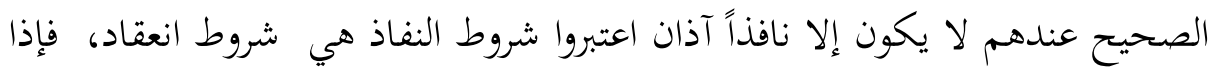

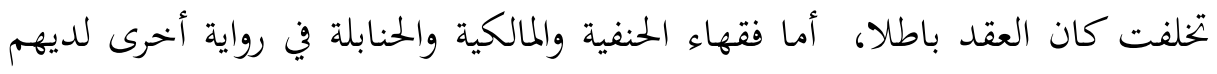
فإن العقد يكون موقوفا إذا تخلفت شروط أماء نفاء الحفاذه التي هي ولاية العاقد أو ولاية المعقود عليه.

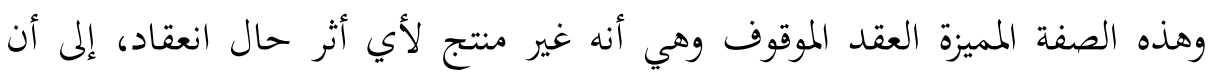

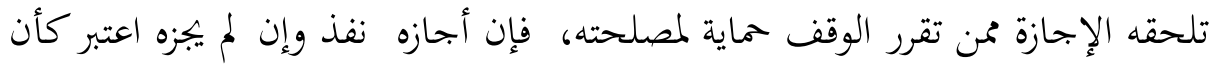

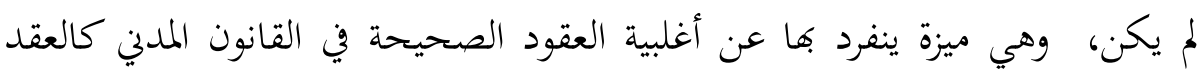

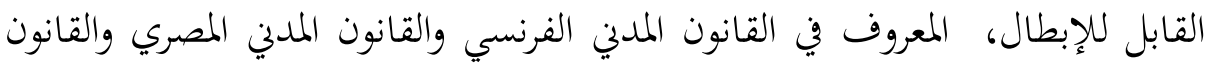




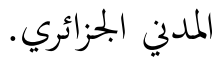

والأصل العام في العقد أن يكون منتجا لآثاره حال انعقاده أما عدم النفاذ فيعتبر

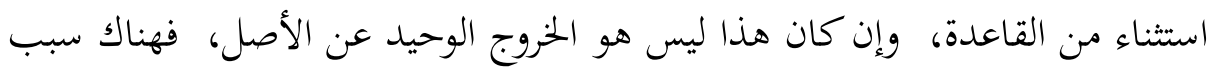

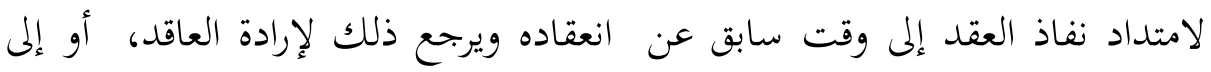

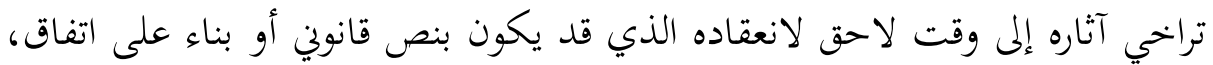

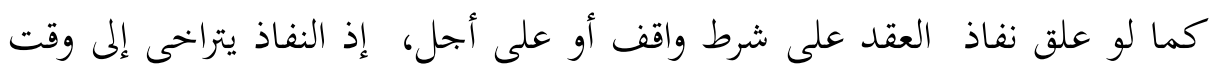
تحقق الشرط أو حلول الأجل.

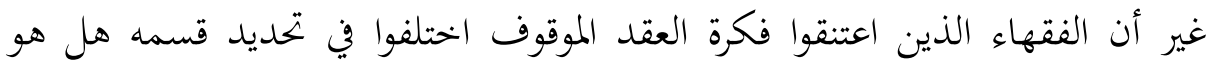

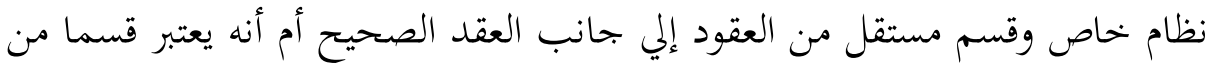

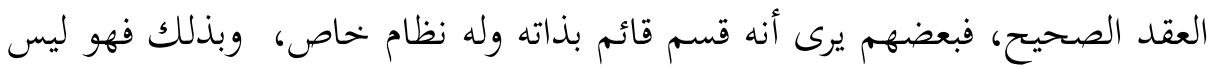

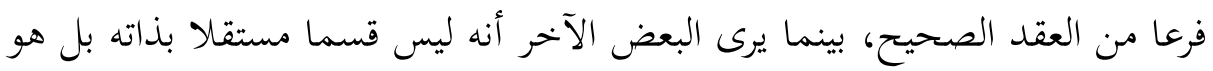

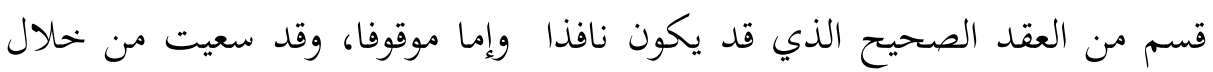

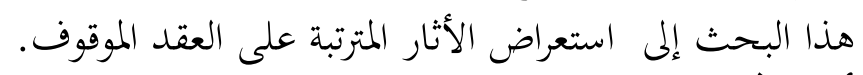
أهداف البحث : البحثن

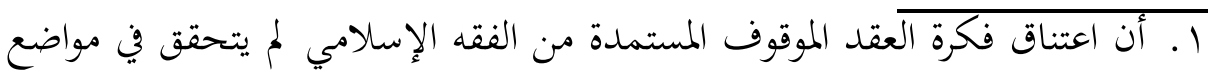

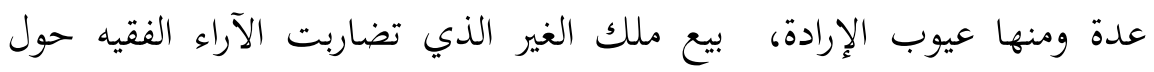
حكمه، حكم بتحاوز الوكيل حدود وكالته في غير الحالات الات المستثناة.

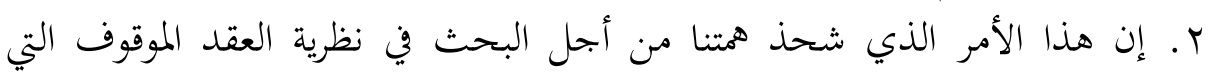

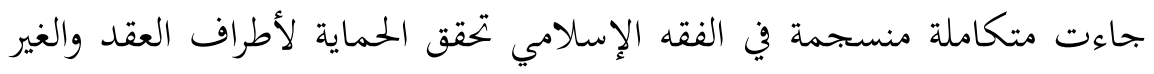

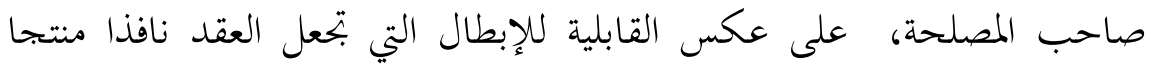

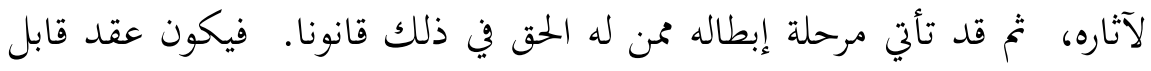

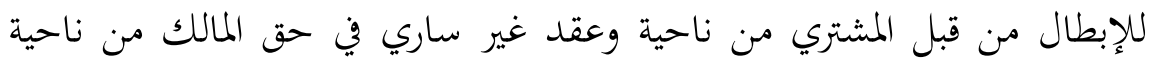

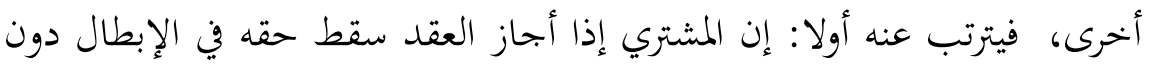

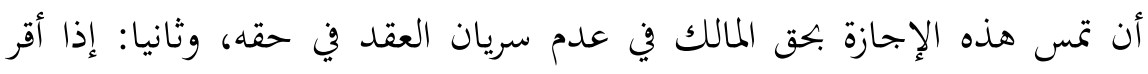

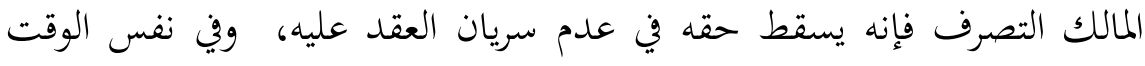

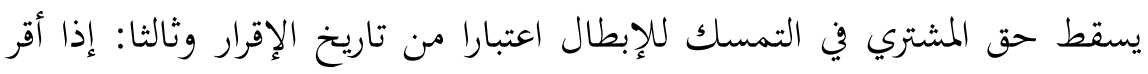

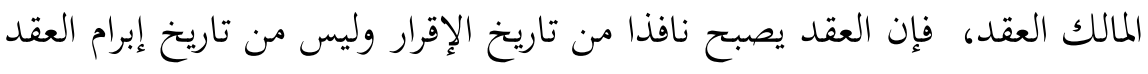


ويترتب عليه أن الإقرار لا يضر بالحقوق التي كسبها الغير من المالك قبل صدور الإقرار.

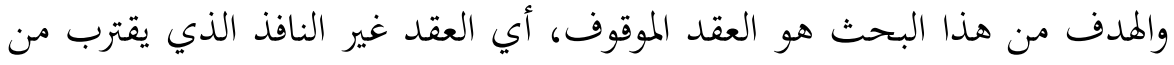

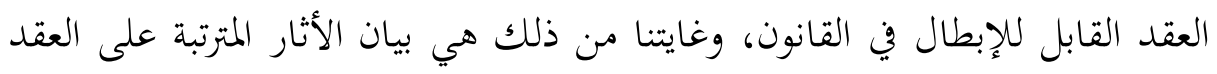

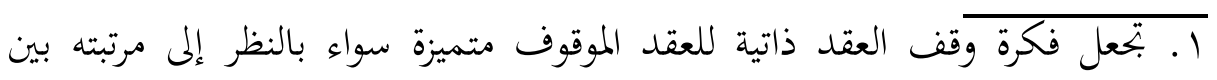

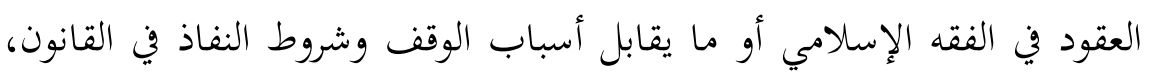

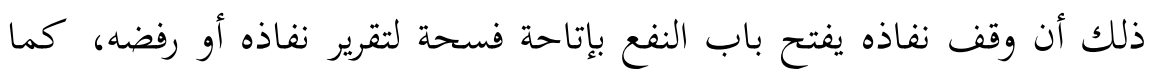

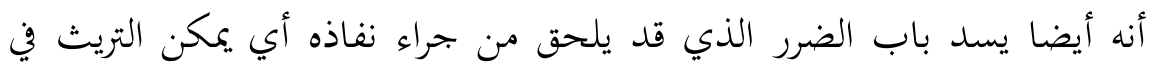

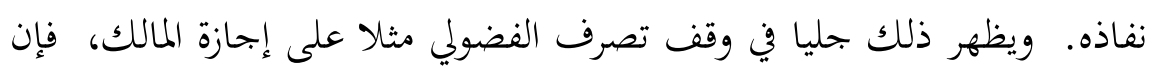

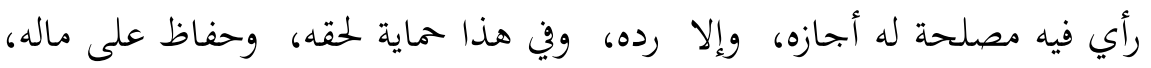

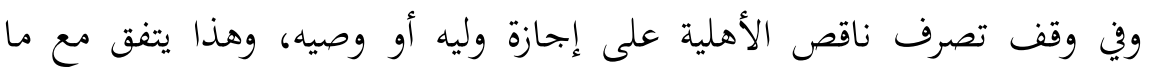

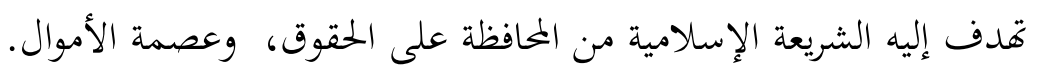

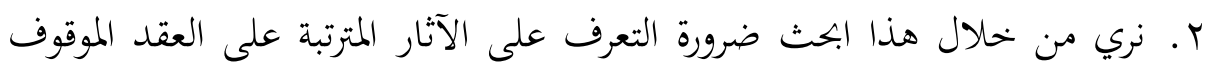

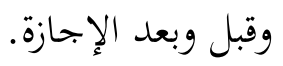

\section{الدراسات السابقة : المئب}

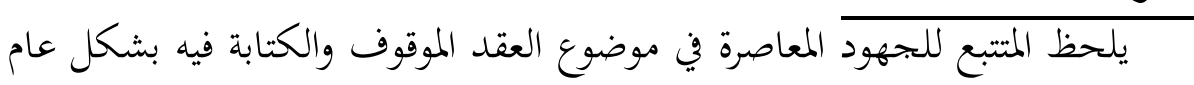

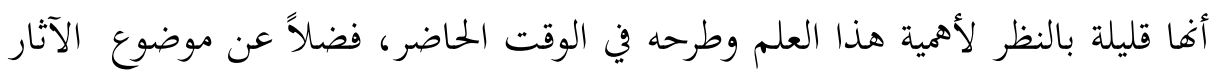

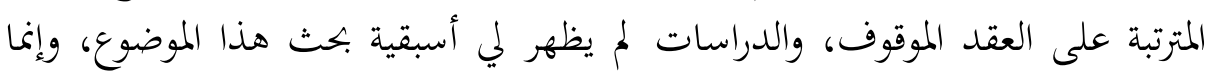

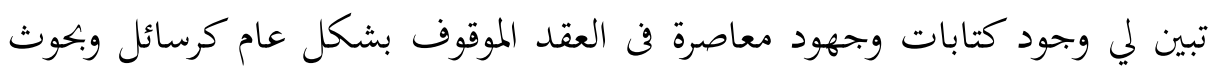

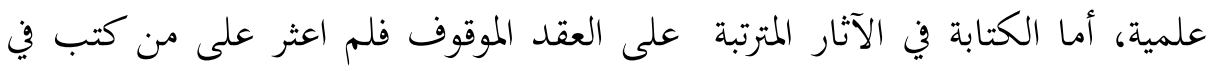

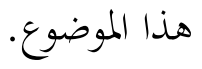

منهج البحث : البحث على المنهج التحليلي بمعالجة كل ما تم الوقوف عليه وجمعه من تعاريف 
لغوية واصطلاحية وأراء فقهية ونصوص قانونية وأحكام واجتهادات قضائية في نسق

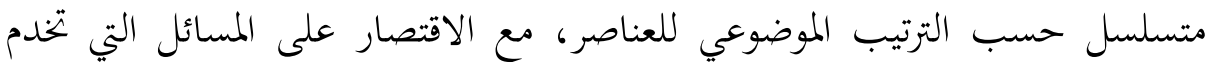
البحث بصورة مباشرة. حدود البحث : اقتصر البحث على دراسة الآثار المترتبة على العقد الموقوف.

$$
\begin{aligned}
& \text { خطة البحث : (1) - (1) } \\
& \text { المطلب الأول: تعريف العقد الموقوف. } \\
& \text { المطلب الثاني: الخلاف الفقهي في العقد الموقوف. } \\
& \text { المطلب الثالث: أنواع العقد الموقوف، وفيه فرعان: } \\
& \text { الفرع الأول: وقف العقد لانعدام الولاية على محل العقد. }
\end{aligned}
$$

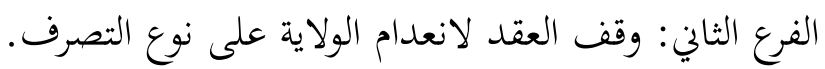

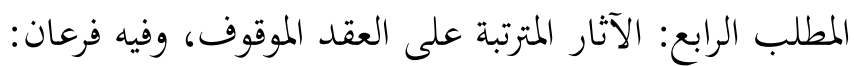

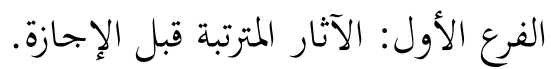

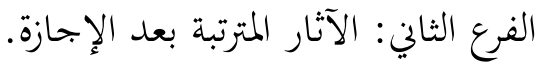




\section{المطلب الأول :تعريف العقد الموقوف}

الموقوف: اسم مفعول من الوقف، وهو لغة: الحبس، وقيل للموقوف: (وقف) من

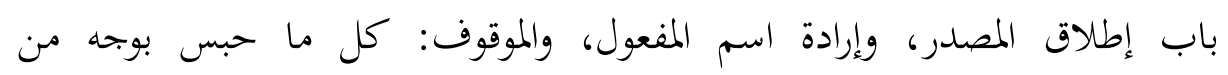

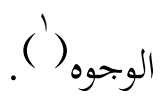

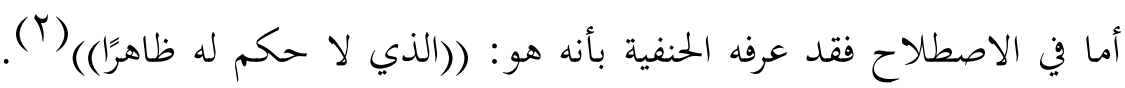

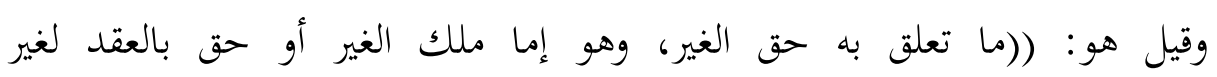
المالك)(") (ك). وقيل هو: (المشروع بأصله ووصفه ويفيد الملك على سبيل

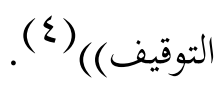
وبتأمل التعريفات السابقة يمكن الوقوف على الملاحظات التالية:

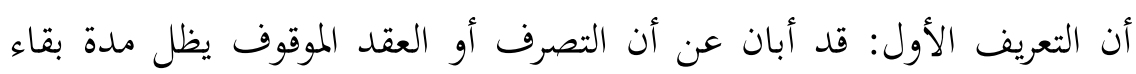

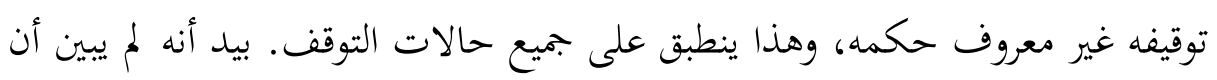
الإجازة أو الرد يؤديان إلى ظهور حكمه (0).

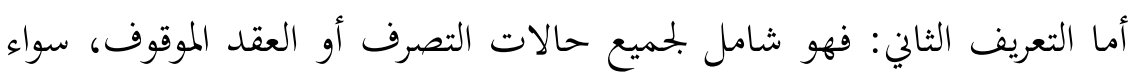

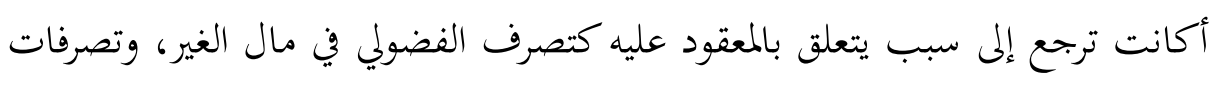

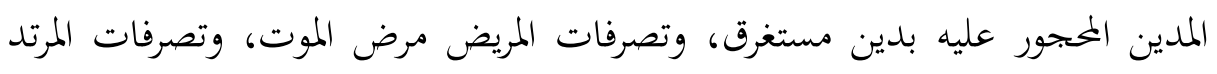

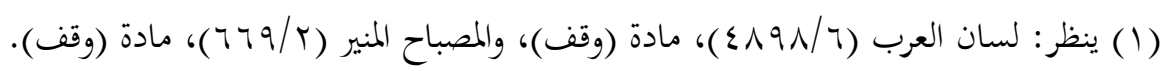

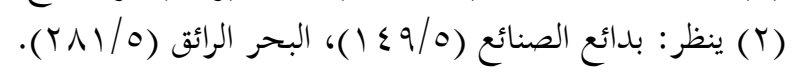

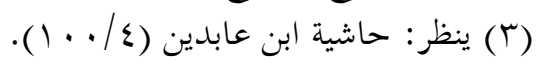

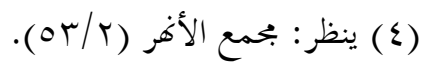

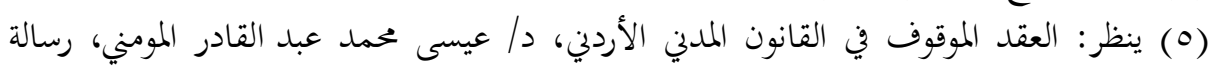
دكتوراه، جامعة عين شمس، ص (· (1). 
عن الإسلام عند أبي حنيفة وبيع المرهون، أم كانت ترجع إلى سبب يتعلق بصلاحية العاقد للتصرف، كالتصرفات الدائرة بين النفع والضرر للصغير المميز، والمحجور عليهما لسفه أو غفلة، باستثناء تصرفات المكره طبقًا لرأي زفر في اعتبارها موقوفة( (1).

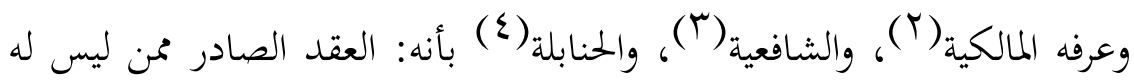

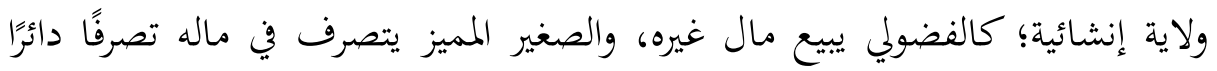

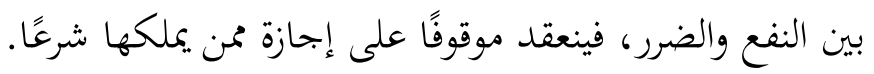
وبالنظر في تعريفات الفقهاء المحدثين للعقد الموقوف يلاحظ اختلاف تعبيراتم فيها،

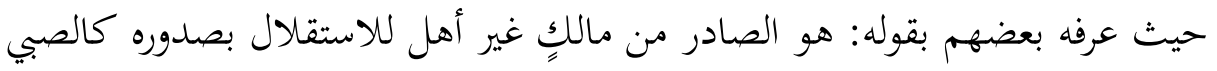

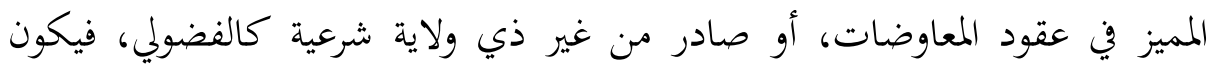

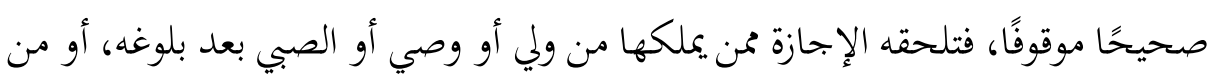
مالك هو أهل للاستقلال بصدوره(0)

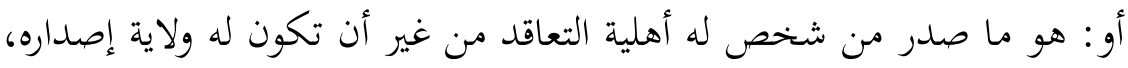

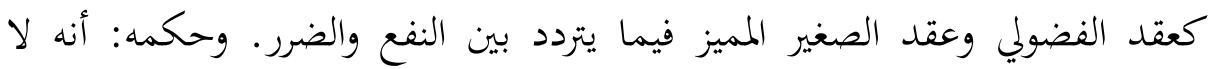
يترتب عليه آثاره إلا إذا أجازه صاحب الشأن الذي يملك إصداره، فإن لم يجيزه

(1) إجازة التصرفات، دراسة مقارنة، د/ محمد بن محمد بن محمد الغشم، رسالة دكتوراه، كلية

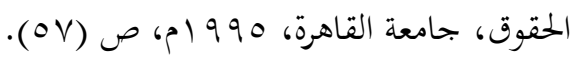

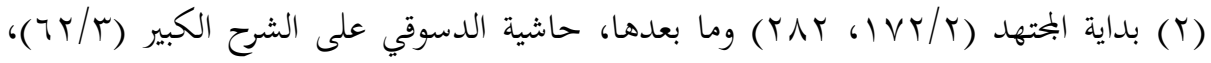

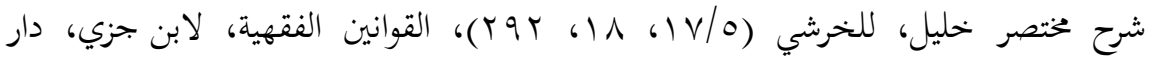

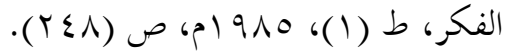

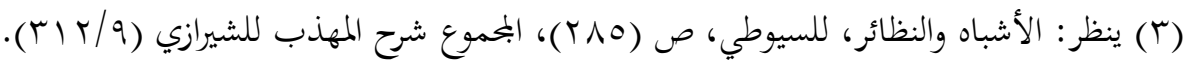

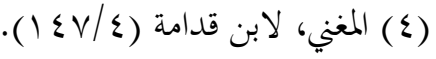
(0) مقالة في العقود والشروط، الشيخ/ أمثل إبراهيم، بحلة القانون والاقتصاد، السنة الرابعة، العدد

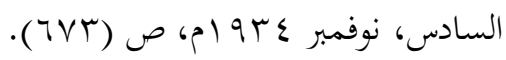


أو: هو قسم من أقسام العقد الصحيح ولكنه غير نافذ إلا بموافقة شخص معين،

فإن أجازه نفذ وإن لم يجزه بطل، ويكون التصرف موقوفًا إذا كان من يباشره ليس له

ولاية مباشرته، ولكنه أهل في ذاته لمذه المباشرة(T).

أو: هو العقد الذي لا يترتب على إنشائه أي أثر من آثاره على الرغم من أنه

عقد صحيح يعترف الشارع بوجوده، بل تتوقف آثاره على إجازته ممن له حق الإجازة

$$
\text { أو ممن له حق مباشرته(r). }
$$

ومن بحمل هذه التعريفات يتبين أن العقد أو التصرف الموقوف هو صحيح في

إنشائه، غير أن نفاذه وترتيب آثاره عليه متوقف على الإجازة ممن يملكها، ولو لم يكن

صحيح الإنشاء أو لم تحصل الإجازة، انعدم التصرف ولم يترتب عليه شيء من آثاره.

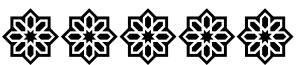

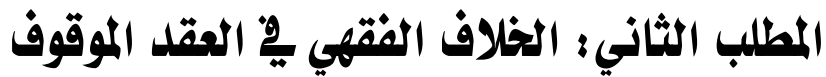

اختلف الفقهاء في حكم العقد الموقوف على قولين:

القول الأول: يرى الحنفية(§)، والمالكية(0)، وأحمد في رواية(†)، والشافعية في

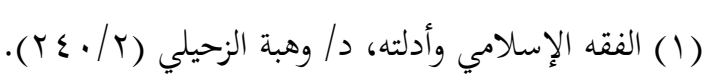

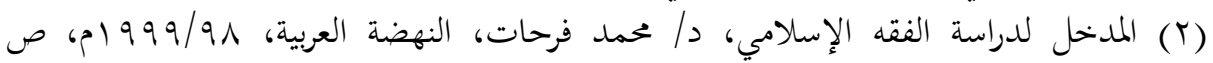

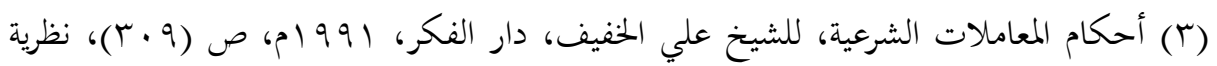

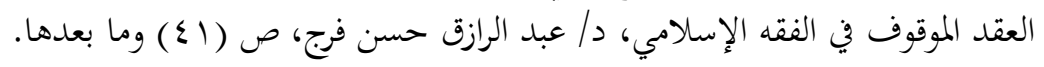

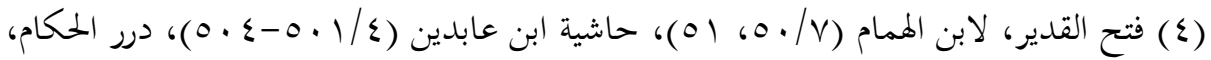

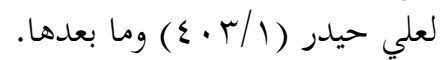

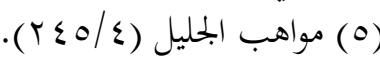

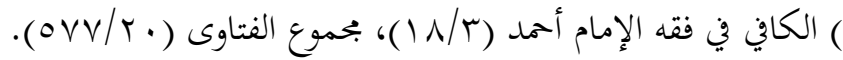


قول (1): أن العقد الموقوف صحيح؛ ذلك أن العقد الموقوف عقد صحيح لتوافر أركانه

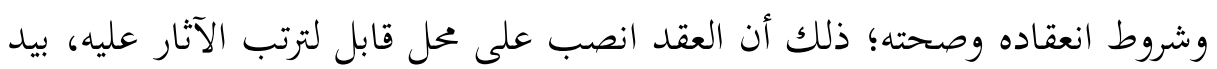

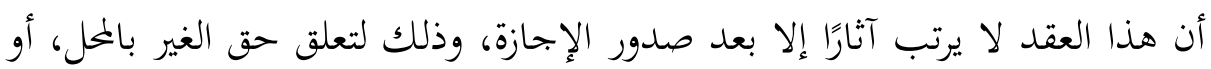
لأن أحد المتعاقدين لا يتمتع بولاية على إنشاء العقد.

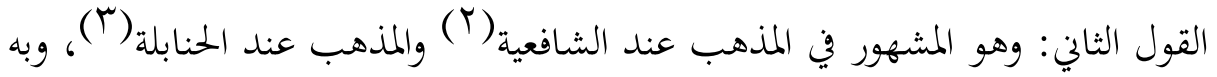
قال أبو ثور وابن المنذر: أن العقد الموقوف باطل ولا يصح بالإجازة(ع). فالقائلون ببطلان العقد الموقوف جعلوا شرطا اكتمال الأهلية والولاية على المحل

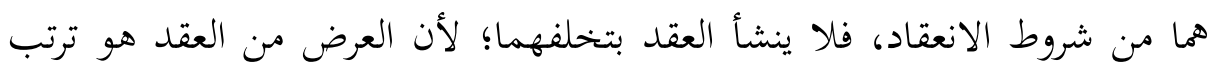

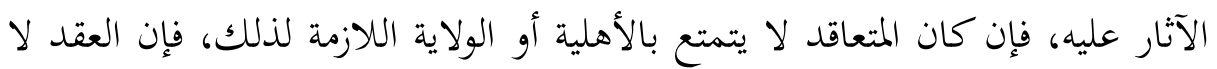

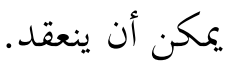

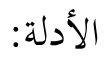
أدلة القول الأول: احتج أصحاب القول الأول القائلون بصحة العقد الموقوف بالكتاب

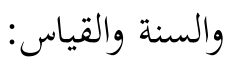
أولاً: الكتاب: احتجوا من الكتاب بما يلي:

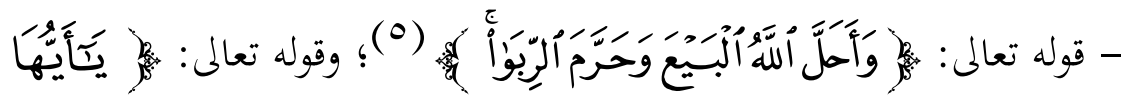

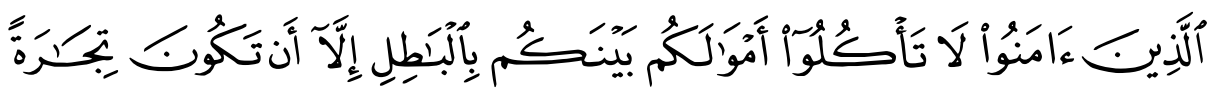
(1) المثثور، الزركشي (r/r/r)، وروضة الطالبين (r/r/r)، الأشباه والنظائر، للسيوطي، ص

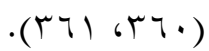

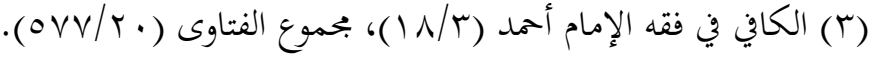

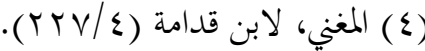

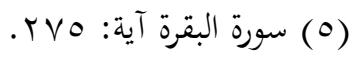




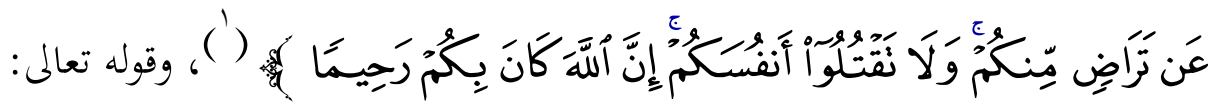

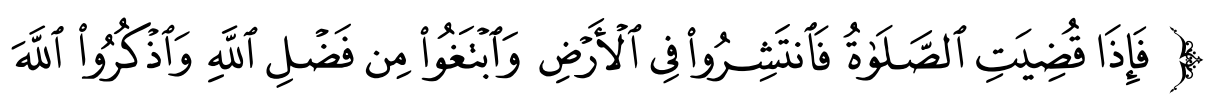

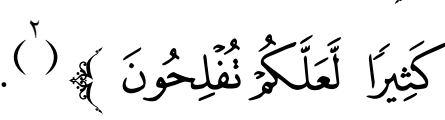

وجه الدلالة من هذه الآيات: أن الله ثَ شرن البيع والشراء والتجارة ابتغاء

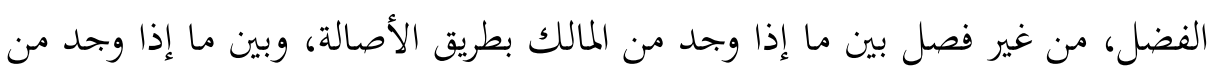

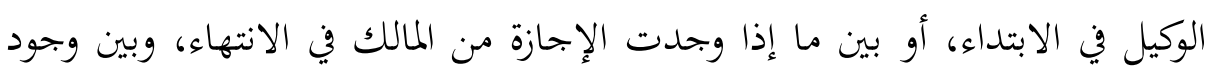
الرضا في التجارة عند العقد أو بعده، فيجب العمل بإطلاقها إلا ما خص بدليل ("). ثانيًا: السنة:

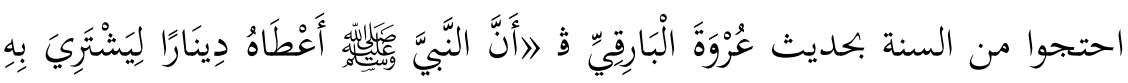

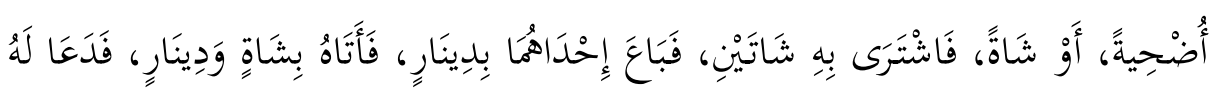

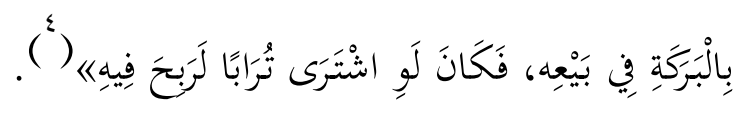

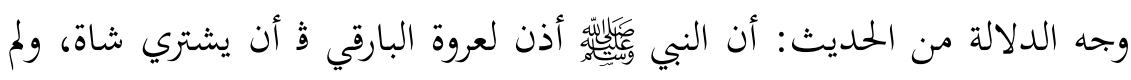

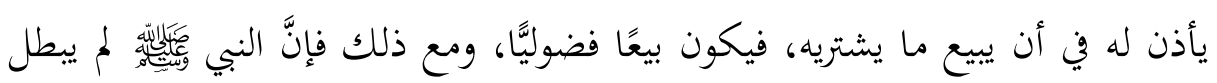

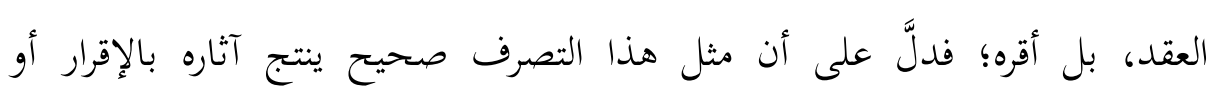
(الإجازة)

ثالثًا: القياس:

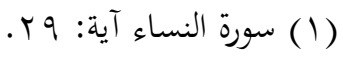

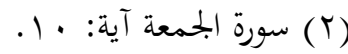

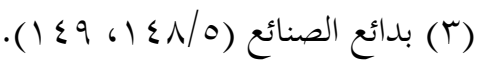

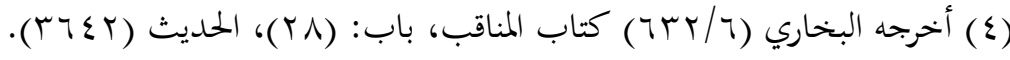

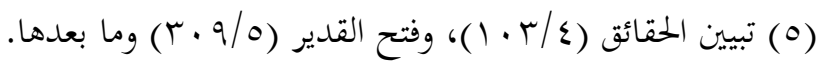


احتجوا من القياس بأن قاسوا التصرف الموقوف على وصية المدين بدين مستغرق، كبيع المرهون، فإنه ينعقد موقوفًا على إجازة المرتن، وعلى العقد المشروط الذي فيه الخيار؛ لأن الوصية من المدين بدين مستغرق لماله تتوقف على إجازة المستحق، فالوصية تصرف صحيح، ولا حكم له في الحال، وكذلك البيع المشروط فيه الخيار تصرف صحيح ولا حكم له في الحال حتى يتحقق كمال الرضا بين

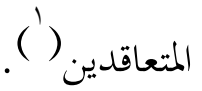
أدلة القول الثاني: احتج أصحاب القول الثاني على بطلان العقد الموقوف بالسنة

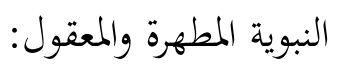
أولاً: السنة:

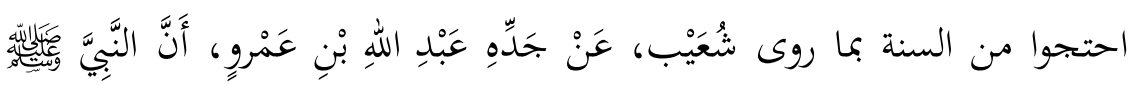

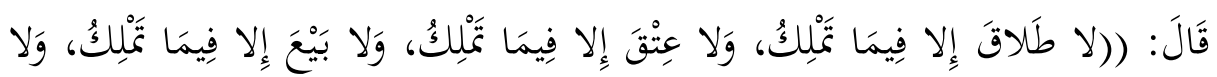

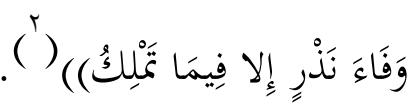

$$
\begin{aligned}
& \text { ثنانيًا: المعقول: }
\end{aligned}
$$

احتجوا من المعقول على البطلان بأن الفضولي أحد طرفي البيع، فلم يقف البيع على الإجازة كالقبول؛ ولأنه باع ما لا يقدر على تسليمه كالسمك في الماء والطير في

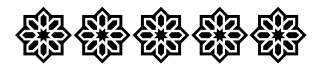

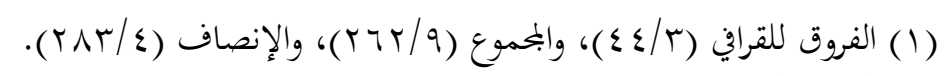

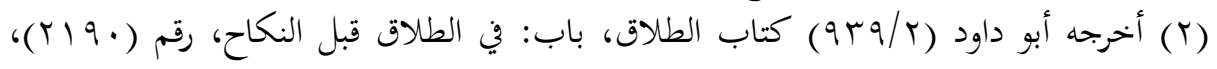

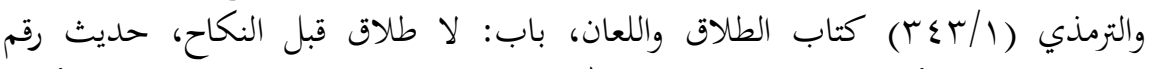

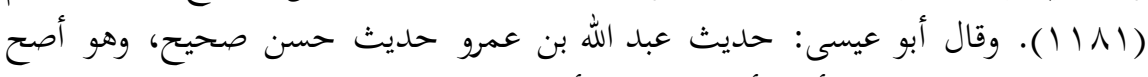

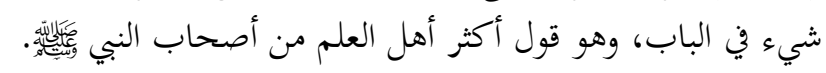

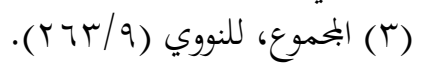




\section{المطلب الثالث: أنواع المقلد الموقوف}

سبق في تعريف العقد الموقوف، أنه العقد الذي تخلفت فيه شروط النفاذ، وهما

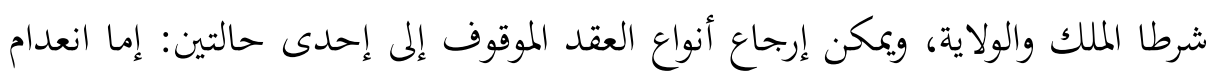

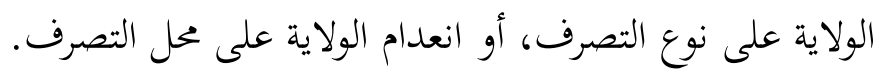

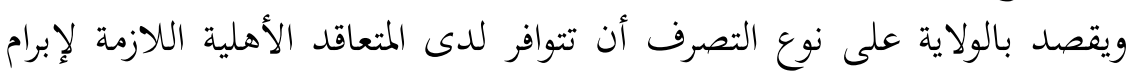

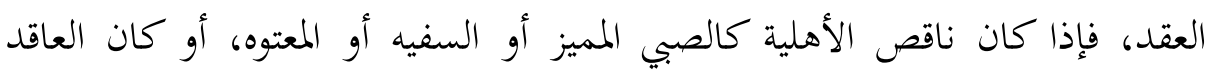

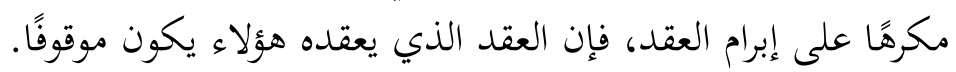

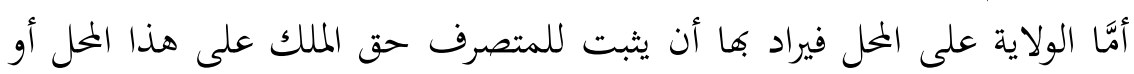
النيابة عن المالك، وألا يتعلق بالمحل حق الغير.

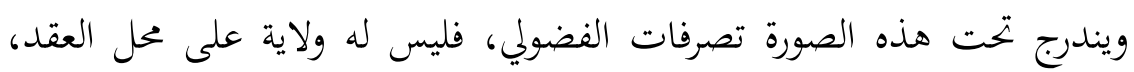

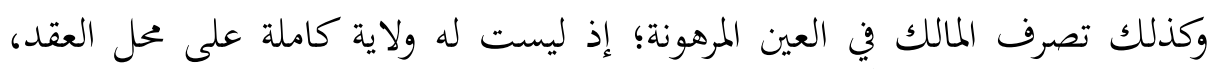

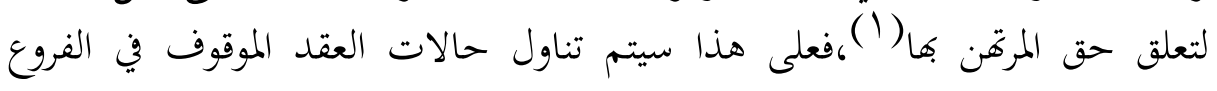
التالية:

الفرع الأول: وقف العقد لانعدام الولاية على محل العقد:

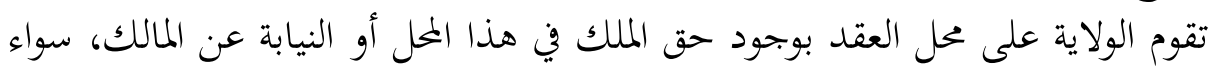

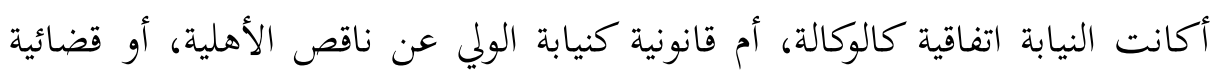
كنيابة الوصي عن السفيه أو ذي الغفلة، أو من يعينه القاضي للنيابة عنه.

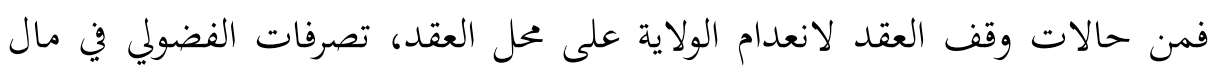

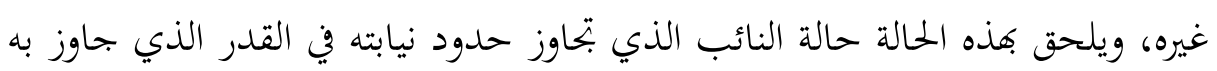

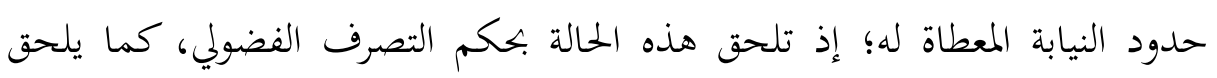

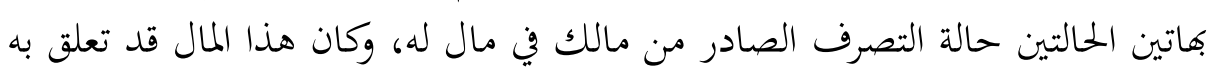
حق للغير.

وسنعالج هذه الحالات في مسائل ثلاثة؛ فنخصص الأولى لتصرفات الفضولي في مال

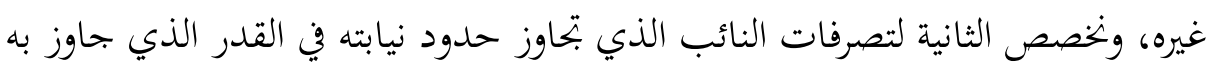

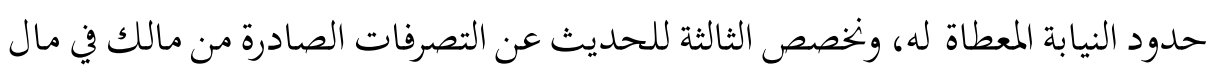

(1 (1 N / ) مصادر الحق، للسنهوري (1). 


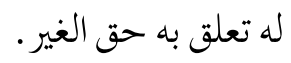

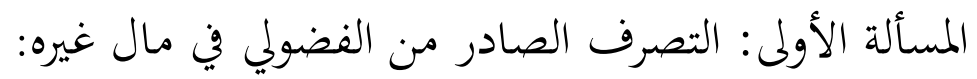

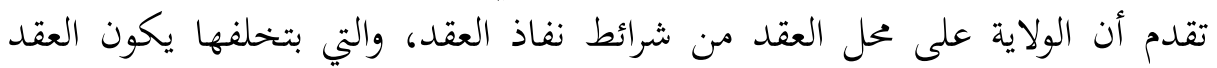

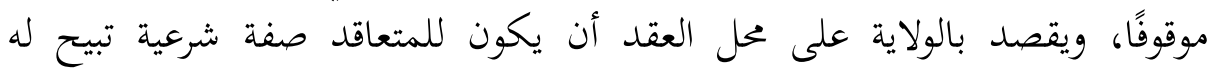

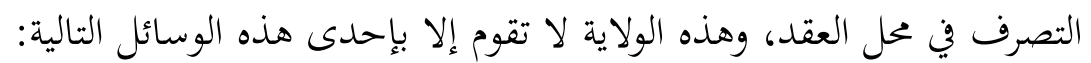

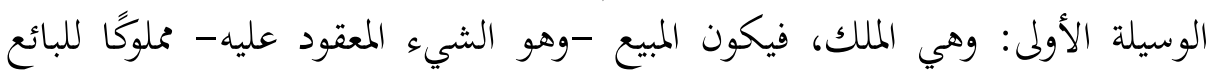

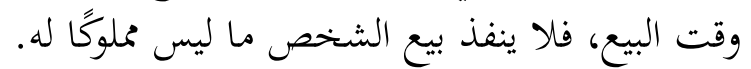

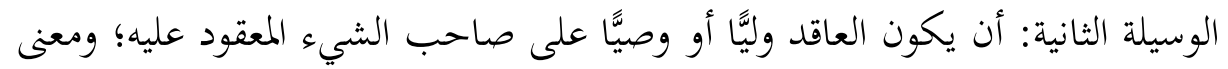

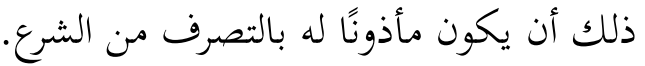

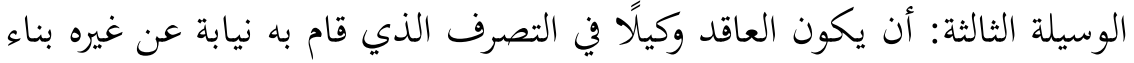

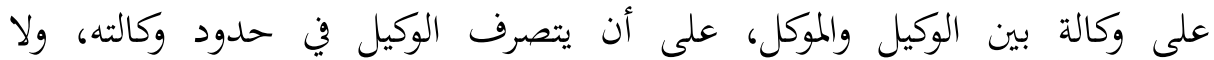

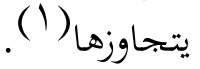

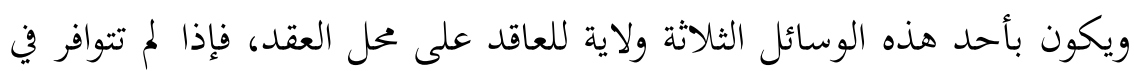

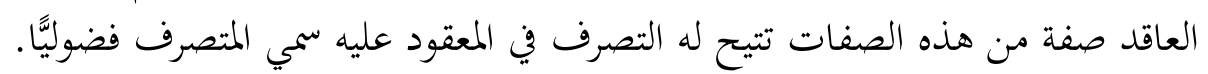

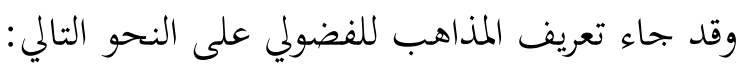

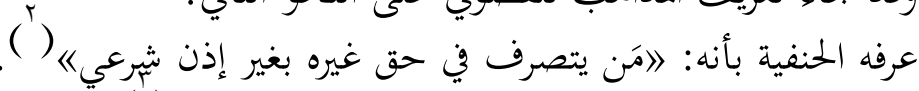

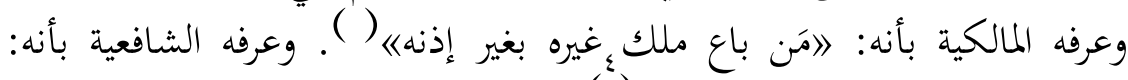

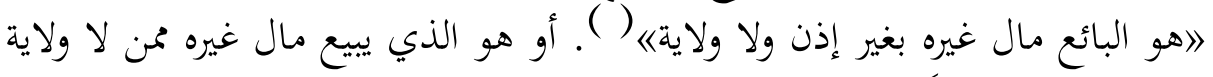

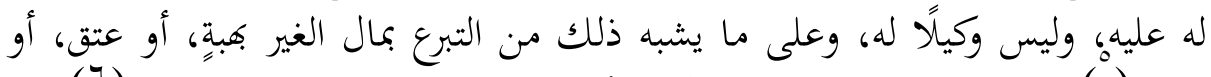

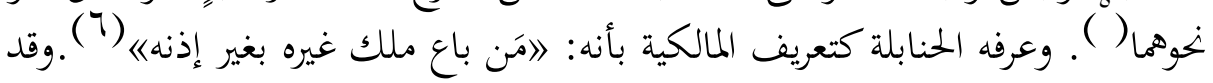
(1) ينظر: مصادر الحق، للسنهوري (ع VN/)، العقد الموقف، لعبد الرزاق فرج حسن، ص

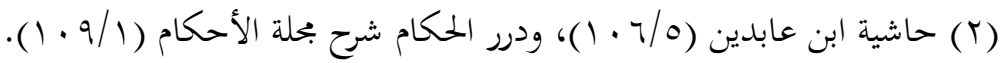

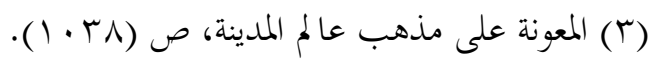

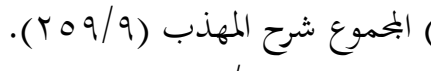

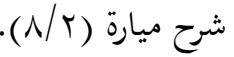

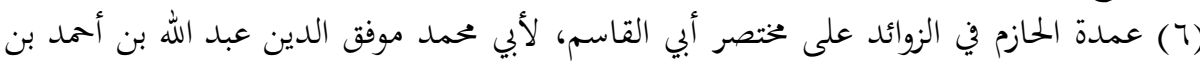

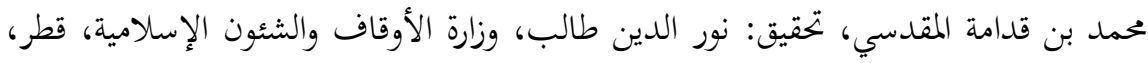
ط 


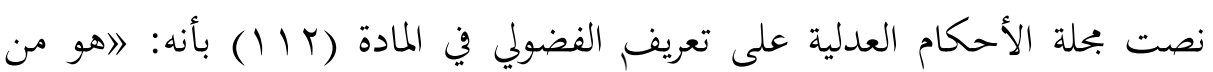

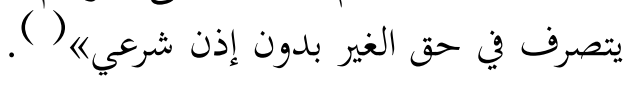

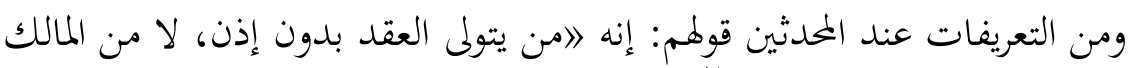

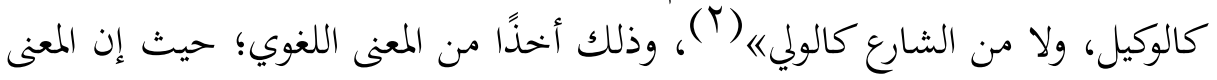

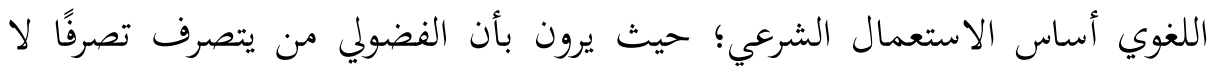

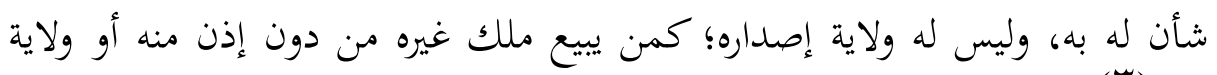
عليه (r) (بأن)

ونخلص من ذلك إلى أن التعريفات التي قال بها الفقهاء وإن كانت مختلفة في

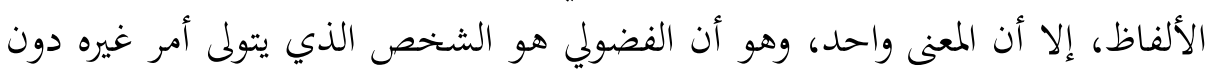
ولاية ولا إذن، ويتصرف فيه سواء كان ذلانك اللك بيعًا أو إيجارًا أو رهنًا.

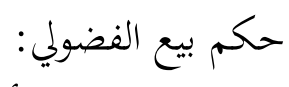

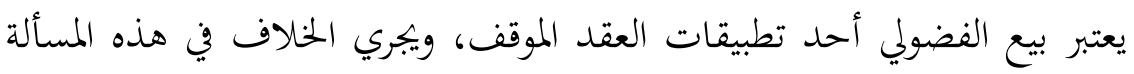

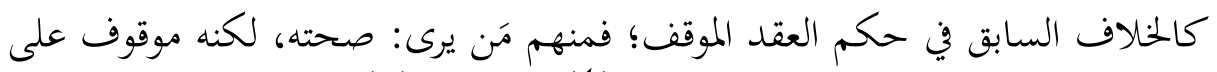

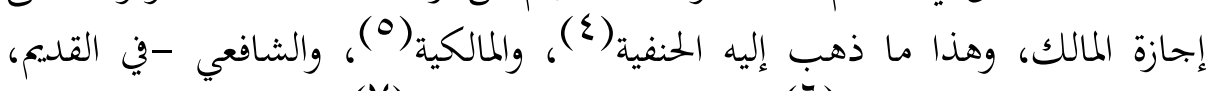

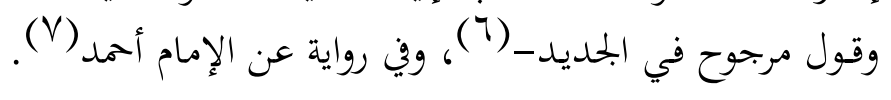

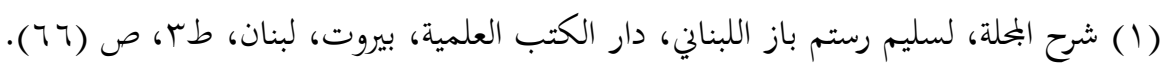

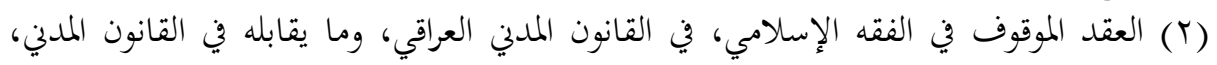

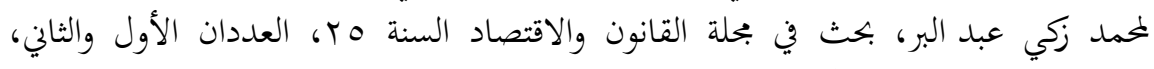

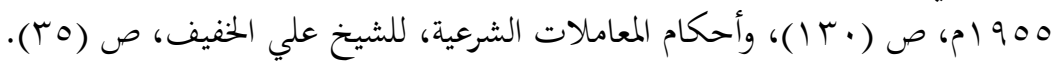

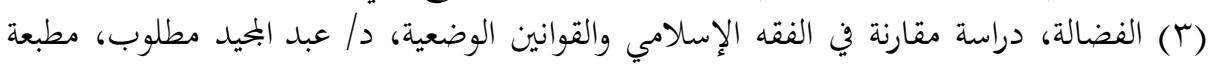
نيفرتيني، ص (؟ (T).

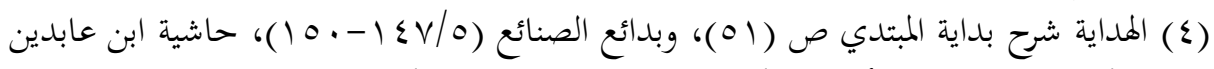

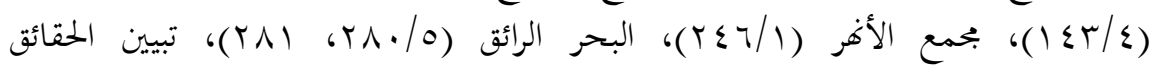
( (1) $r / 0)$

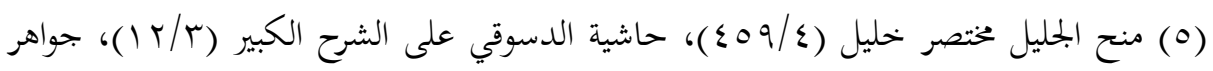

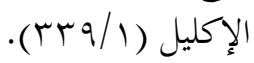

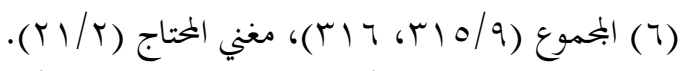

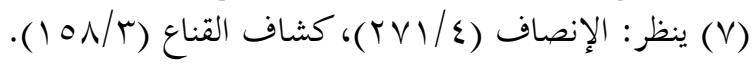




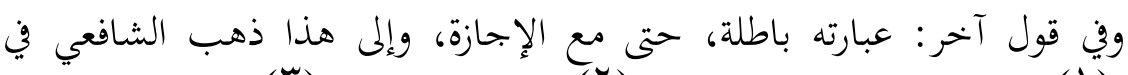

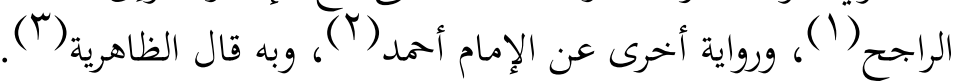

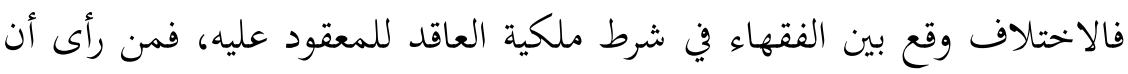

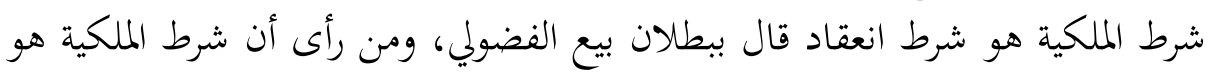
شرط نفاذ قال بصحة العقد موقوفًا على إجازة المالك.

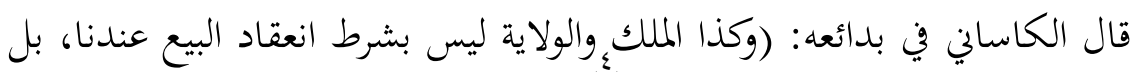
هو شرط النفاذ حتى يتوقف بيع الفضولي) ( ).

المسألة الثانية: التصرف الصادر من النائب الذي تجاوز حدود نيابته في القدر

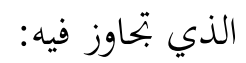
يتعين لترتيب النيابة لآثارها أن يكون للنائب سلطة النيابة عن الأصيل، وهذا

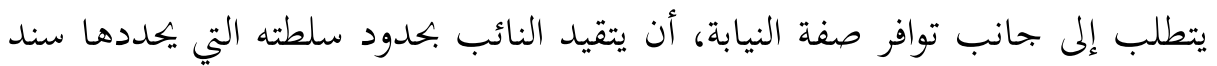

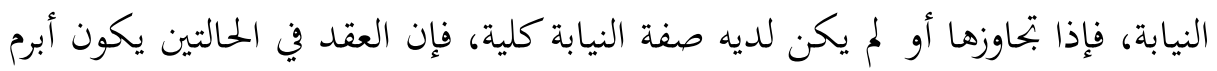

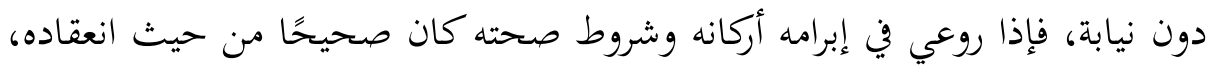

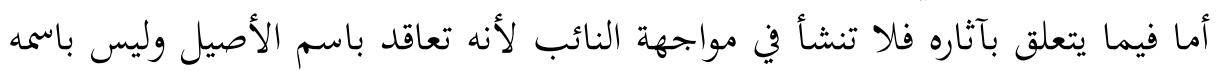

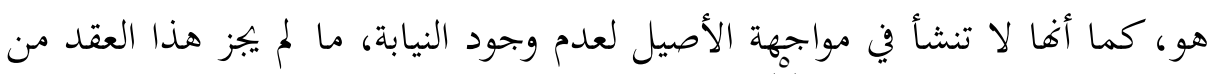
قبل من له سلطة إبرامه أصلًا ( ).

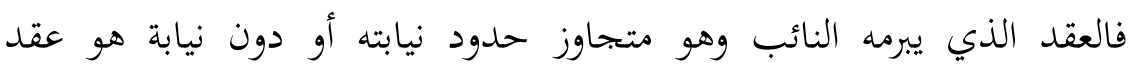

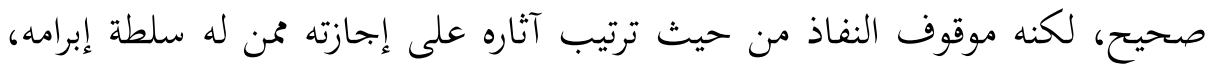

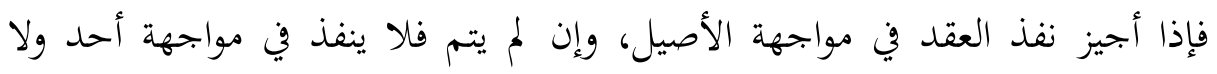

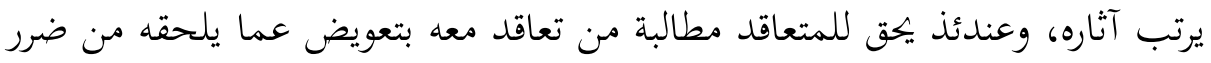

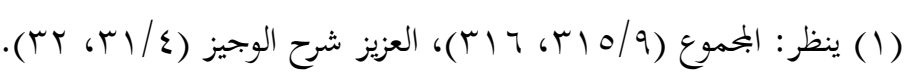

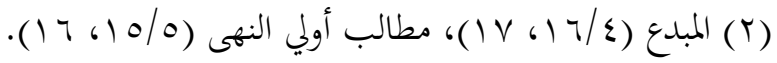

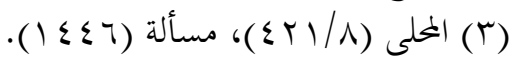

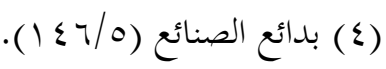

(0) نظرية الالتزام، المصادر الإرادية للالتزام، العقد والإرادة المنفردة في القانون الكويتي، د/ إبراهيم

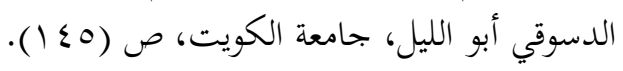




$$
\text { في تفويت الصفقة عليه( ') }
$$

وقد فصل الفقهاء مخالفات النائب حدود نيابته، سواء كانت مخالفاته تعليمات الأصيل في صفة الشيء المكلف بشرائه أو في جنسه أو مقدراه أو ثمنه، أو كانت

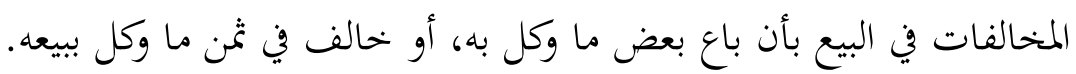

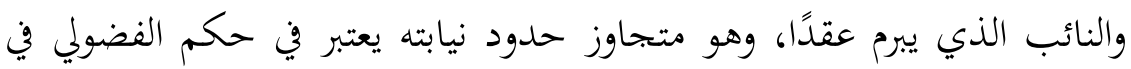

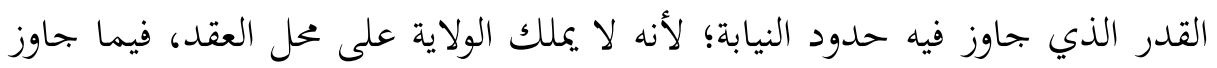

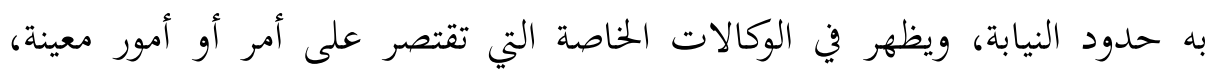
فليس للوكيل إلا مباشرة الأمور المعينة فيها. فالخلاف الفقهي في تجاوز النائب حدود نيابته مبني على تصرفات الديات الفضولي، فالقائلون بصحة ووقف تصرفات الفضولي يصححون تصرفات النائب مع وقفها على النى

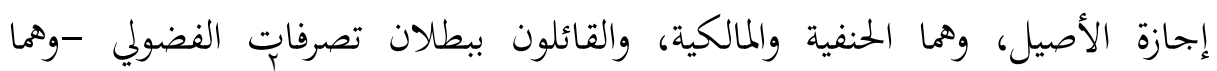

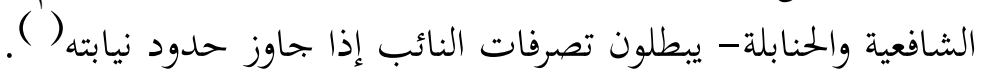

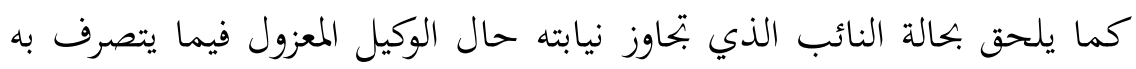

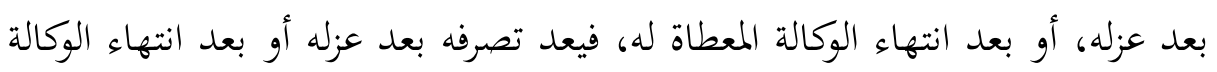
المعطاة له، بحكم تصرف الفضولي.

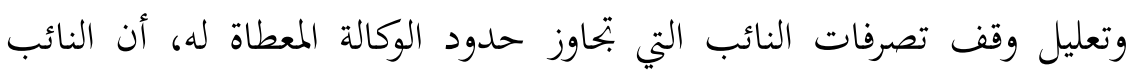

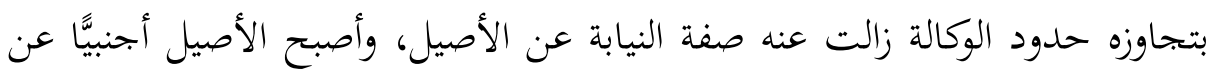

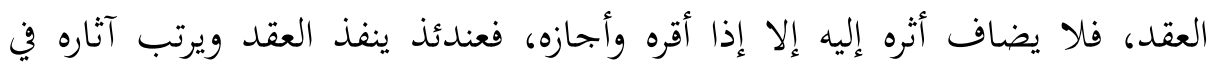

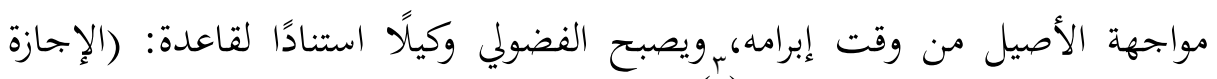
اللاحقة في حكم الوكالة السابقة) ( ). وبتحر الإشارة إلى أن تصرف الفضولي يفترق عن تصرف النائب الذبة الذي بتحاوز

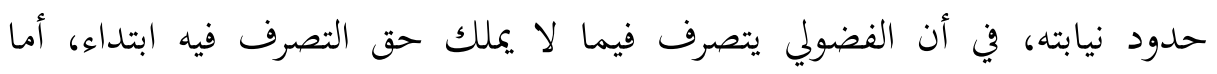

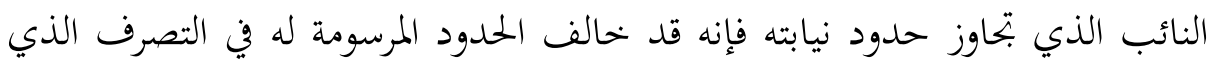
حق له مباشرته ابتداء. 
المسألة الثالثة: التصرف الصادر عن مالك في مال له تعلق به حق الغير:

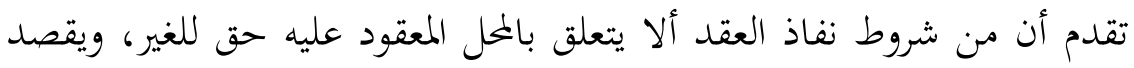

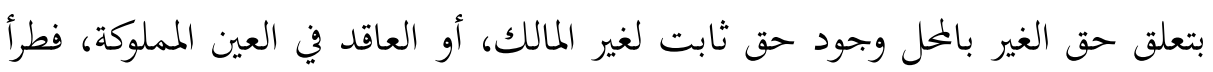

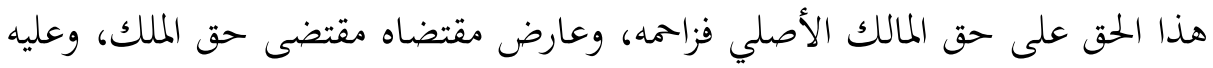

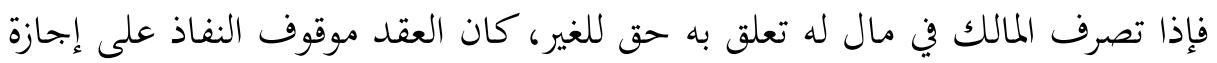

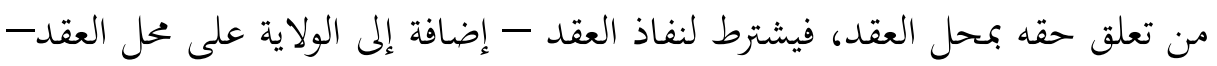

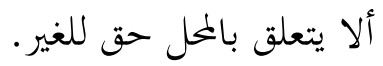
وتتعدد الحالات التي يتعلق حق الغير بالمل المعقود عليه، وذلك على عدة صور:

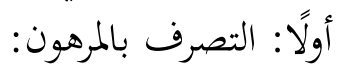

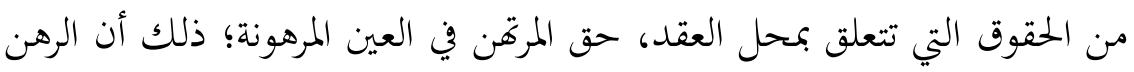

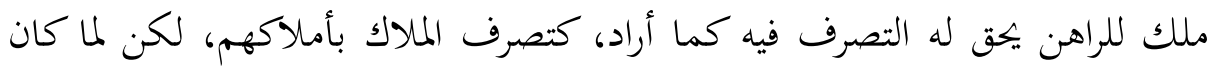

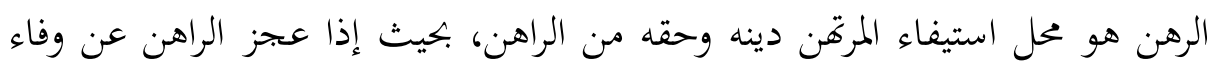

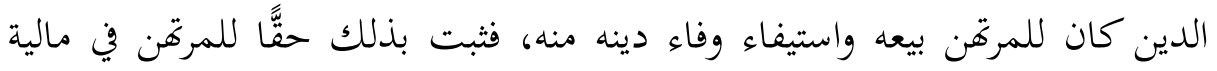

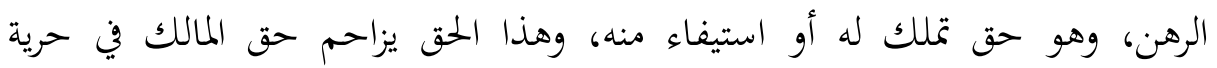

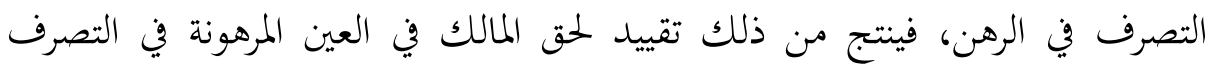

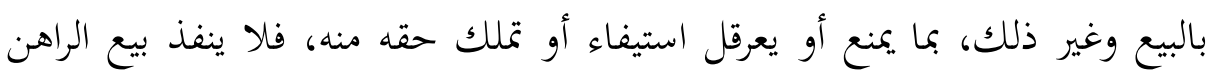

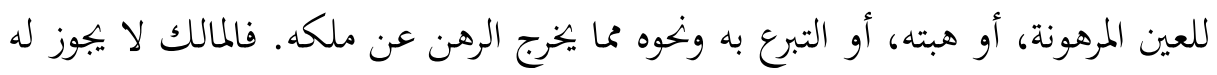

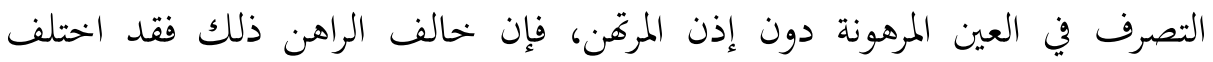
الفقهاء في حكم هذا البيع على قولين: المونية

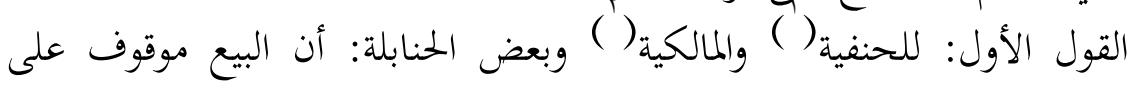

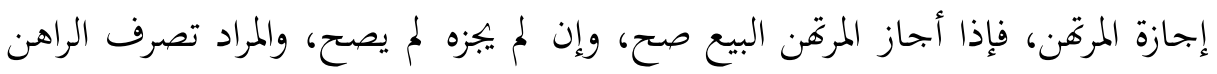

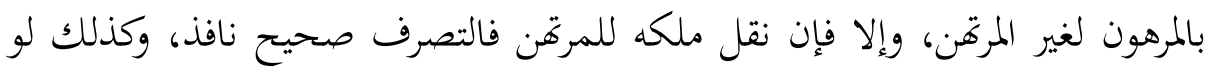

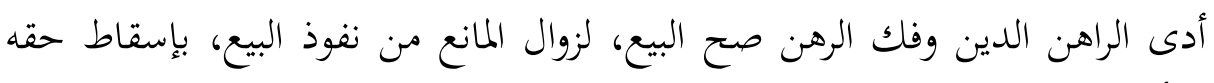

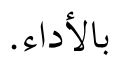

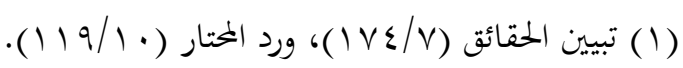

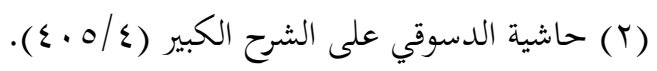


القول الثاني: للشافعية(' ) والحنابلة('): أن بيع الراهن للمرهون دون إذن المرتن باطل غير صحيح ولا نافذ، رغم كون البائع مالكًا للعين.

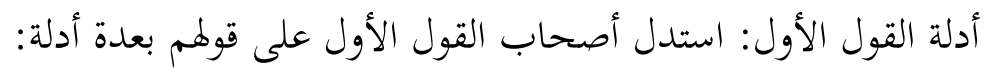

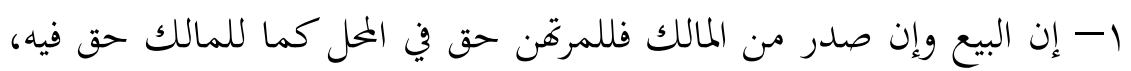

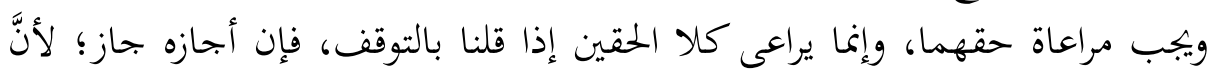

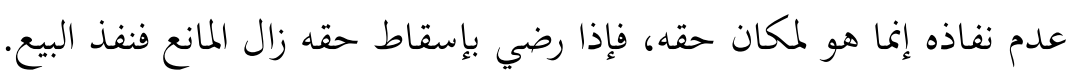

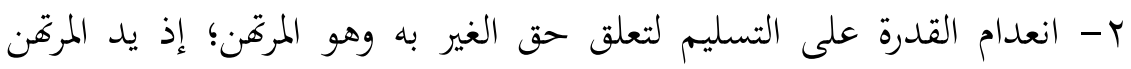

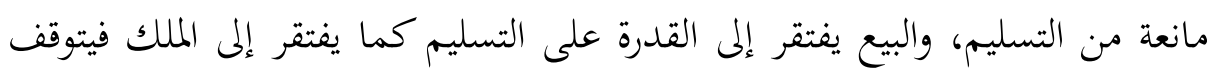
على إجازته.

r- القياس: وذلك بقياس بيع المرهون على الوصية بأكثر من الثلث، وذلك بأن

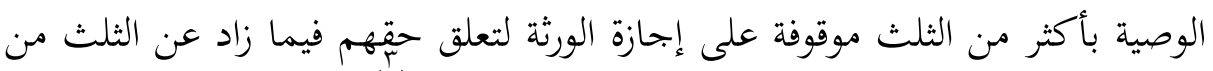

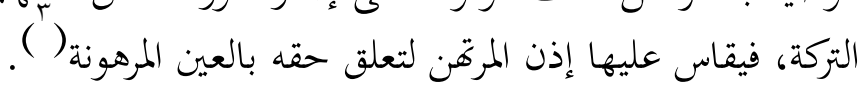
استدل أصحاب القول الثاني على قولمم بعدة أدلة:

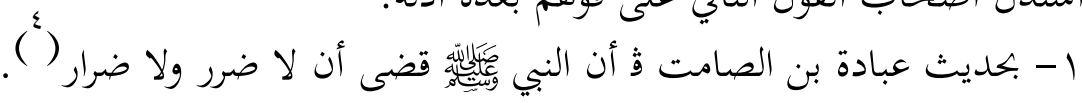

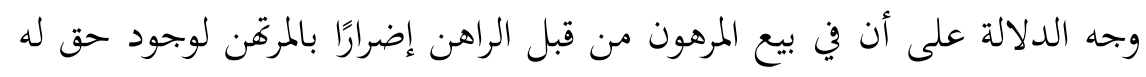

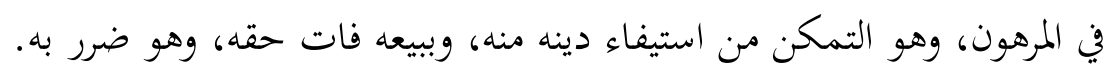

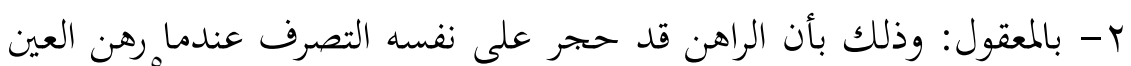

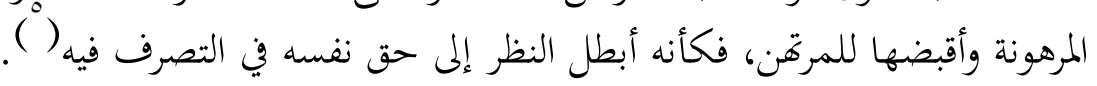
ثانيًا: بيع العين المستأجرة:

اختلف الفقهاء في بيع العين المستأجرة كاختلافهم في بيع المرهون؛ لتعلق حق المقان

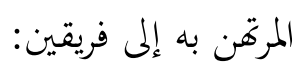

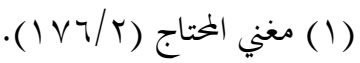

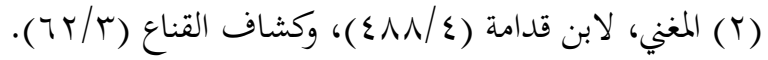

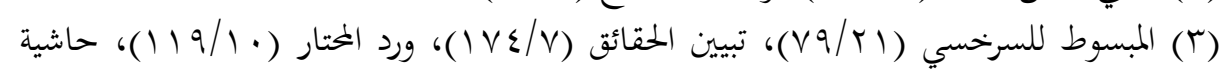

$$
\begin{aligned}
& \text { الدسوقي (ع / ا • ع). } \\
& \text { (؛) سيأتي تخريجه. }
\end{aligned}
$$

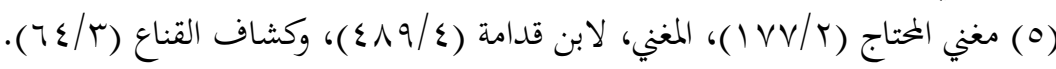




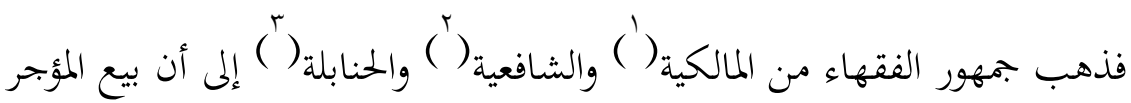

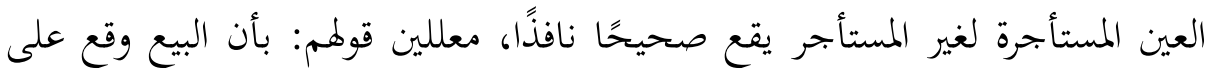

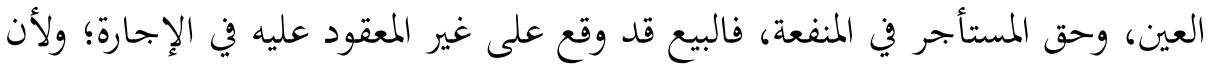

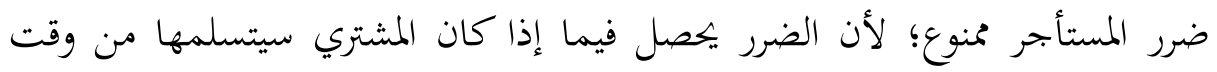

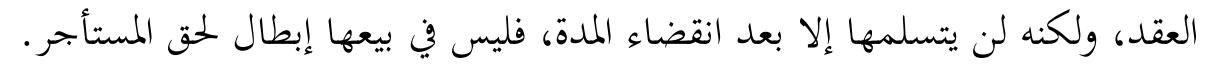

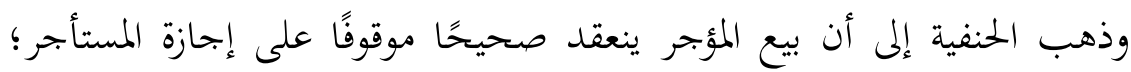

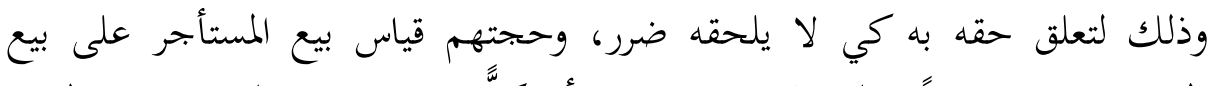

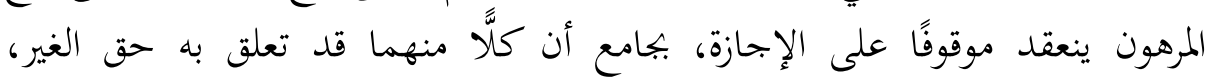

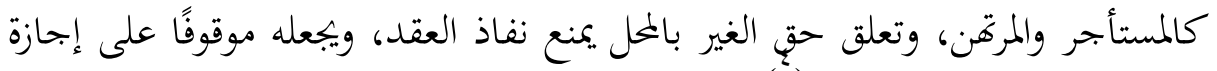

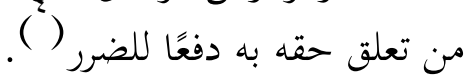
ثالثا: بيع الشريك حصته:

اختلف الفقهاء في حكم تصرف الشريك في حصة شائعة على قولين:

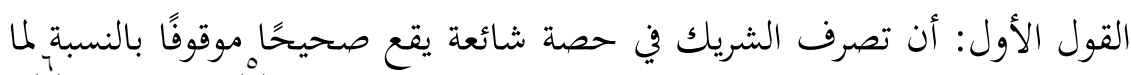

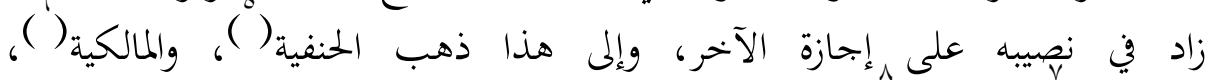

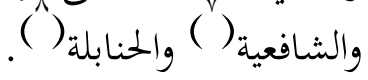

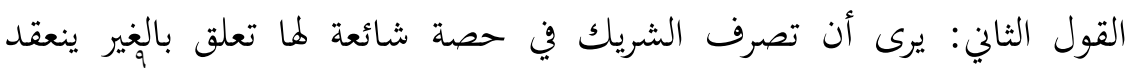

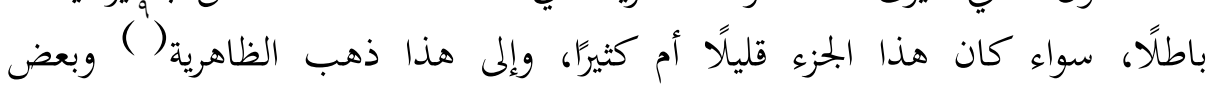

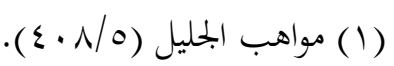

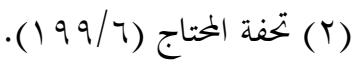

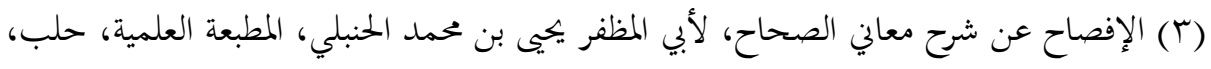

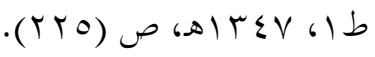

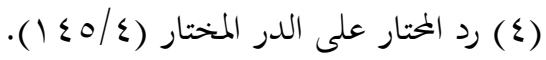

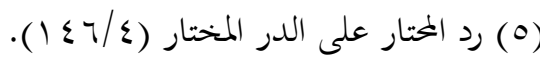

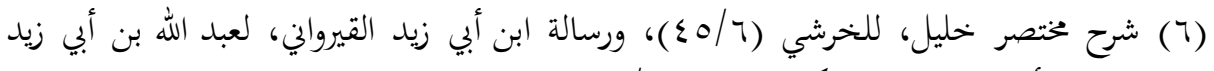

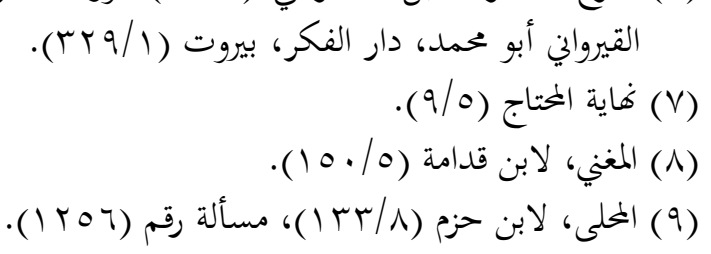


وقد نصت المادة (99 (1) من مرشد الحيران على أن: "لكل واحد من الشركاء في الملك أن يتصرف في حصته كيف يشاء بدون إذن شريكه بجميع التصرفات التي لا

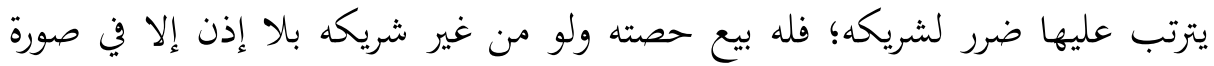

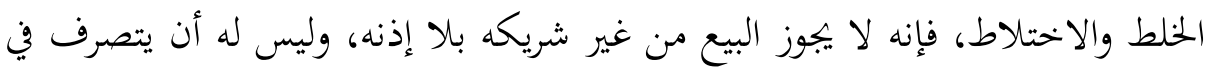

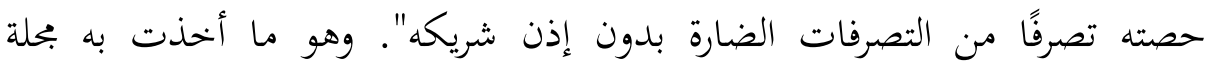

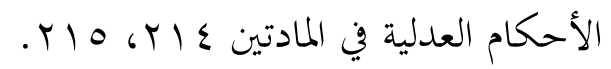

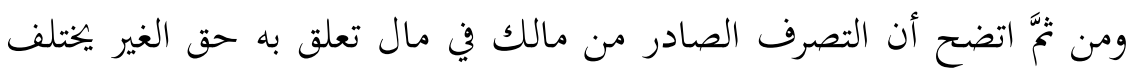
باختلاف العقد وطبيعته. الفرع الثاني: وقف العقد لانعدام الولاية على نوع التصرف:

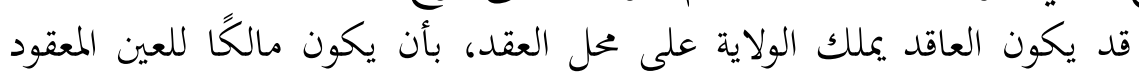

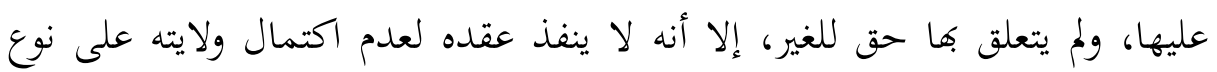

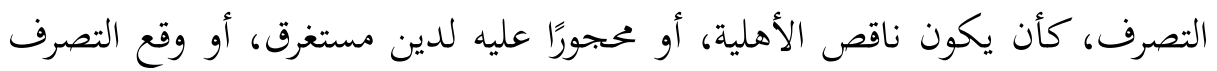

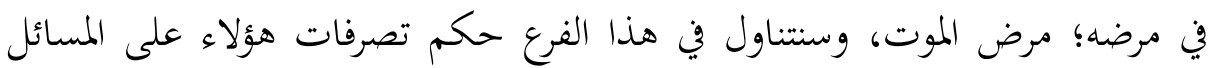
التالية:

المسألة الأولى: التصرفات الصادرة من ناقص الأهلية:

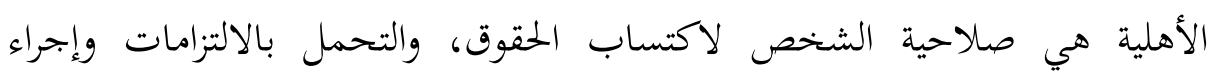

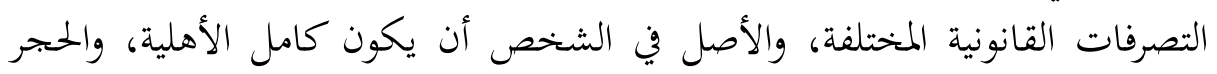

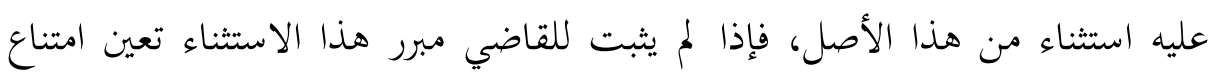

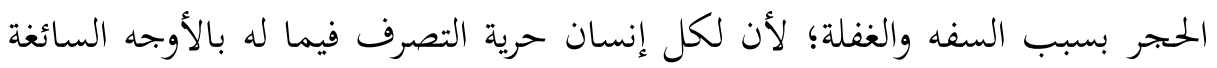

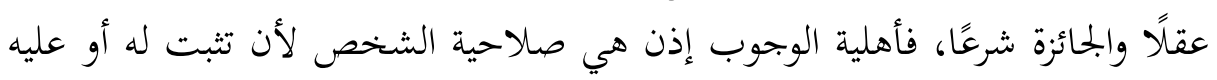

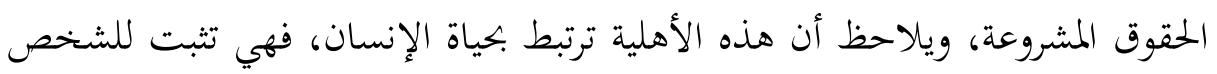

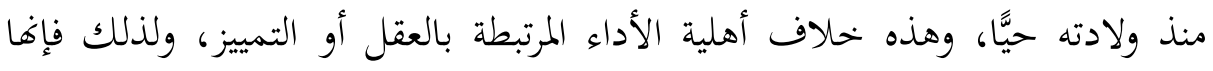

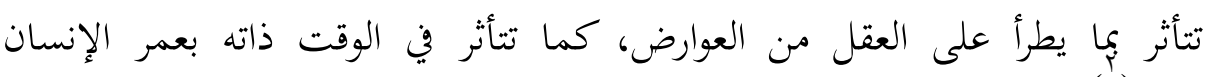


فناقص الأهلية: هو الشخص المميز، غير مكتمل العقل؛ إما لعدم بلوغه، ويطلق العقا

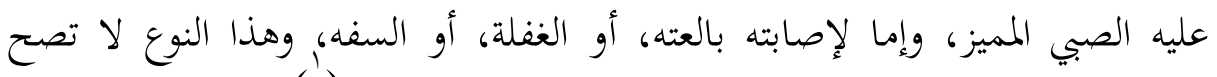

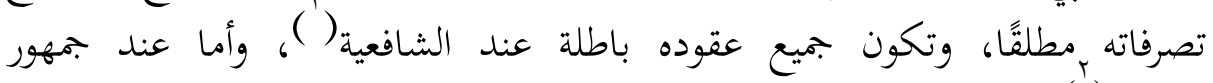

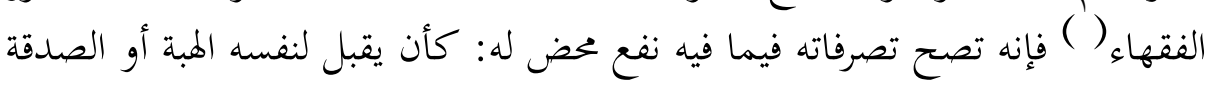

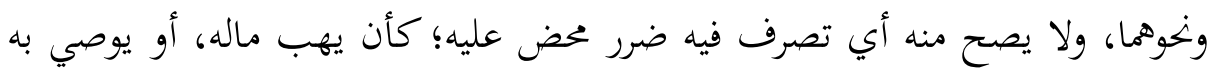

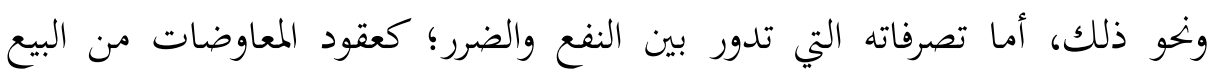

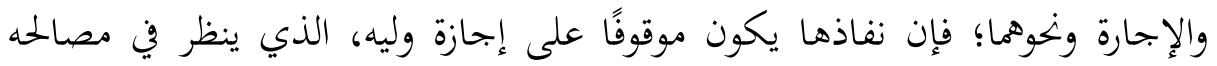
ويخفظ عليه ماله. المسألة الثانية: التصرفات الصادرة من المحجور عليه لدين:

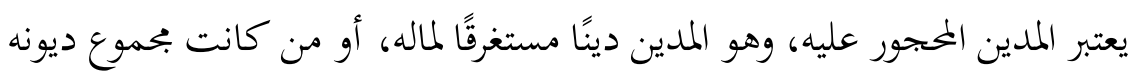

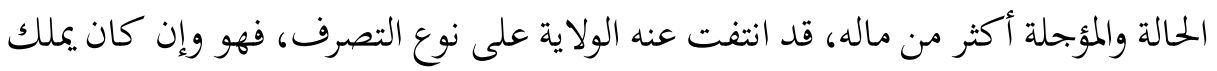

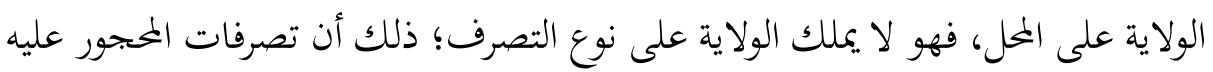

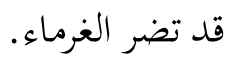
وقد اختلف الفقهاء في تصرفات المدين المحجور عليه على قولين:

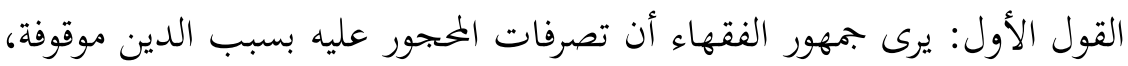

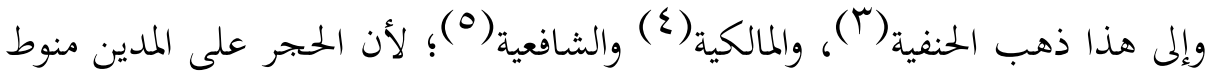

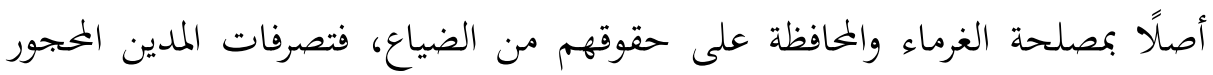

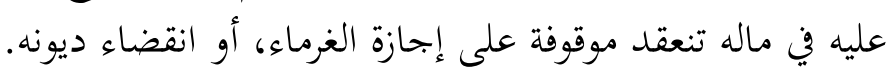

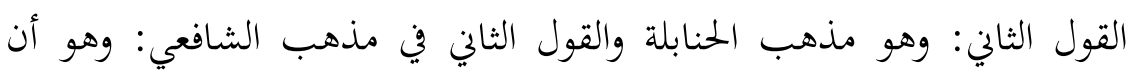

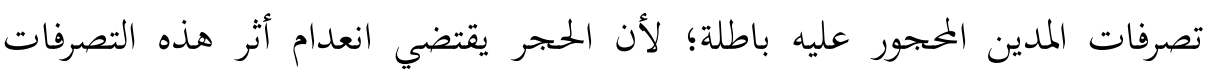

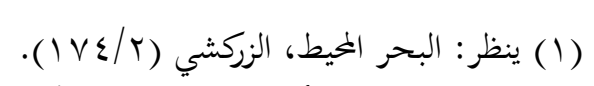

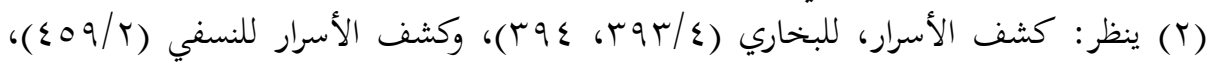

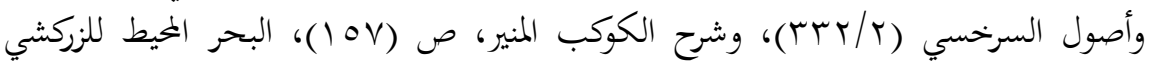

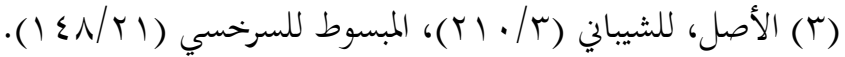

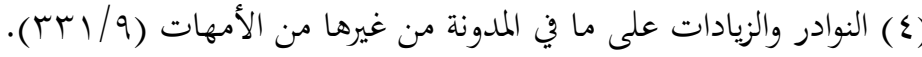

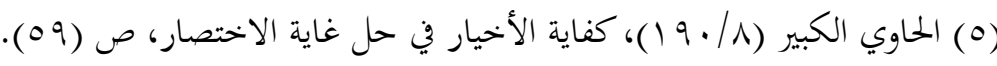


ابتداء، فلم يصح تصرفه فيها، ويعم ذلك جميع تصرفات المدين المحجور عليه، سواء

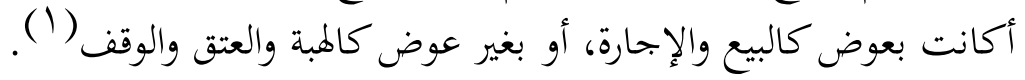

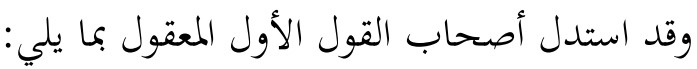

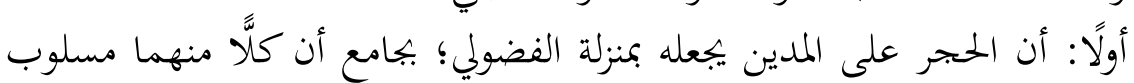

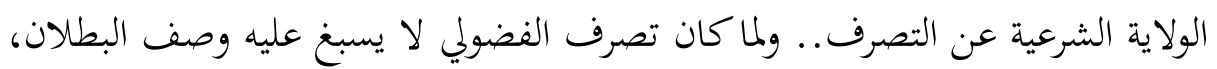
وإنما يسبغ عليه وصف الوقف فقط، كان ذلك أولى بالنسبة للمدين المحجور عليه.

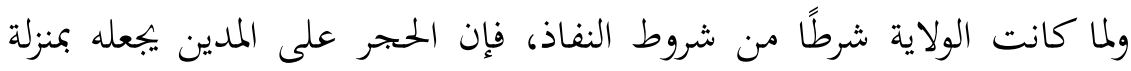

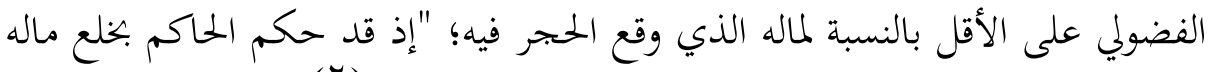

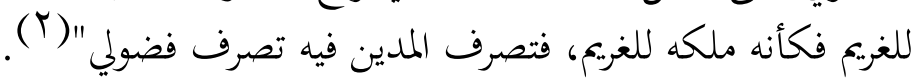

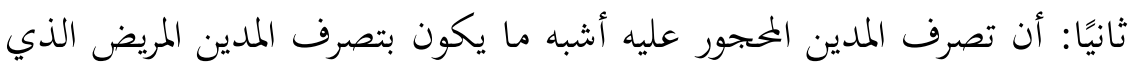

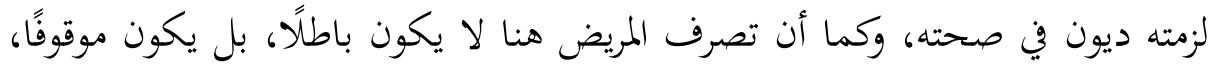

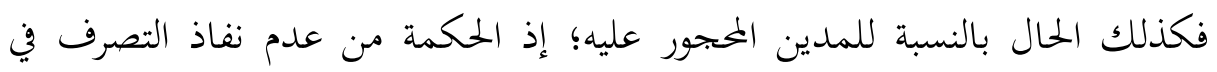

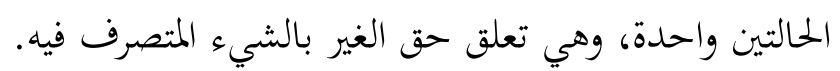

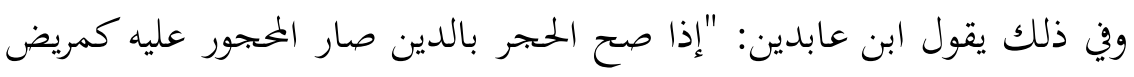

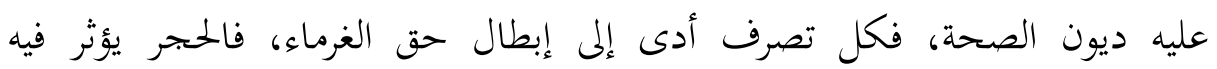

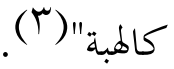
ثالثًا: أن تصرف المدين المحجور عليه كتصرف السفيه المحجور عليه، وبما أن

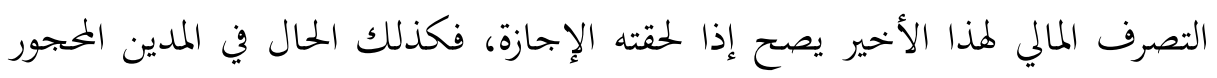

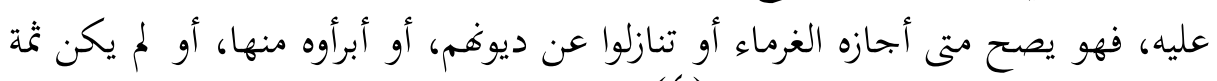

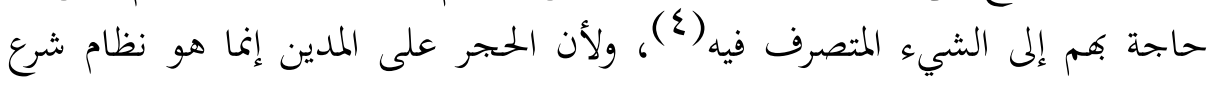

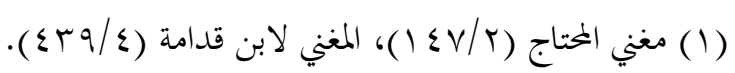

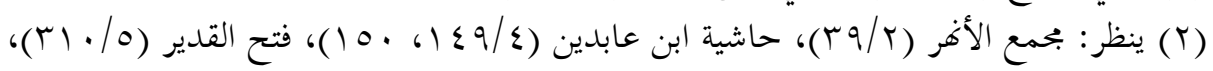

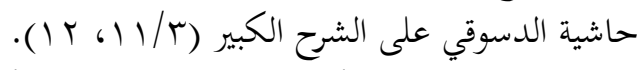

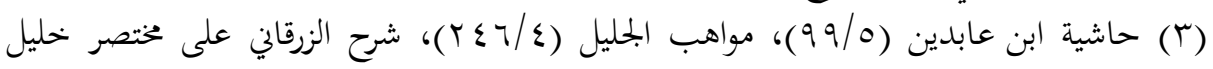

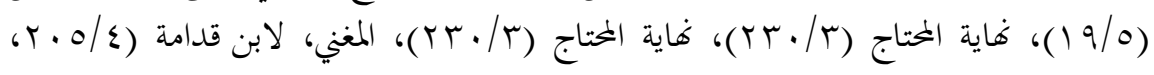


للضرورة، ولا ريب أن الضرورة تقدر بقدرها، وهذا القدر هو الذي يقتضي تأسيس الندا

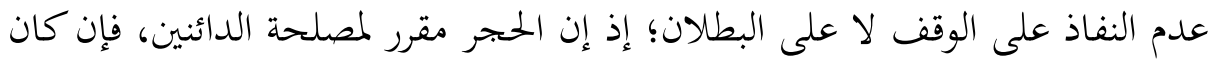

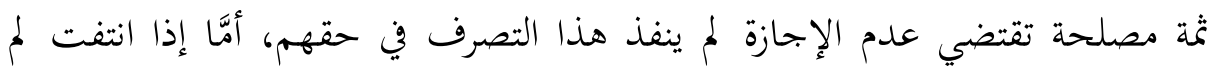

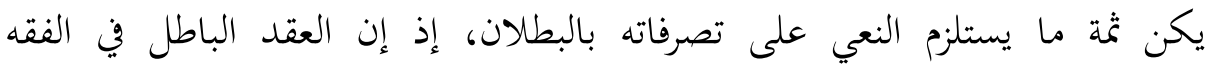

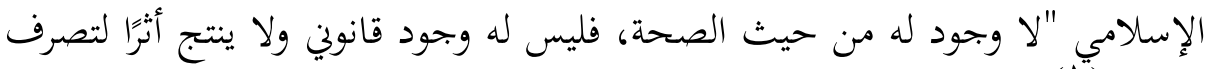
المسألة الثالثة: التصرفات الصادرة من المريض مرض الموت:

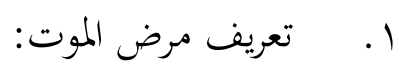

عَّرف الفقهاء المرض المخوف -مرض الموت- بعدة تعريفات على النحو الآتي:

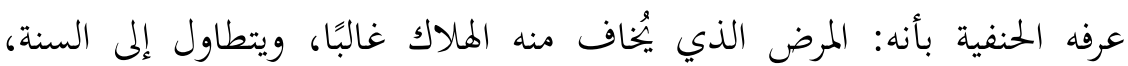

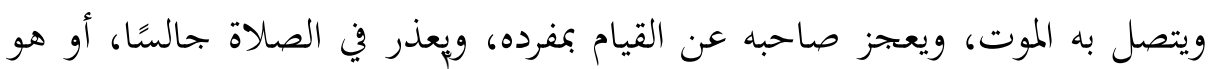

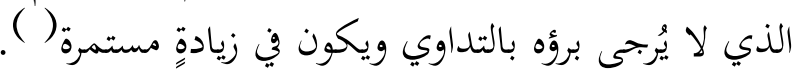

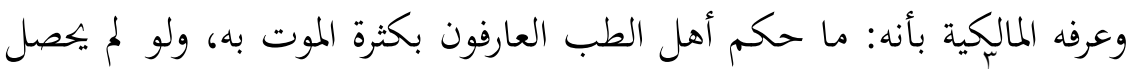

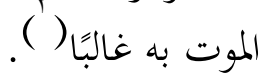
وعرفه الشافعية والحنابلة بأنه: المرض الذي يخاف منه الموت؛ لكثثرة مَن يموت به به بهات

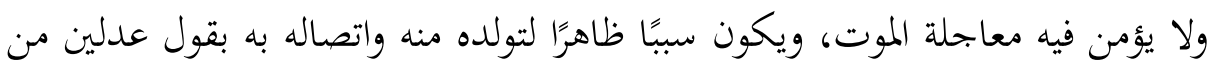

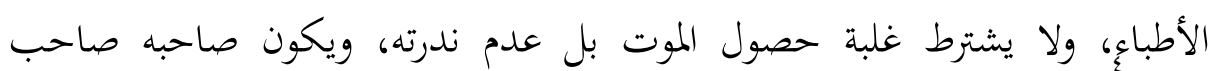

والمرض لا يؤثر في أهلية الأداء؛ لأنه لا يخل بالعقل، فيصح نكاح المريض وطلاقه ونه

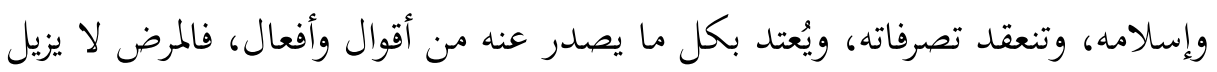

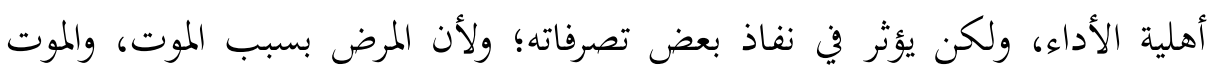

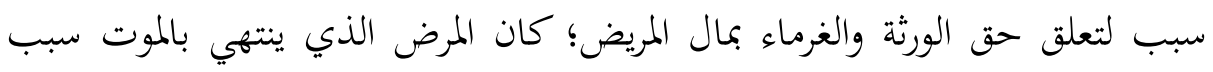

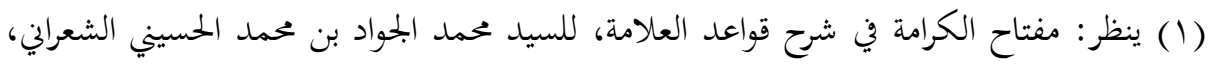

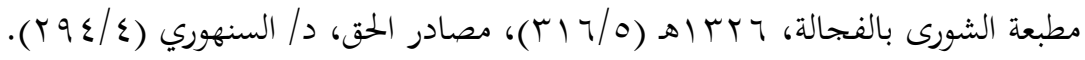

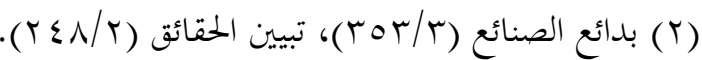

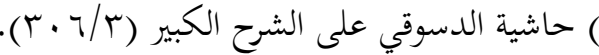

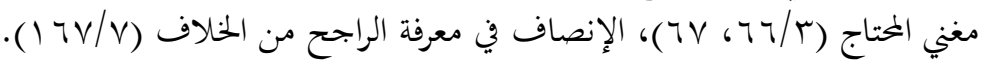


لتقييد تصرفات المريض التي تشتمل على محاباة تضر بالورثة أو الدائنين، وتقيد تصرفاته

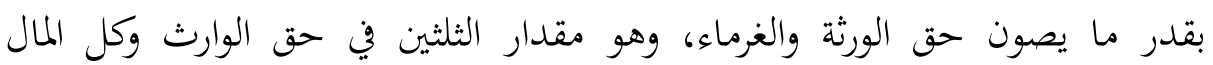

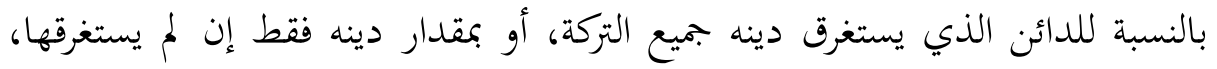

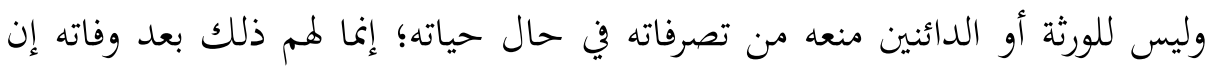

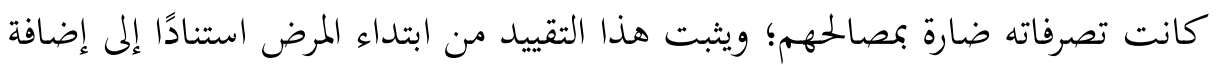

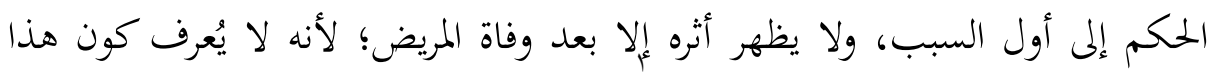
المرض مرض موت إلا إذا اتصل بالموت ألمات ( ).

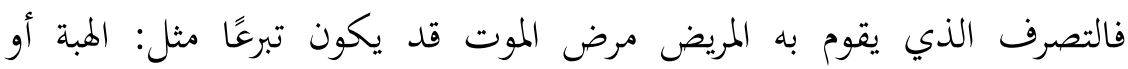

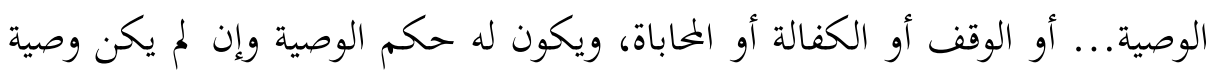

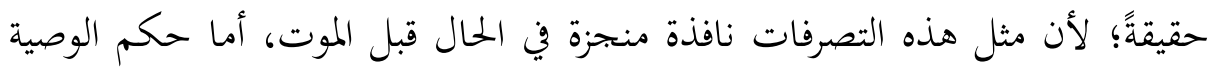

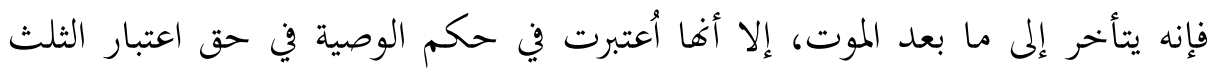

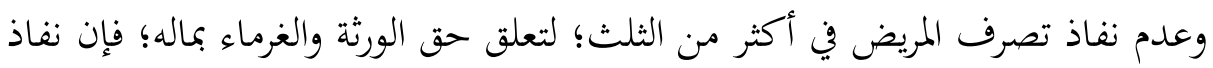

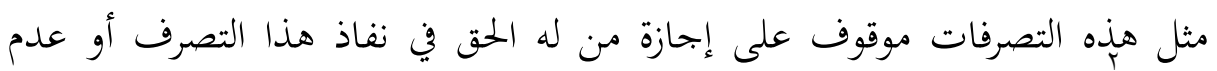
نفاذه ()

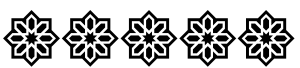

\section{المطلب الرابع : الآثار المترتبة على العقد الموقوف}

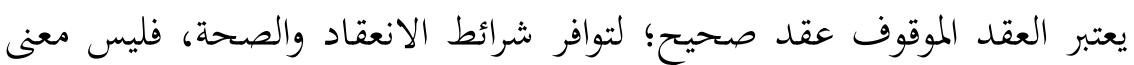

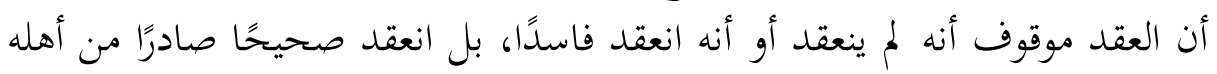

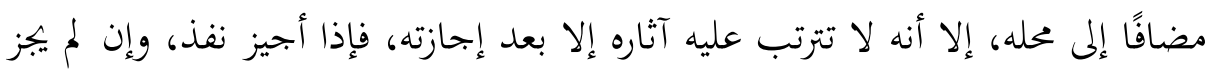

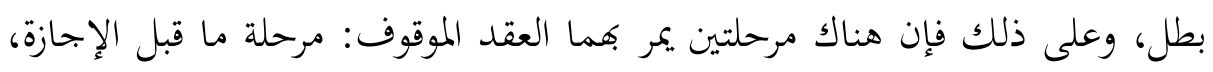
ومرحلة ما بعد الإجازة، وفيه فرعان: الفرع الأول: الآثار المترتبة قبل الإجازة:

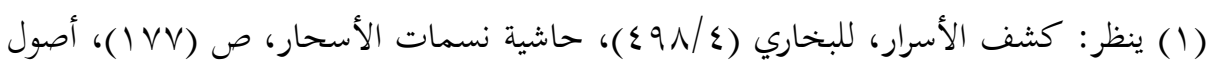

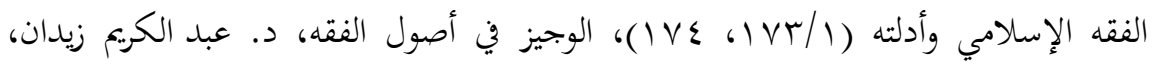

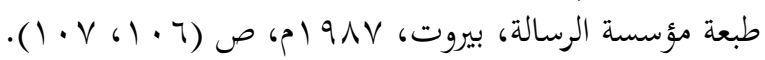

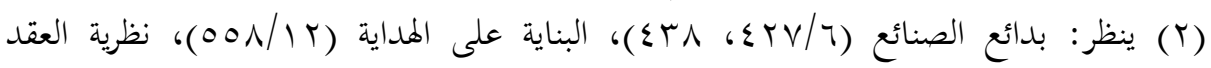

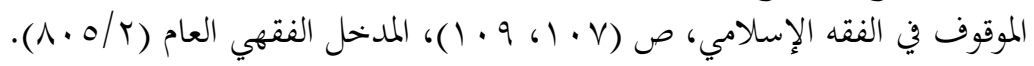


قبل أن تصدر الإجازة من يملكها، لا يظهر أثر العقد ويكون ظهور أثره موقوفًا

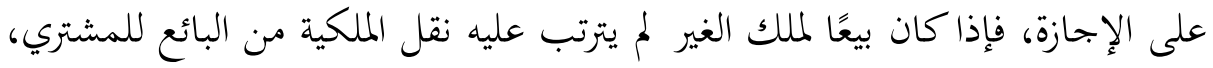

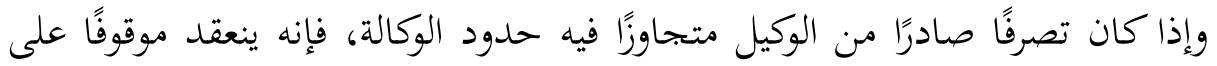

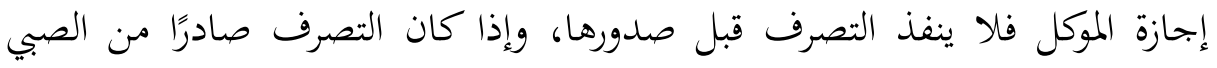

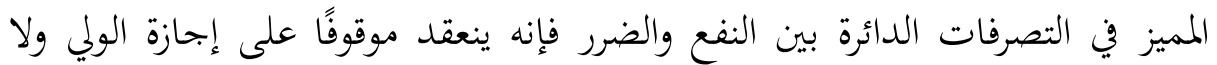

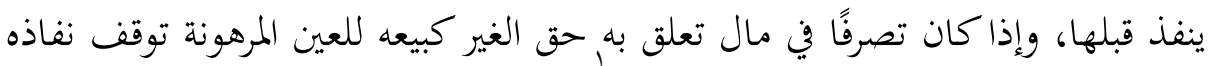
على إجازة المرتهن لتعلق حقه بالعين المبيعة ( ).

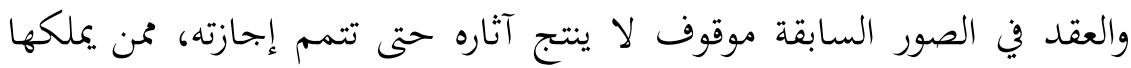
شرعًا.

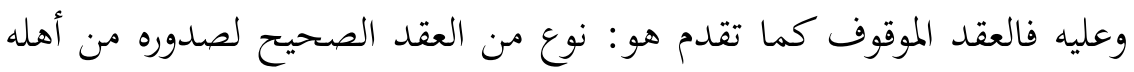

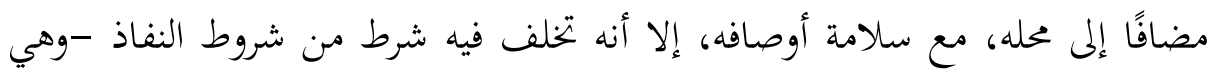

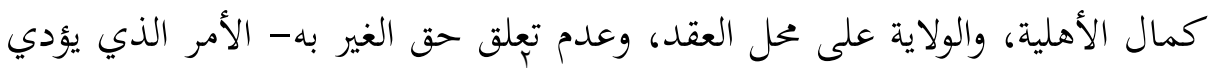

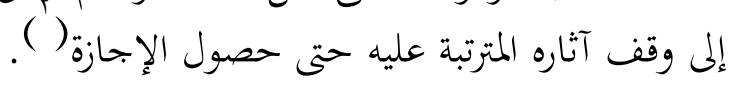

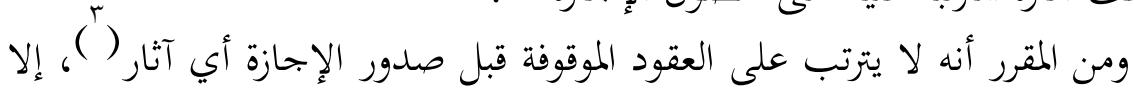

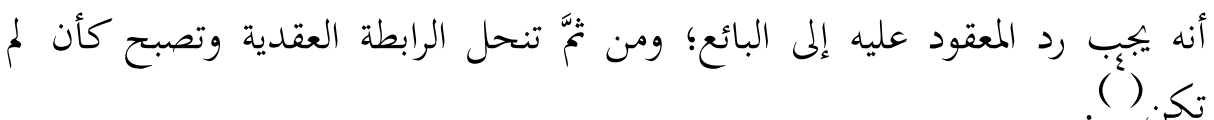
فإذا كان قائمًا ولم يتغير يرد بعينه كالمبيع إذا انفسخ البيع بسبب الفساد أو الإقالة أو الحيار أو الاستحقاق ونخوها. ففي هذه الحالات وأمثالها ترد العين المعقود عليها إلى صاحبها الأصلي، ويسترد

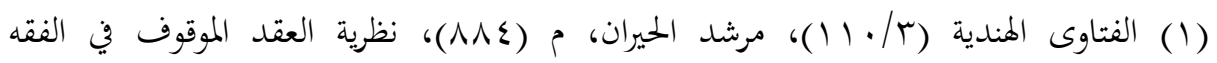

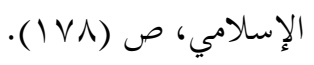

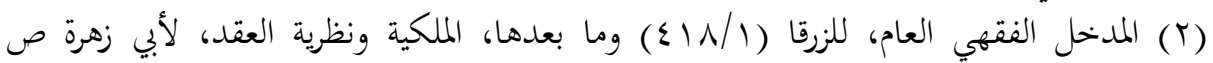

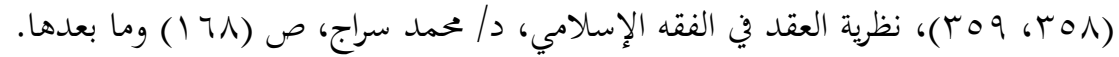

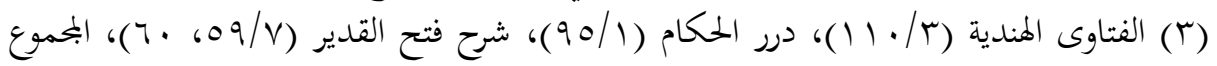

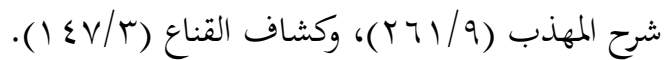

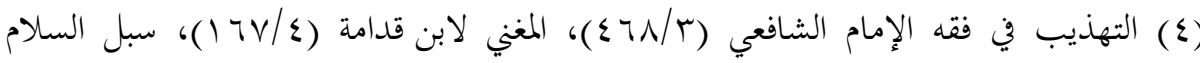

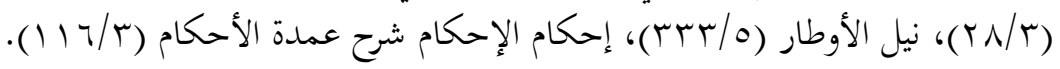




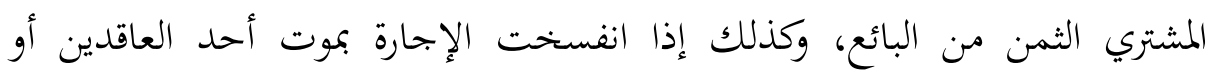

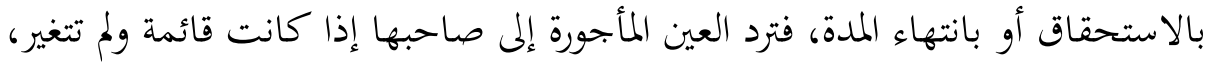

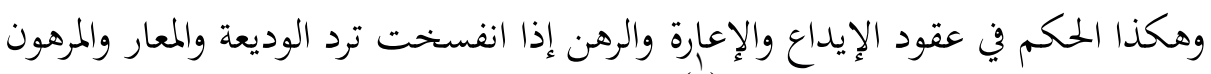

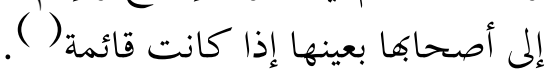

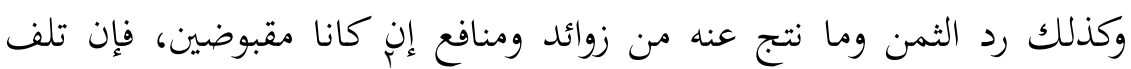

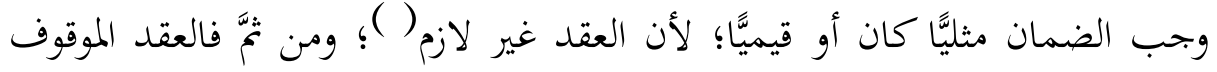

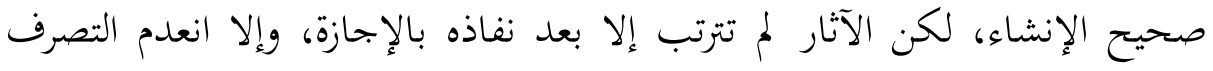

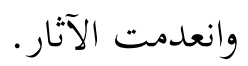

- الأحوال التي تطرأ على العقد الموقوف قبل الإجازة:

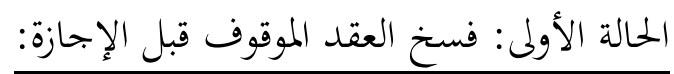

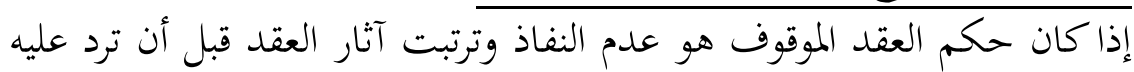

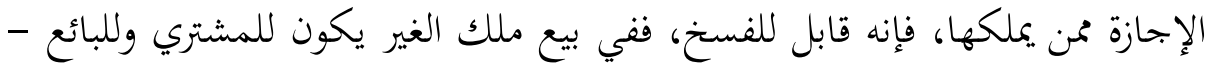

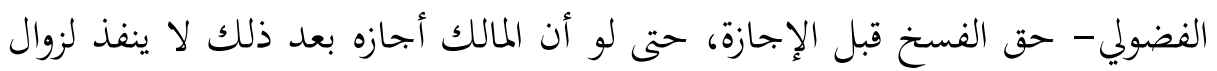

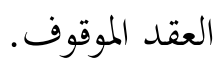

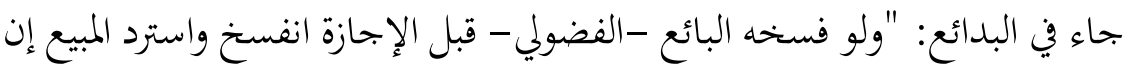

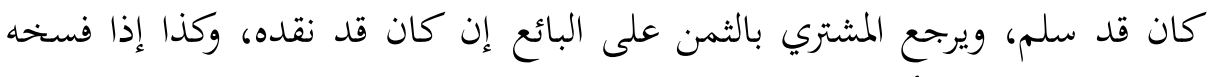

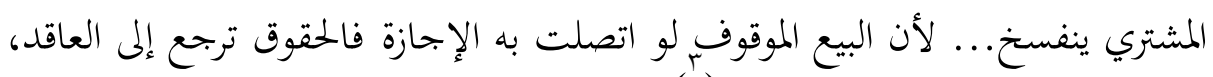

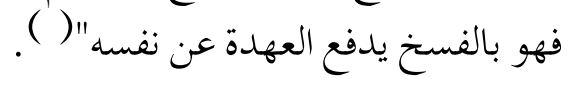

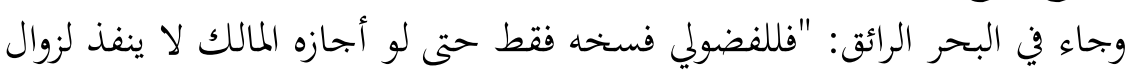

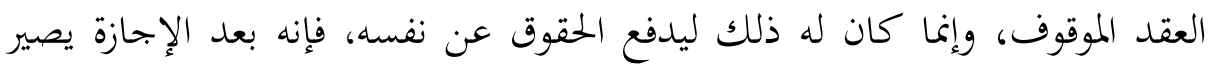

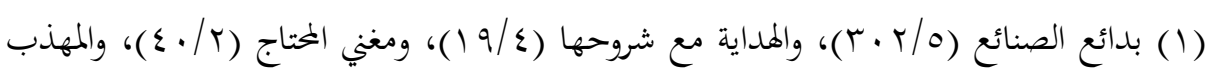

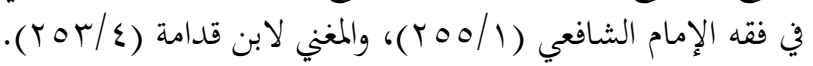

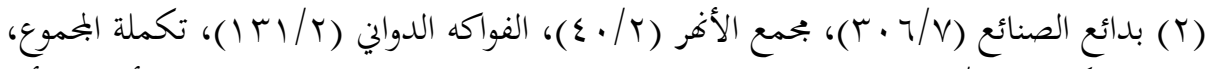

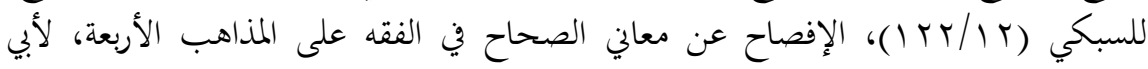

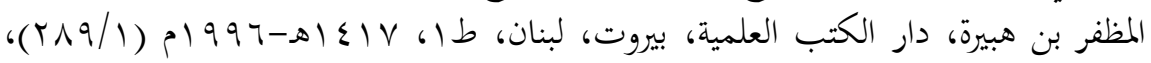

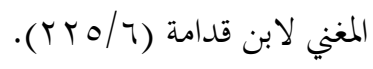

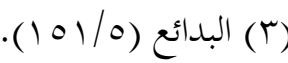


كالوكيل فترجع حقوق العقد إلبه، فيطالب بالتسليم ويخاصم بالعيب وفي ذلك ضرر به، فله دفعه عن نفسه قبل ثبوته" ( ).

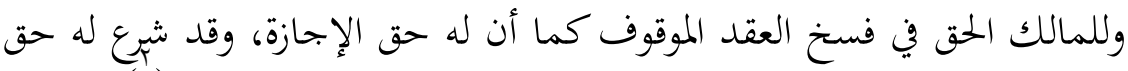

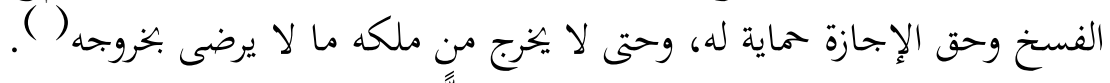

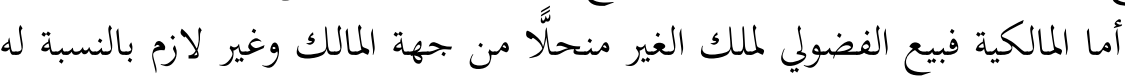

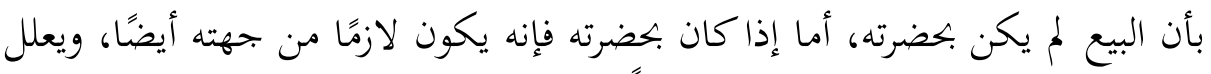

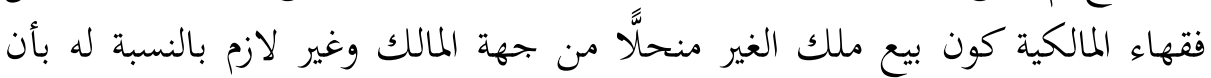

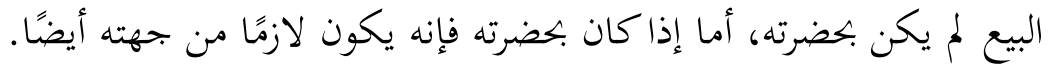

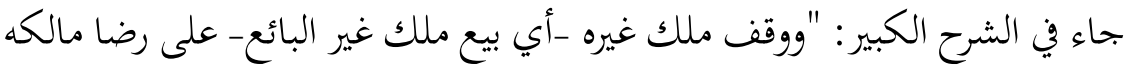

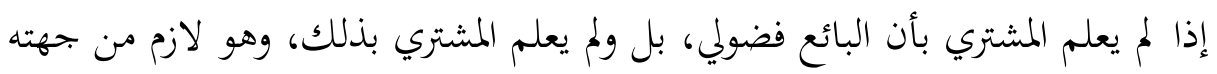

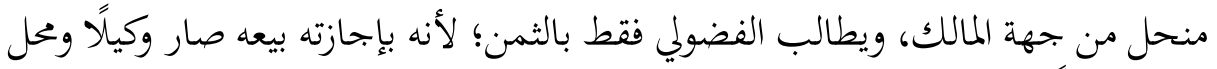

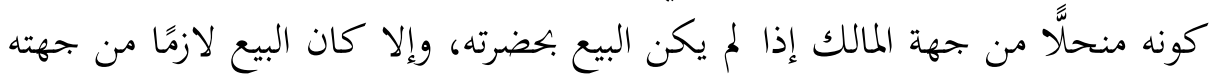

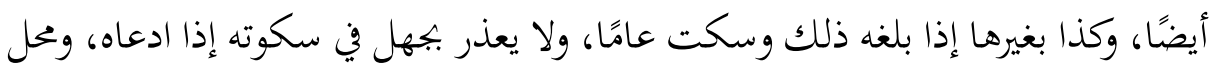

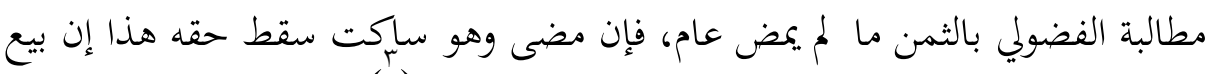

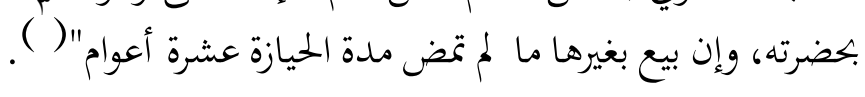

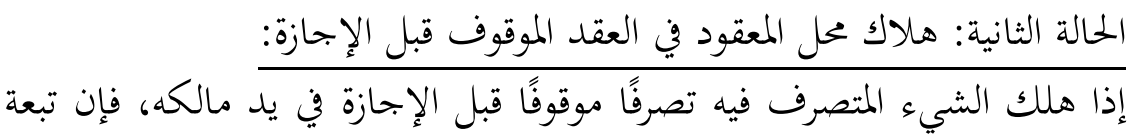

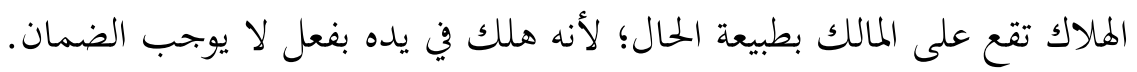

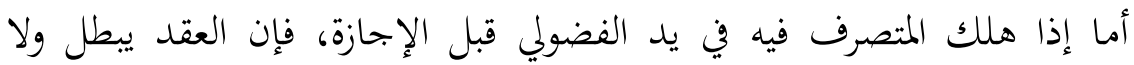

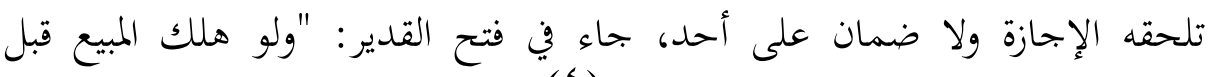

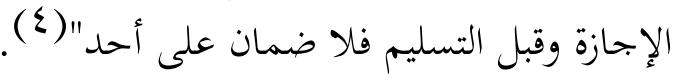

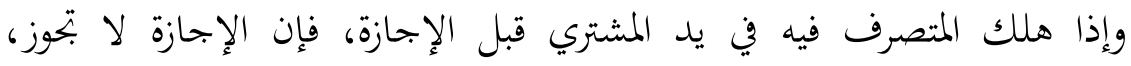

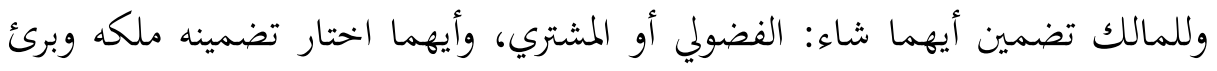

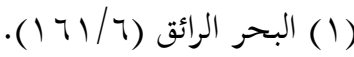

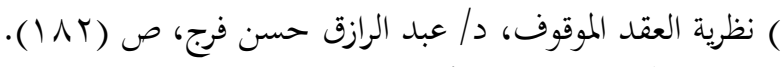

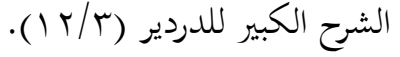

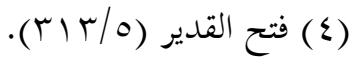




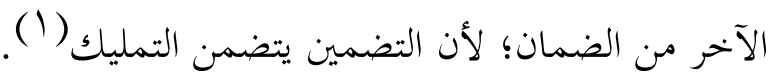

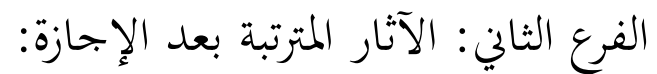

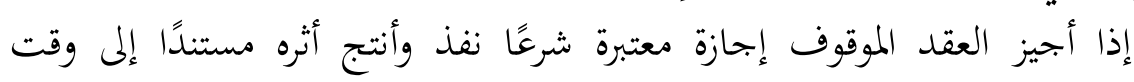

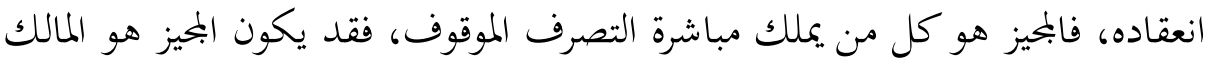

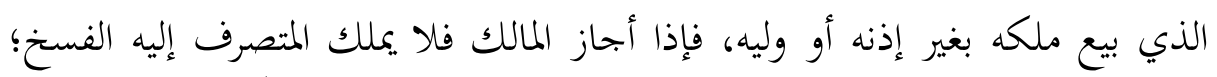

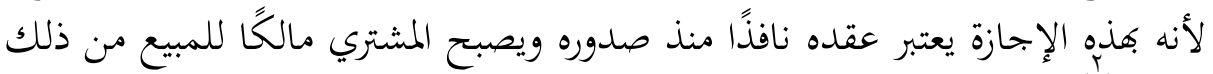

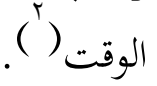
وتعرف الإجازة بأها تصرف من جانب واحد يصدر ممن له الحق في مباشرقا،

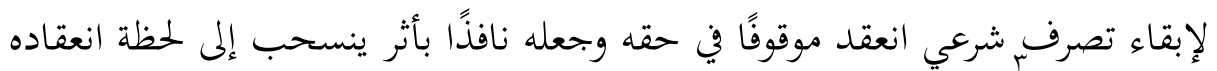

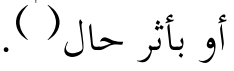

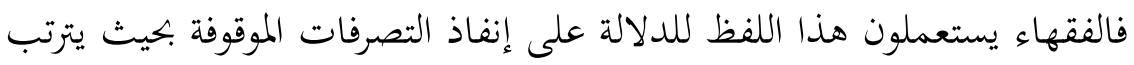

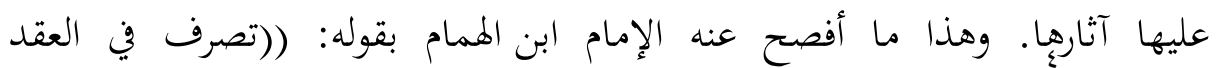

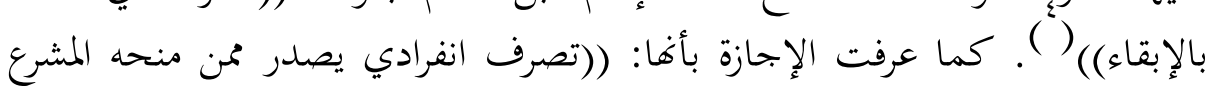

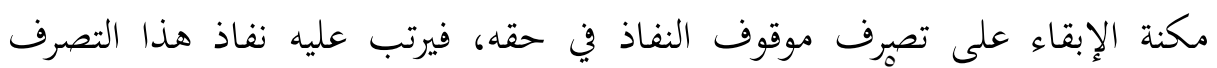

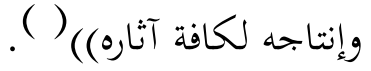

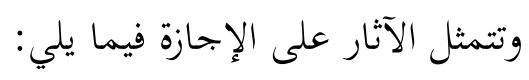

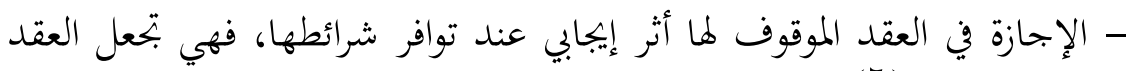

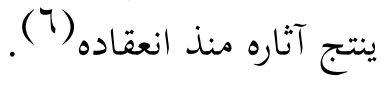

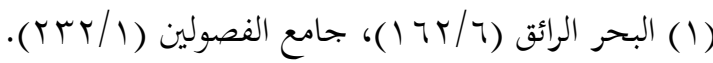

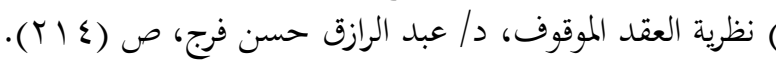

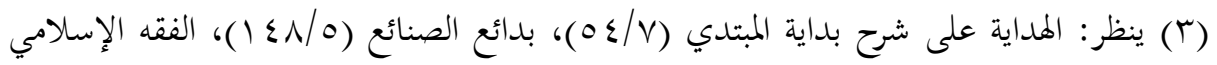

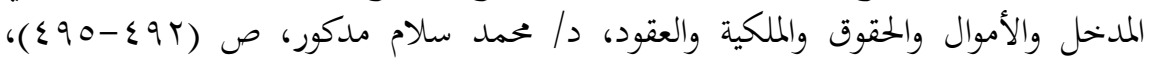

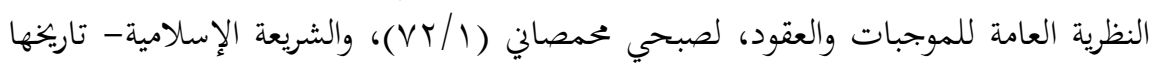

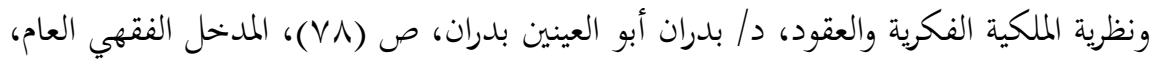

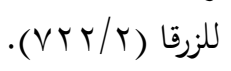

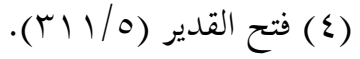

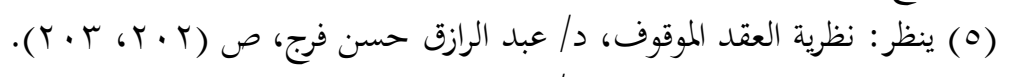

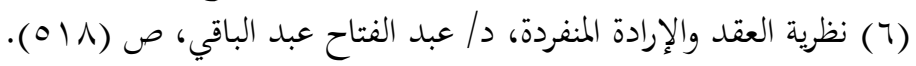




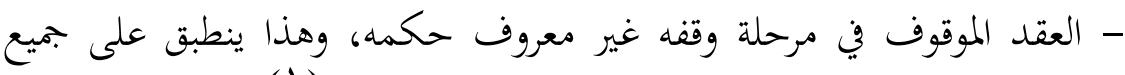

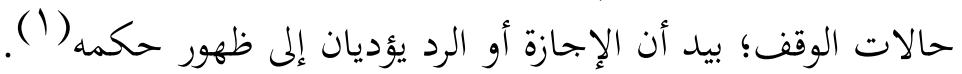

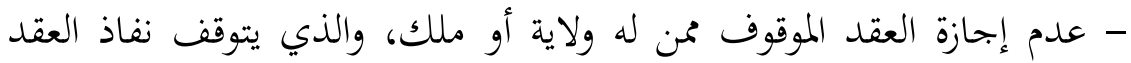

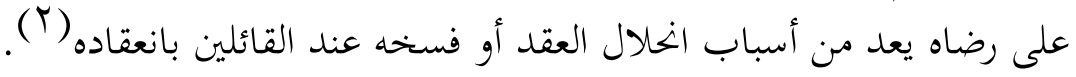

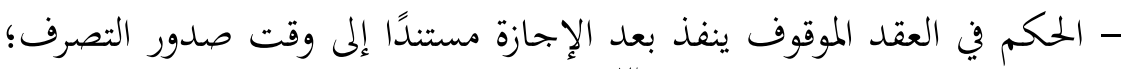

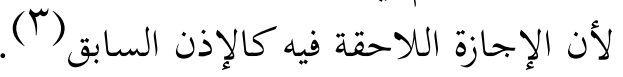

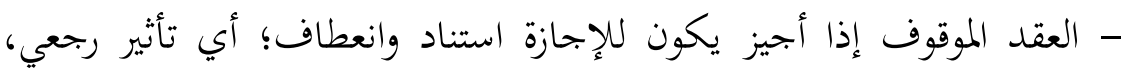

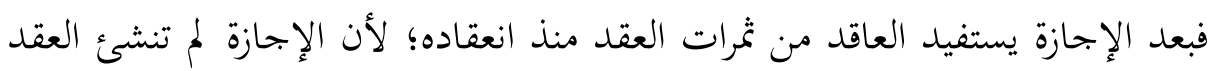

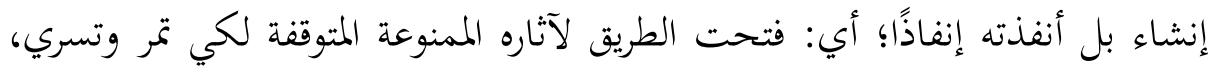

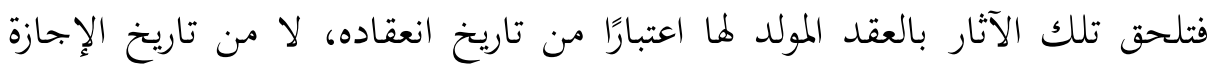

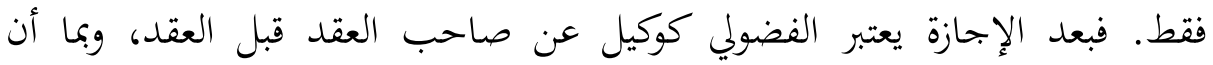

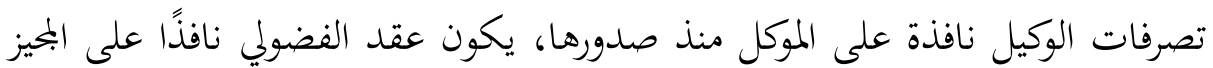

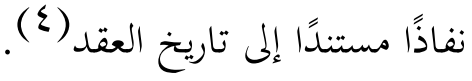
- المدة المقررة للإجازة: بالمدة المحددة على قولين: القول الأول: يذهب الحنفية إلى أنَّ الحق في إجازة العقد الموقوف يبدأ بعد إبرام

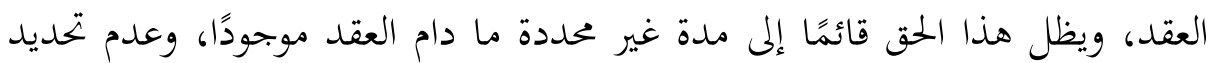

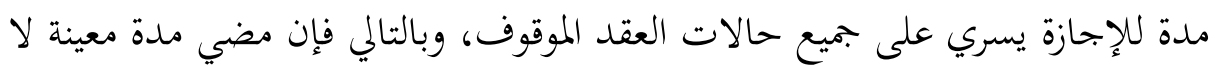

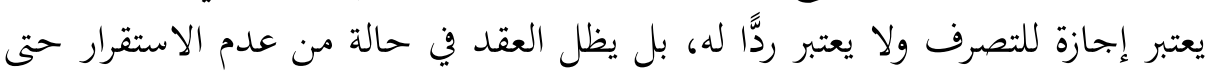

(1) ينظر: العقد الموقوف في القانون المدني الأردني، د/ عيسى محمد عبد القادر المومني، ص (.)

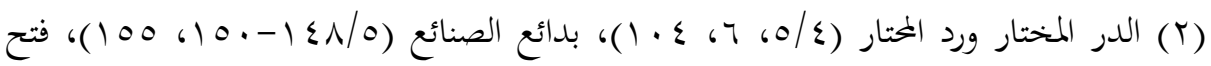

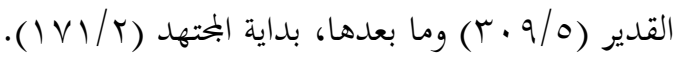

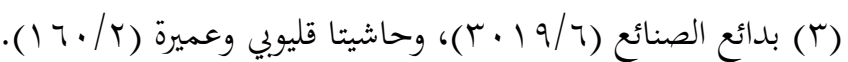

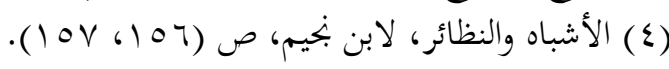


يتقرر مصيره إما بالرد والفسخ (')

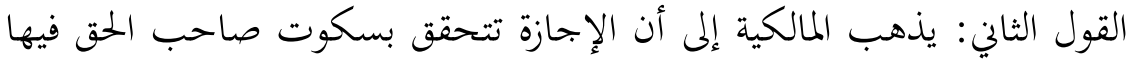

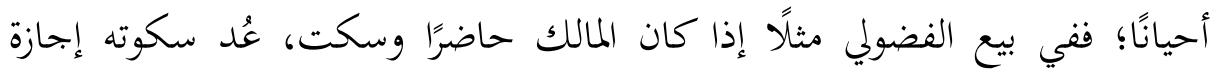

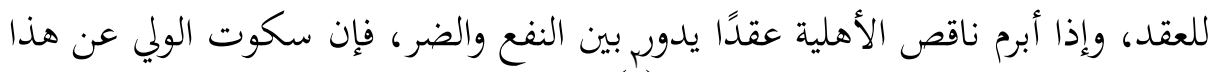

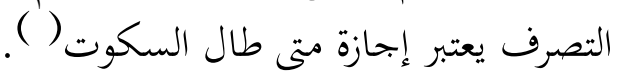
- المقارنة بين العقد الموقوف وبين العازه العقد القابل للإبطال:

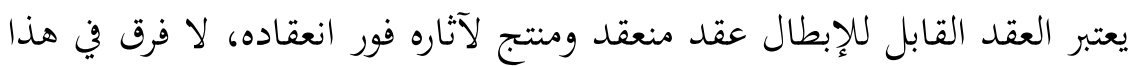

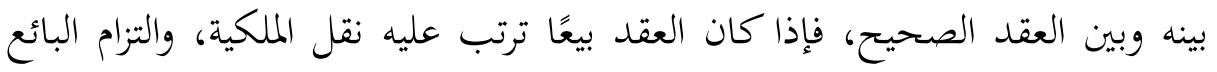

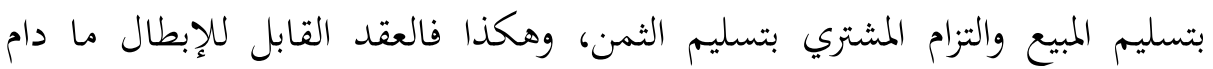

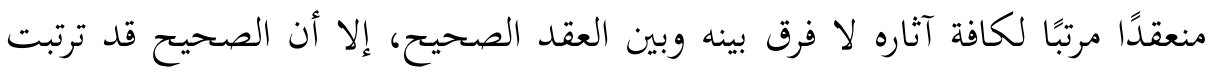

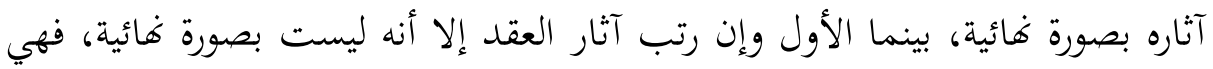
عرضة للزوال.

أمَّا العقد الموقوف فهو وإن انعقد صحيحًا، إلا أنه لا ينتج أثرًا، فهو موقوف

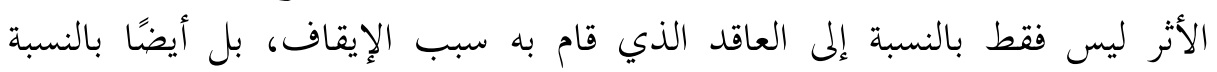
ل ل العاقد الآخر.

فالعقد الموقوف هو صورة عكسية للعقد القابل للإبطال، فالعقد الموقوف هو

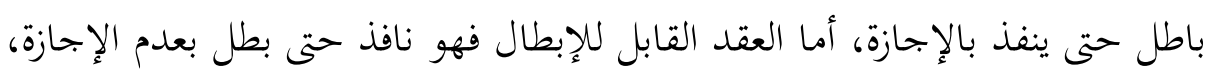

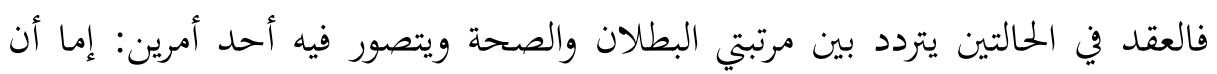

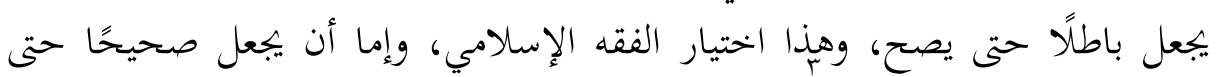

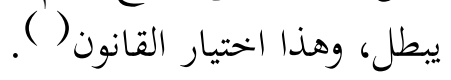

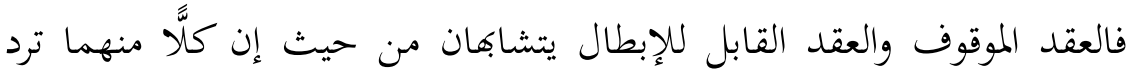

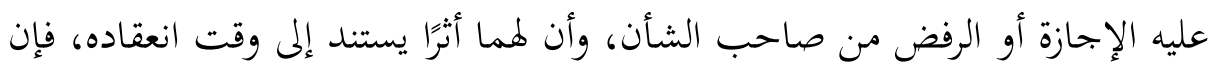

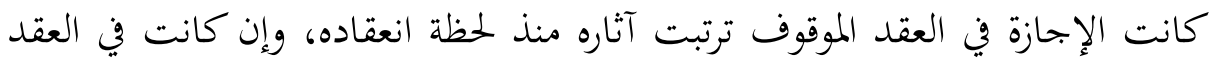

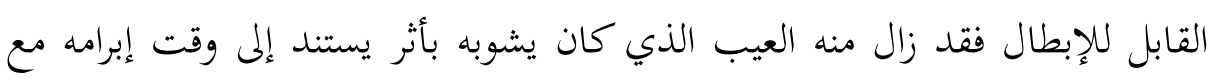

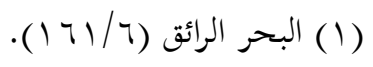

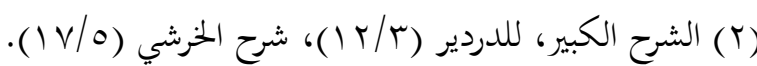

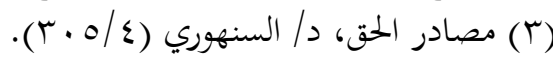


مراعاة حقوق الغير، وإن كان الرفض فالنتيجة واحدة بالاثنين، وهي اعتبار العقد كأن

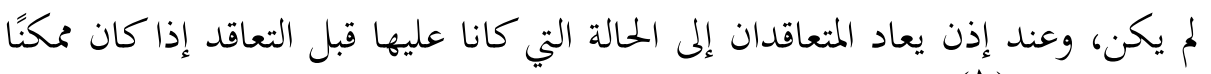
وإلا بالتعويض (1)

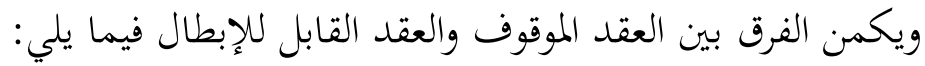

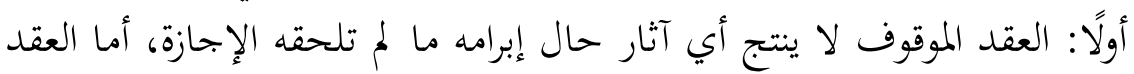

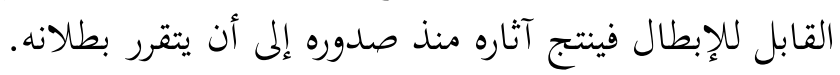

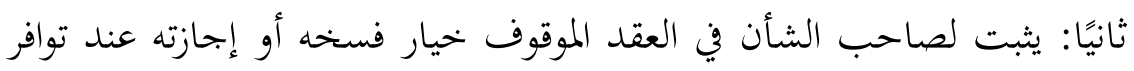

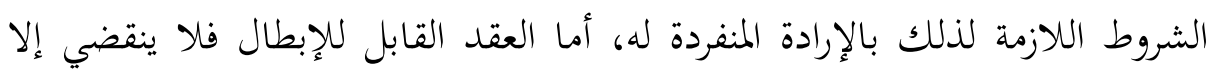

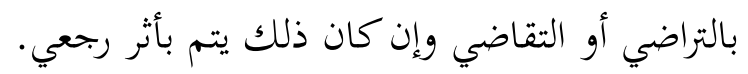

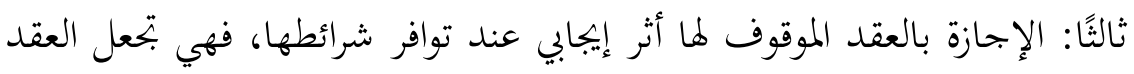

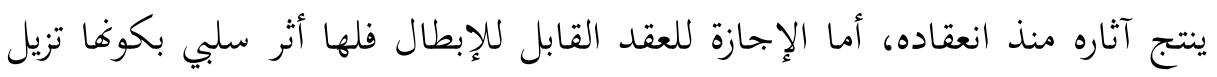
سبب بطانه.

رابعًا: التوقف وصف ثابت، يلحق العقد الذي لا تتوافر له أسباب نفاذه، وهي الملك

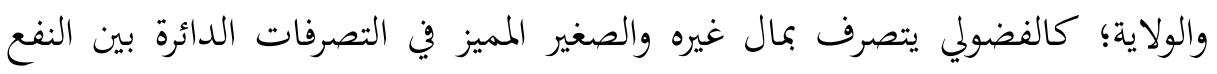

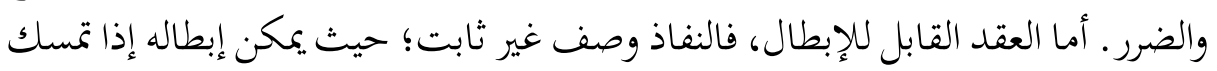
من له الحق في ذلك بالإبطال.

خامسًا: العقد الموقوف أوسع نطاقًا من العقد العقد القابل للإبطال، فهو يشمل

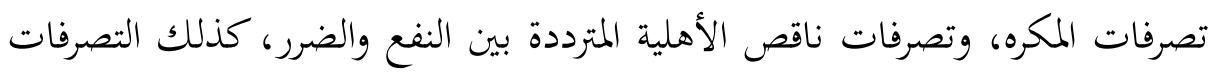

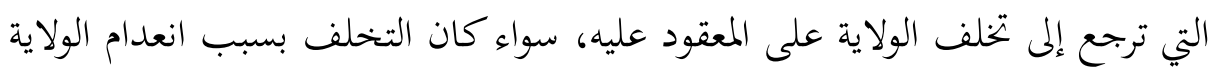

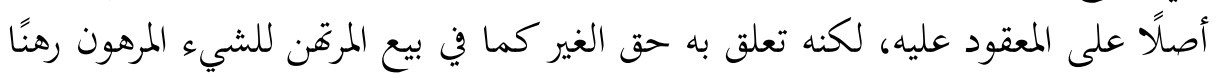
حيازيًّا.

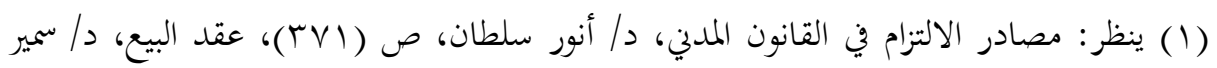

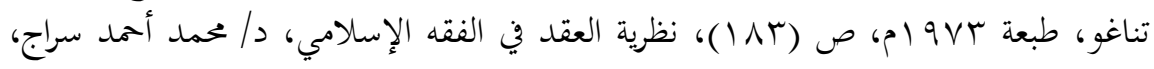

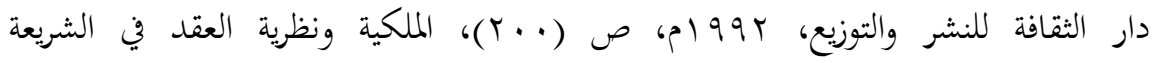

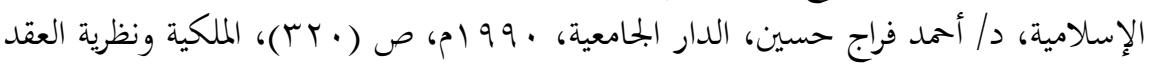

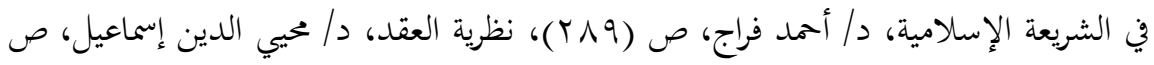


أما العقد القابل للإبطال فيقتصر على حالات نقص الأهلية وعيب الرضا، والحالات التي ينص القانون على أها قابلة للإبطال. ففكرة العقد الموقوف تفضل فكرة العقد القابل للإبطال في أن العقد الذي يشوبه لإبه

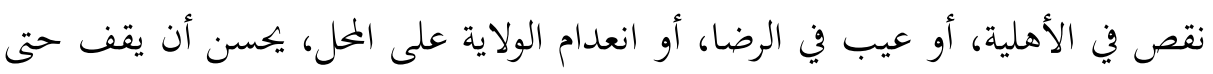

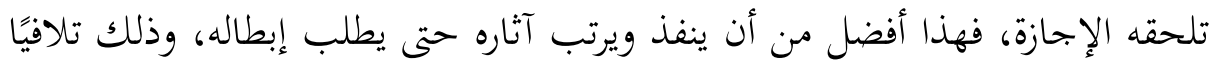

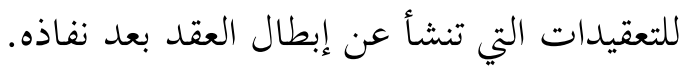

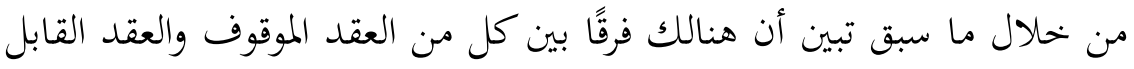

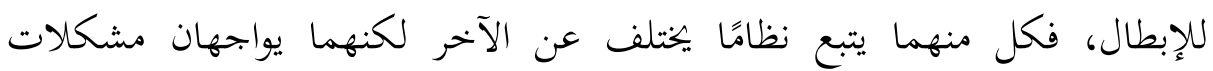
متشابهة.

ويمكن إبراز مظاهر تفضيل العقد الموقوف في النقاط التالية:

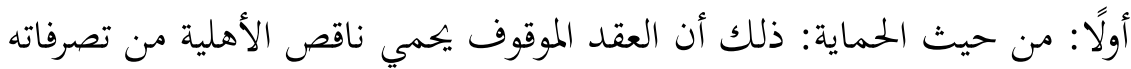

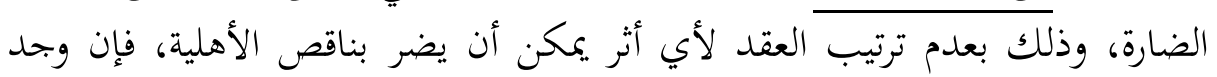

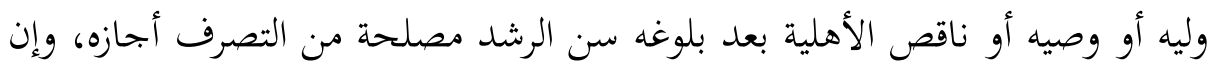

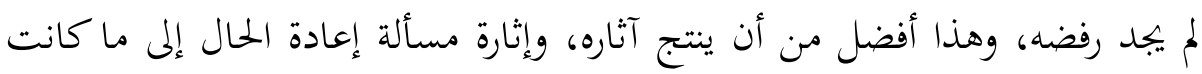

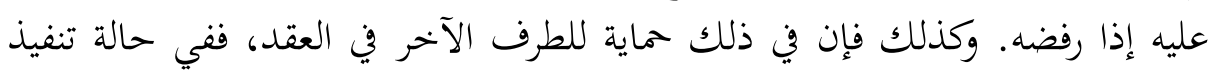

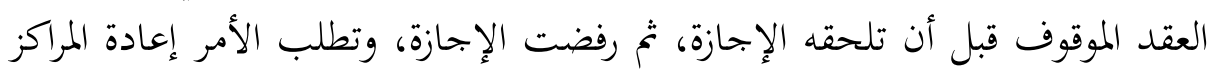

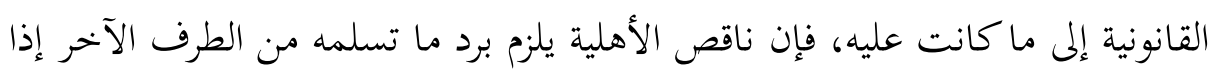

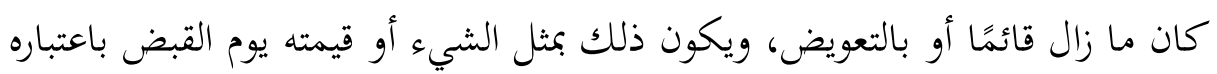

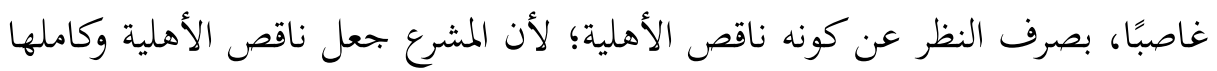

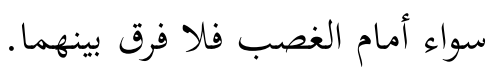

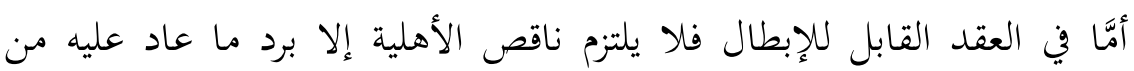
منفعة؛ حيث يعتبر بطلان العقد بمثابة جزاء على المتعاقد الآخر.

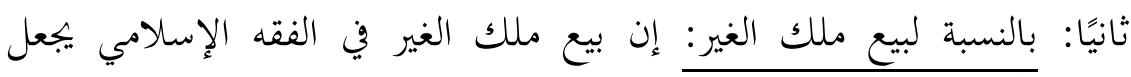

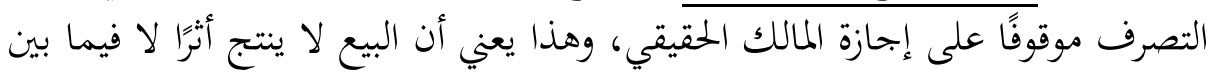
المتعاقدين ولا في مواجهة المالك الحقيقي.

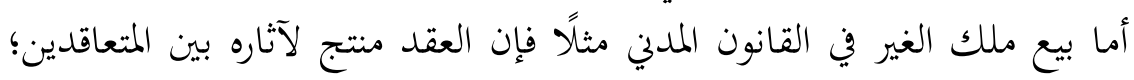

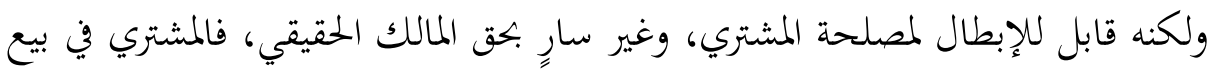


ملك الغير هو الذي تقرر الإبطال لمصلحته فهو يملك إبطال العقد ويملك إجازته،

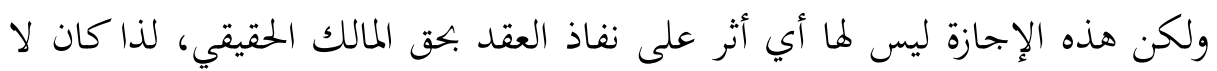

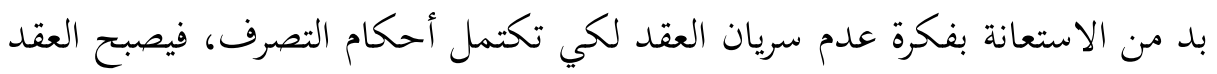

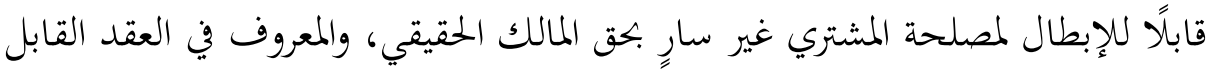

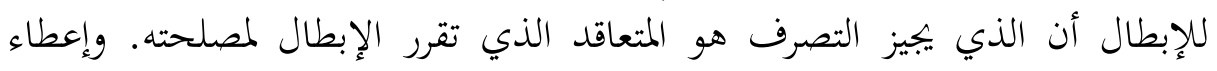

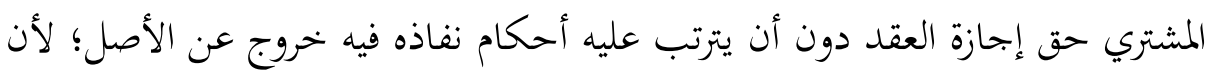

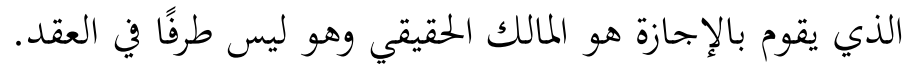

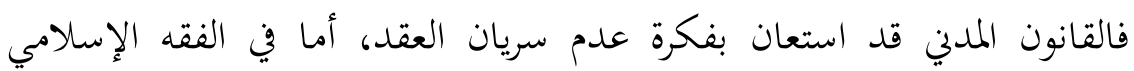

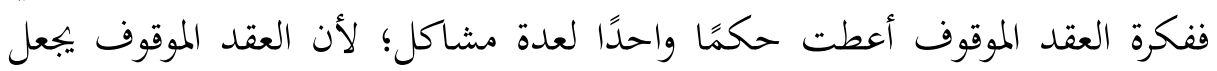

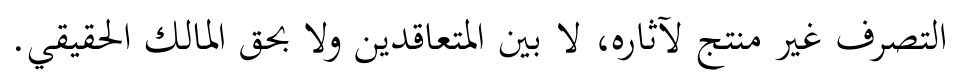

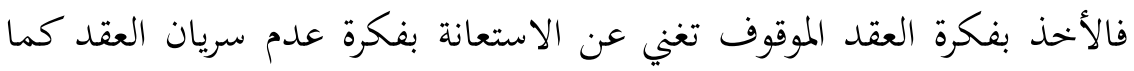

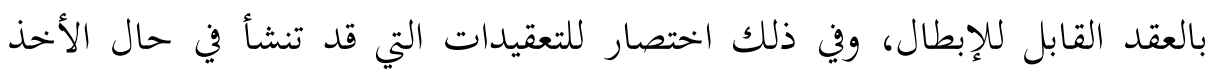
بفكرة العقد القابل للإبطال.

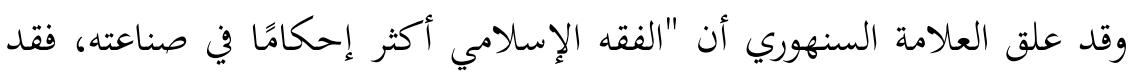

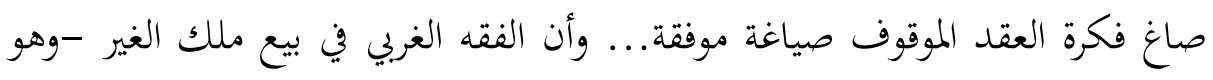

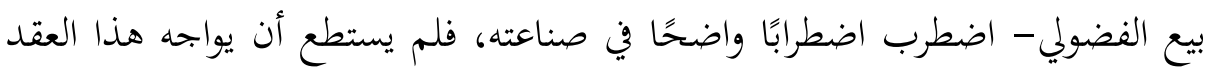

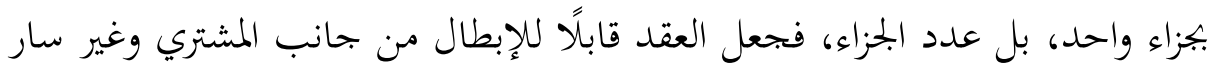

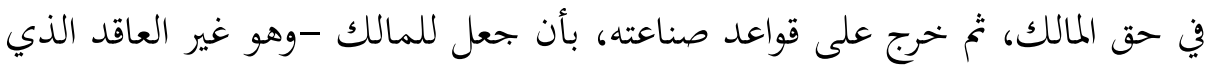

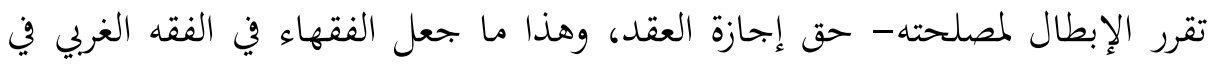
حيرة من أمر بطلان بيع ملك الغير يختلفون ويضطربون، ولا يصلون إلى حلى إلى واحلد، وهذا،

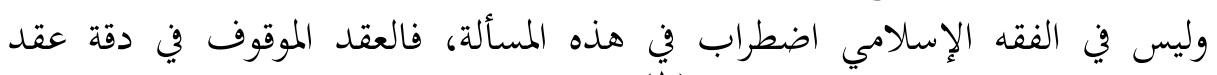

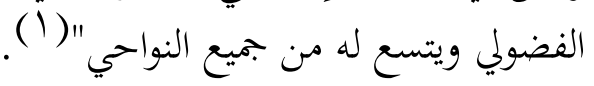

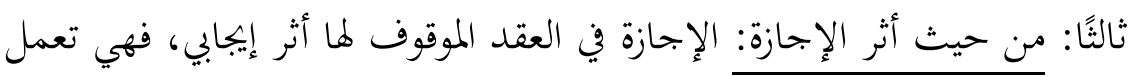

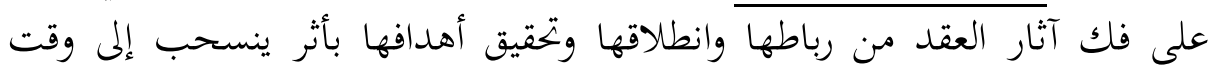

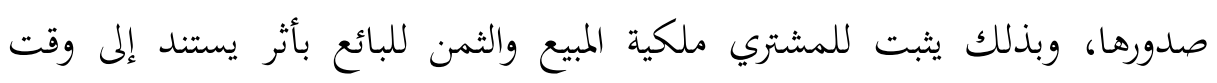


صدور العقد، أما إذا رفضه صاحب الشأن فلا يغير ذلك من الأمر شيئًا؛ لأن العقد

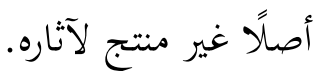

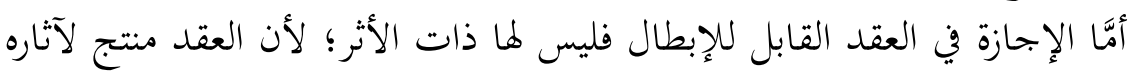

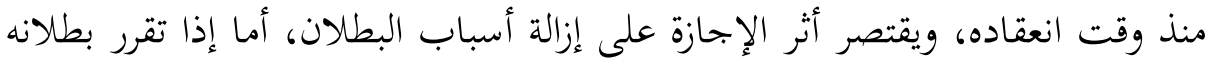

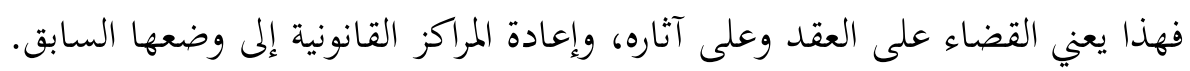

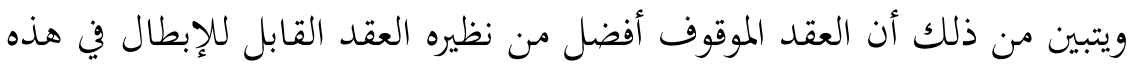

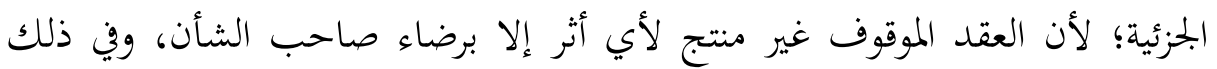

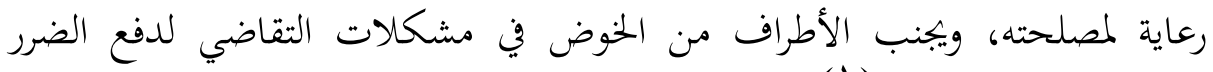

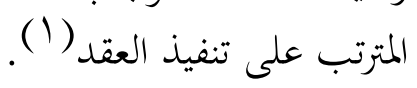

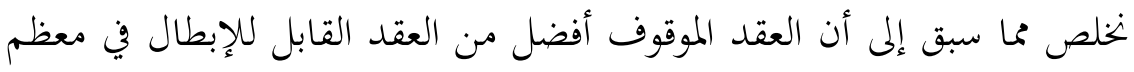

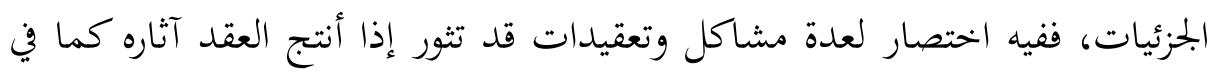

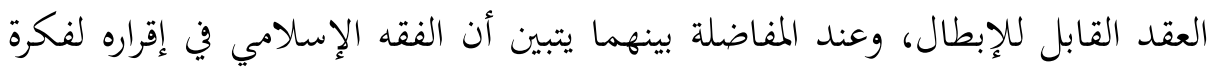

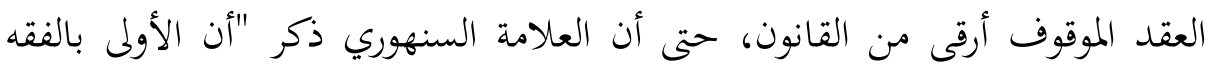

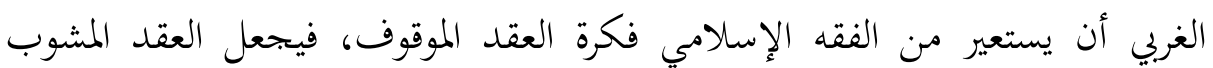

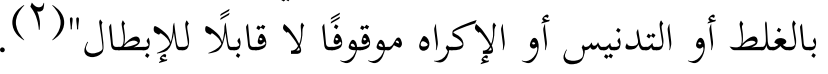

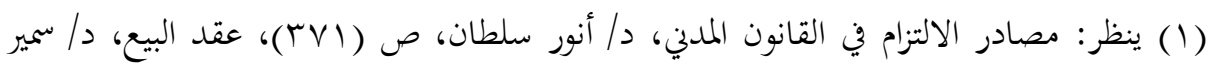

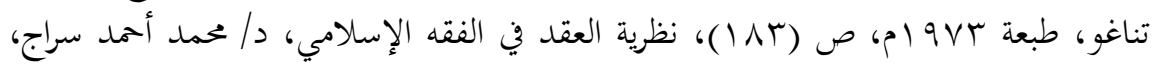

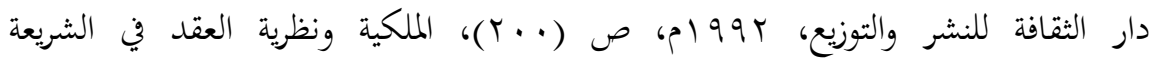

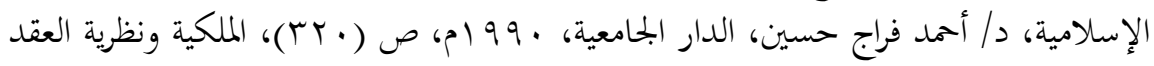

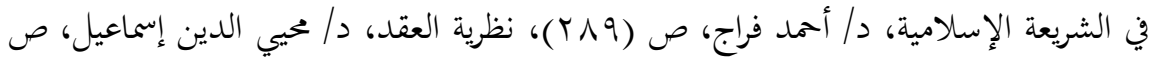




\section{خاتة}

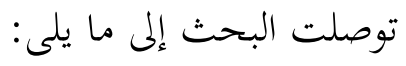

-

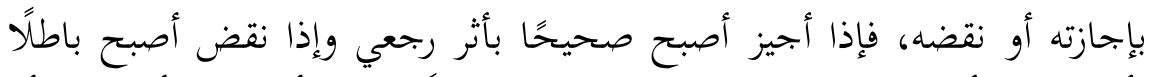

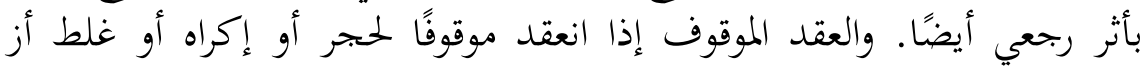

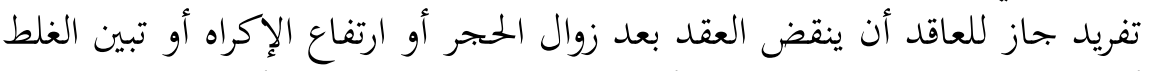

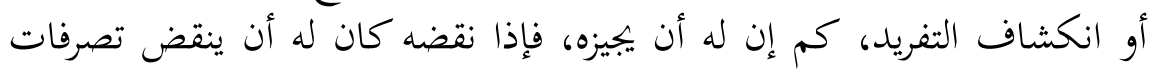

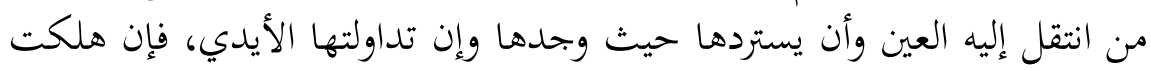

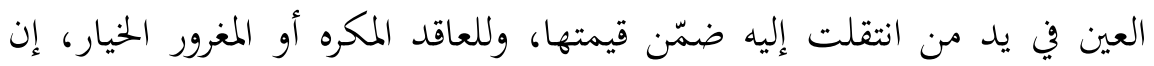

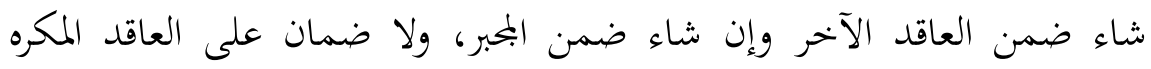

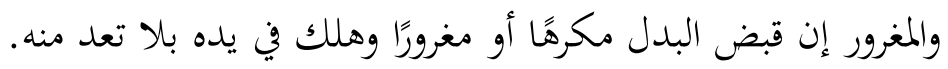

-

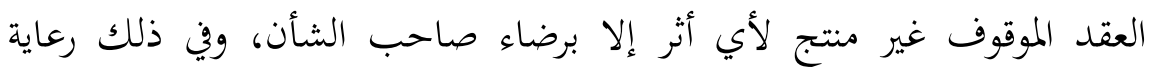

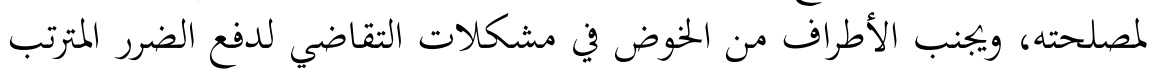
على تنفيذ العقد. -

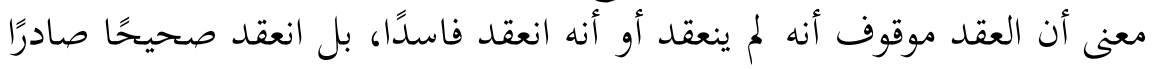

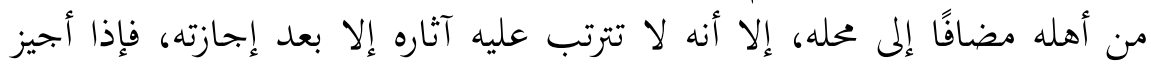

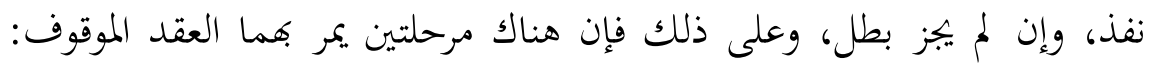
مرحلة ما قبل الإجازة، ومرحلة ما مالب بعد الإجازة.

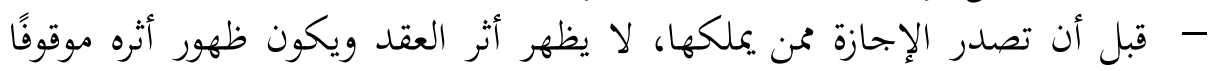

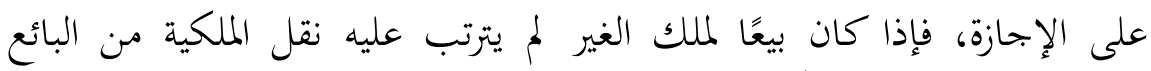

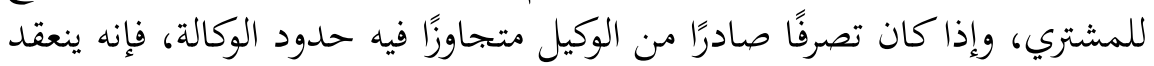

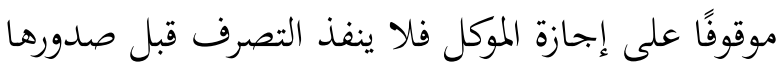
-

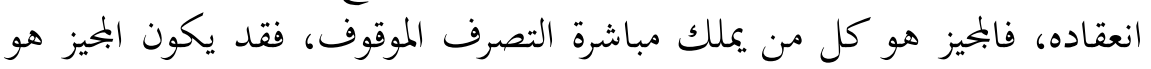

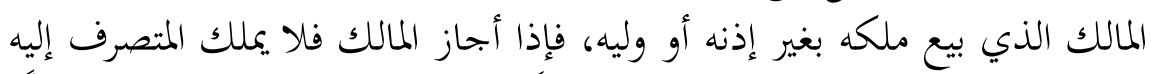

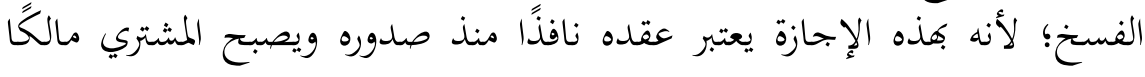

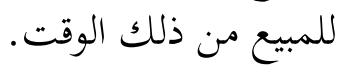




\section{المراجـــ}

$$
\text { - - - القرآن الكريك }
$$

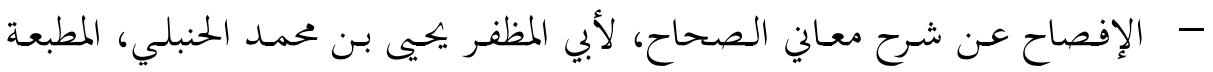

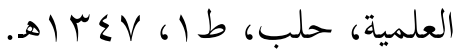

- الإفصاح عن معاني الصحاح في الفقه على المذاهب الأربعة، لأبي المظفر بن هبيرة،

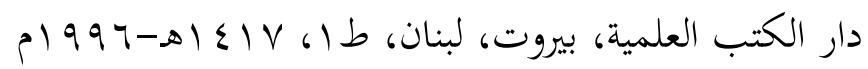

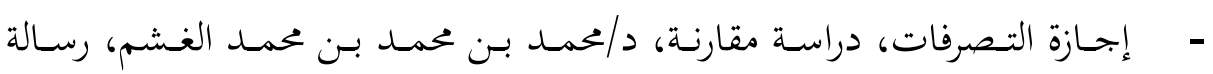

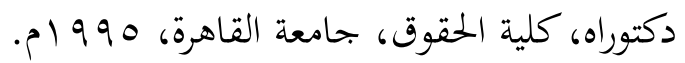
- إحكام الإحكام شرح عمدة الأحكام، لابن دقيق العيد، مطبعة السنة المحمدية، بدون طبعة، وبلدون تاريخ.

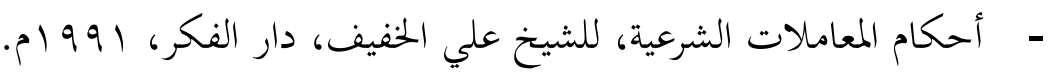

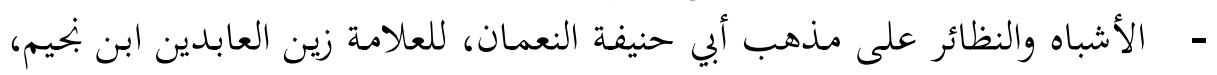
طبع مؤسسة الحلبي، القاهرة.

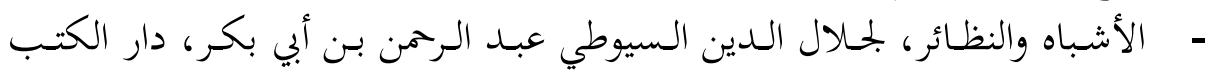

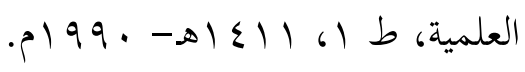

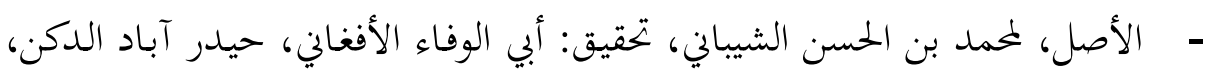

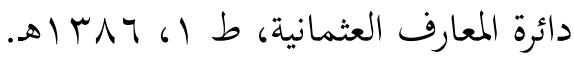

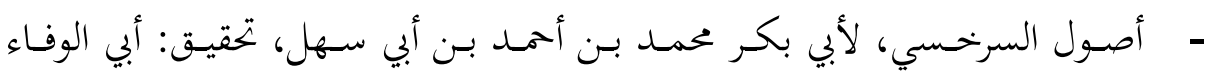

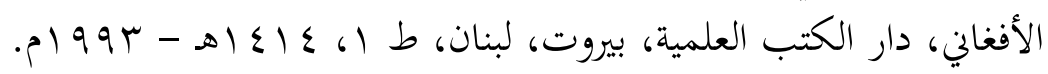

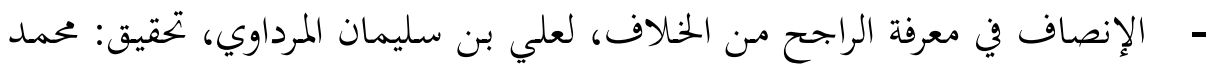
حامد الفقي، دار إحياء التراث العربي.

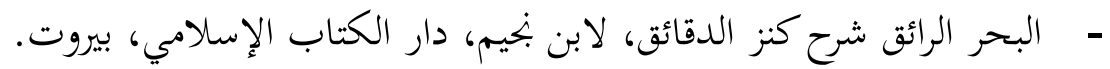

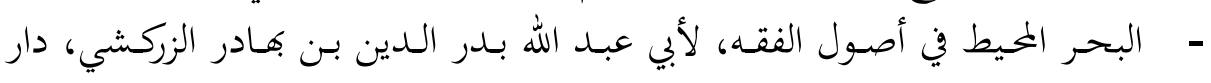

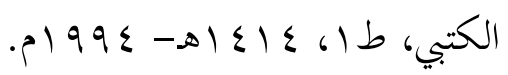

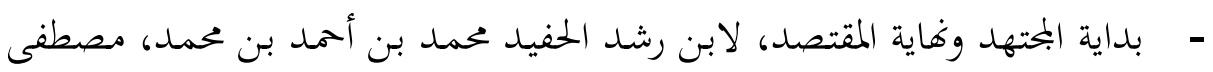

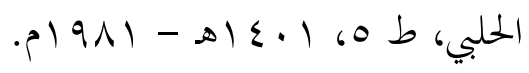


- بدائع الصنائع في ترتيب الشرائع، لعلاء الدين أبي بكر بن مسعود الكاساني، طبعة

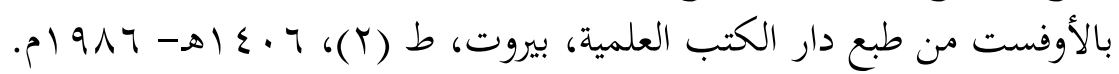

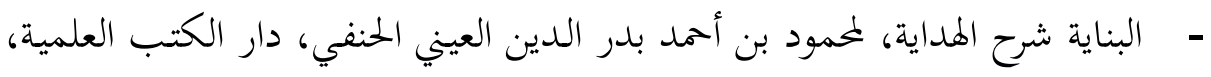

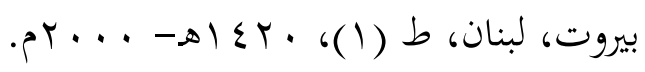

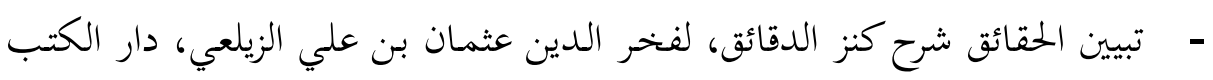

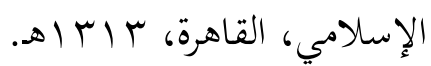

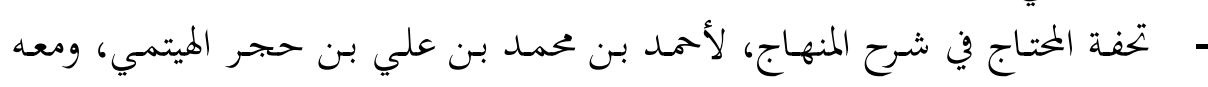

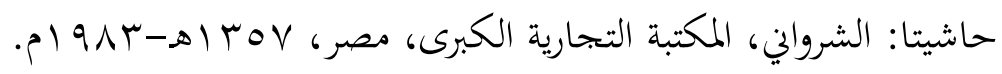

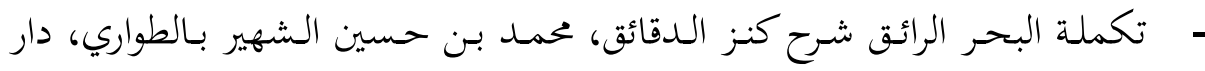
المعرفة، بيروت، لبنان.

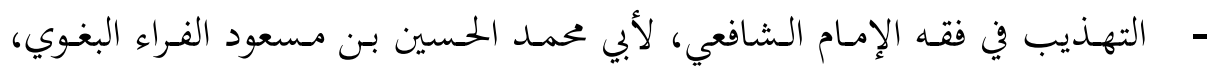

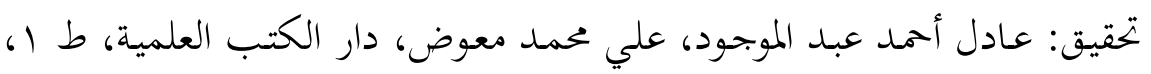
. $199 \mathrm{~V}-01 \leqslant 11$ - جواهر الإكليل شرح مختصر خليل، للعلامة صالح عبد السميع الأزهري، عيسى اهی الحلبي، القاهرة. - حاشية ابن عابدين، لمحمد أمين الشهير بابن عابدين الدمشقي، المسماة رد المحتار

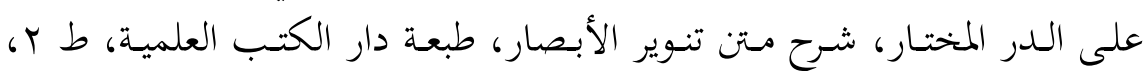
. $999-8|\leqslant| r$ - حاشية الدسوقي على الشرح الكبير، لشمس الدين الشيخ محمد عرفة الدسوقي، دار إحياء الكتب العربية، القاهرة. - حاشية نسمات الأسحار، لابن عابـدين، مطبعة مصطفى البابي الحلبي، القـاهرة، . DTh - حاشيتا قليوبي وعمـيرة، لأممد سلامة القليوبي، وأحمد البرلسي عميرة، دار إحياء

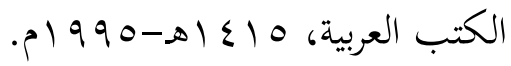

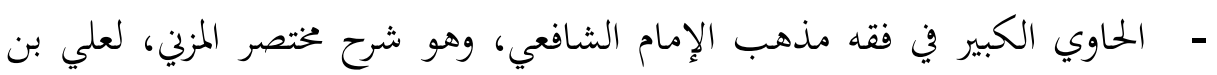

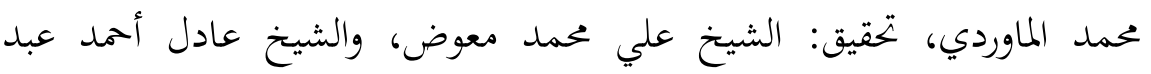

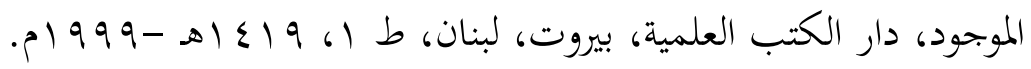


- الدر المختار شرح تنوير الأبصار، لمحمد بن علي علاء الدين الحصكفي الدمشقي

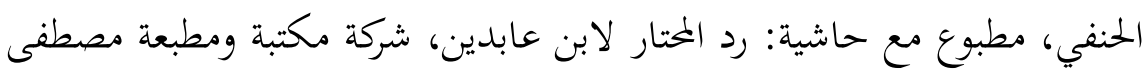

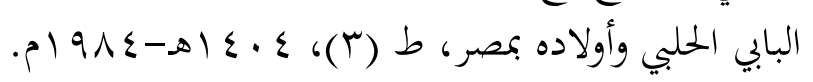

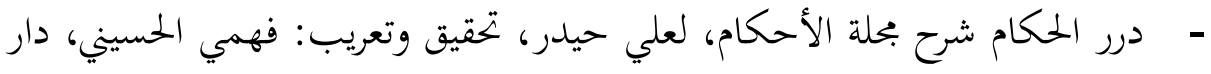
الكتب العلمية، لبنان، بيروت.

- رسالة ابن أبي زيد القيرواني، لعبد الله بن أبي زيد القيرواني أبو محمد، دار الفكر، بيروت.

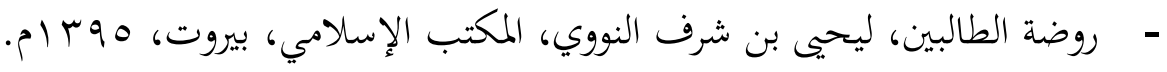

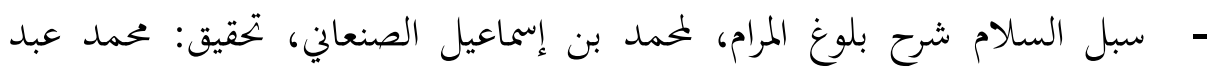

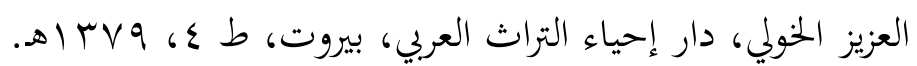

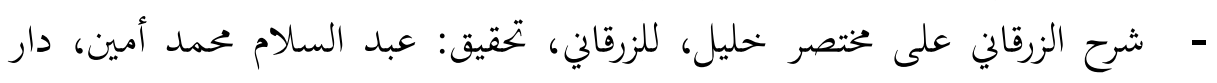

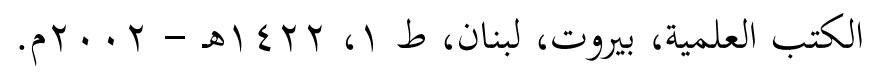

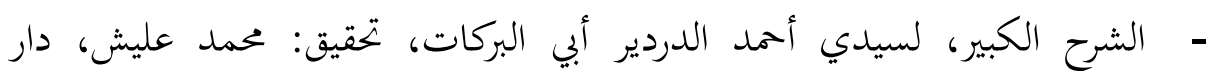
الفكر، بيروت.

- شرح الكوكب المنير المسمى بمختصر التحرير أو المختبر المبتكر شرح المختصر في

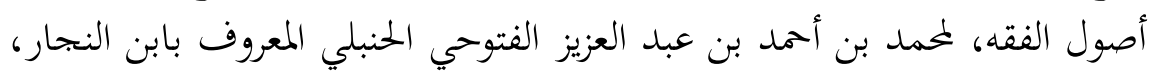

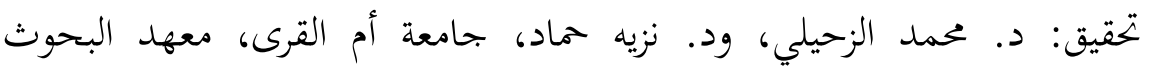

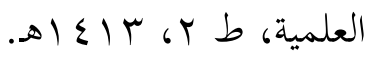

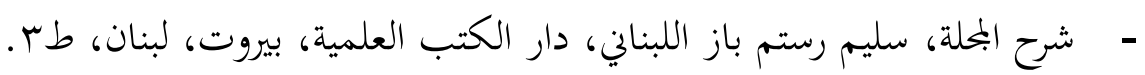

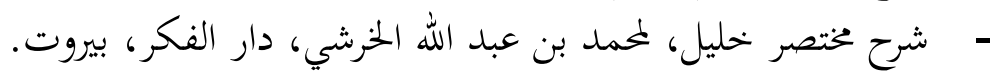

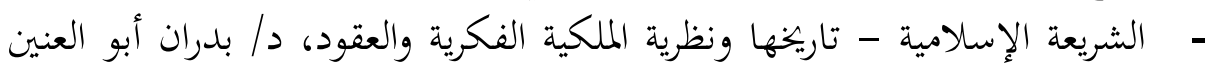
بدران، مؤسسة شباب الجامعة، الإسكندرية.

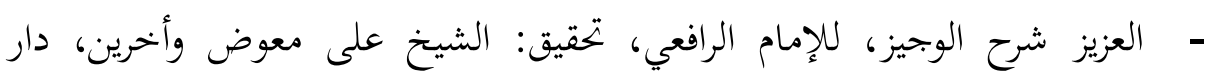

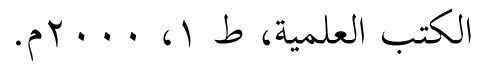

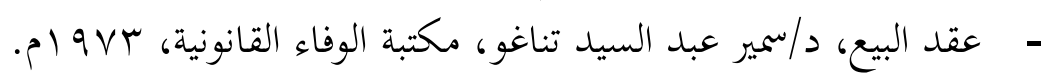

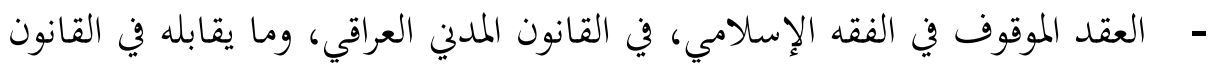

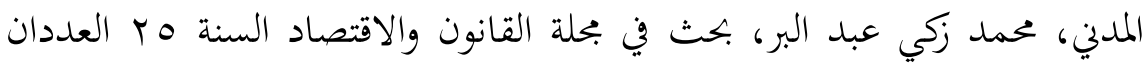




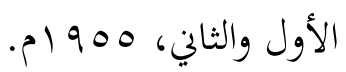

- العقد الموقوف في القانون المدني الأردني، داعيسى محمد عبد القادر المومني، رسالة دكتوراه، جامعة عين شمس.

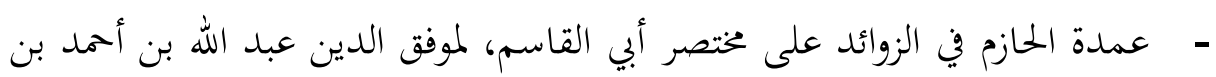

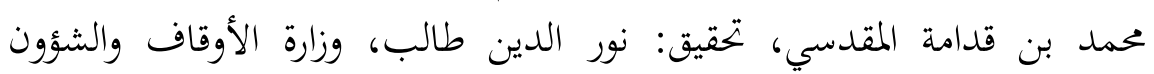

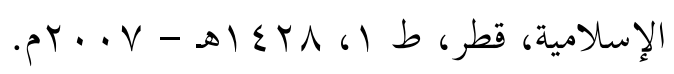

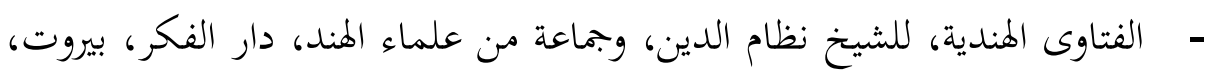
$.01991-\infty|\leqslant| 1$

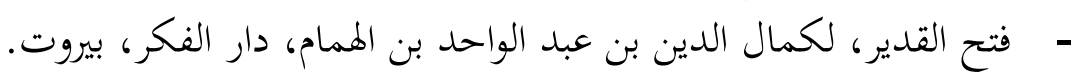

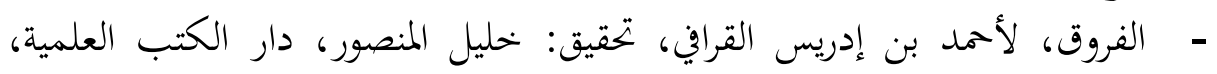

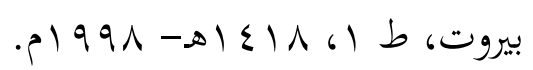

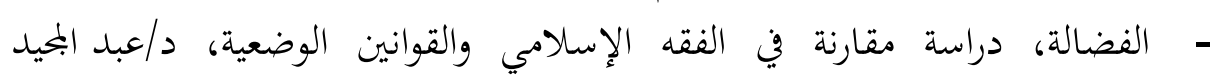
مطلوب، مطبعة نيفرتيتي.

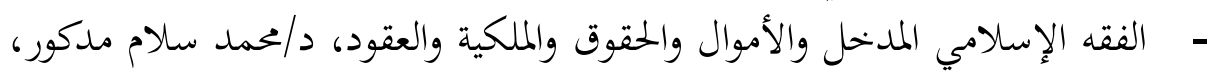

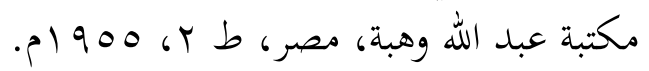

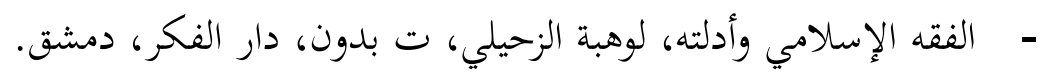

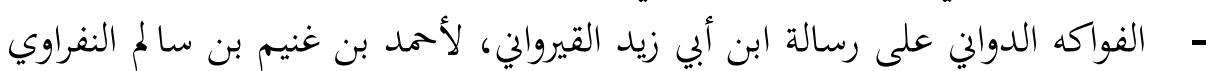

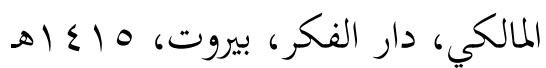

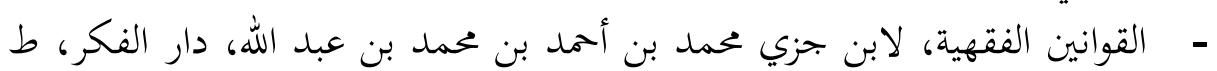
. 191061 - الكافي في فقه الإمام أحمد، لموفق الدين عبد الله بن أحمد بن قدامة المقدسي، دار

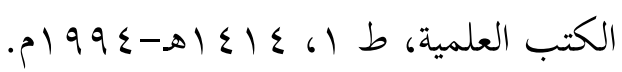

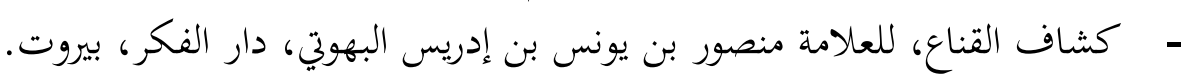

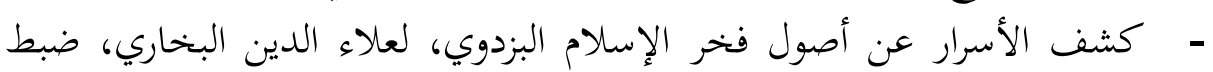

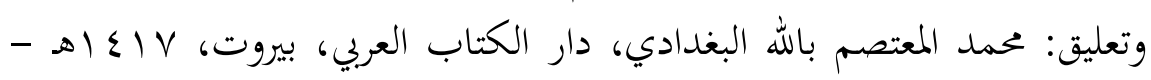
. $199 \mathrm{~V}$ - كشف الأسرار، للإمام أبي البركات عبد الله بن أحمد المعروف بحافظ الدين 
النسفي مع شرح نور الأنوار على المنار، لملالا جيون بن أبي سعيد الحنفي لبني الصديقي، دار الكتب العلمية، بيروت، لبنان.

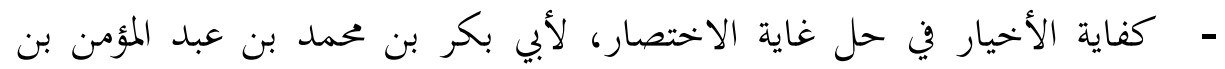

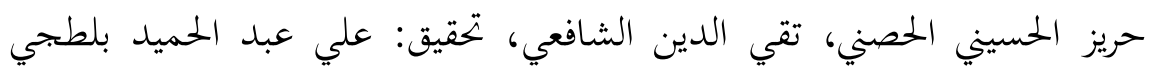

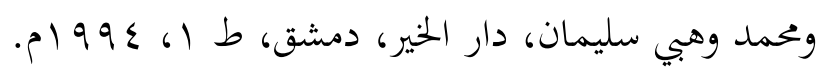

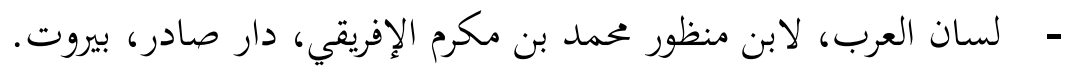

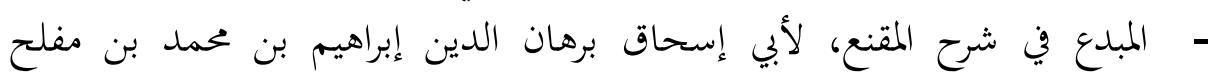

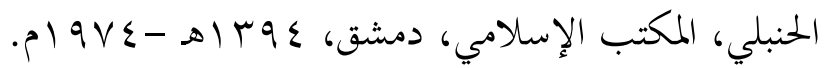

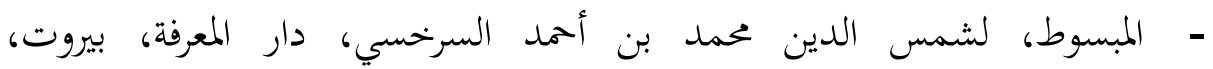

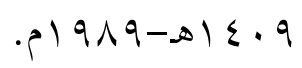

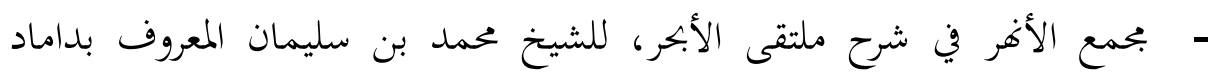

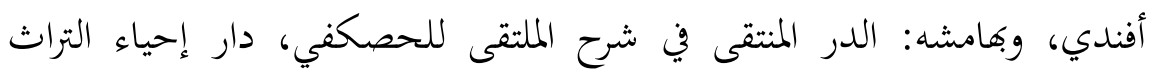
العربي، بيروت.

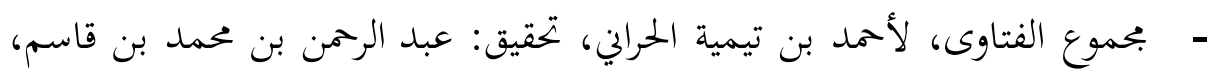

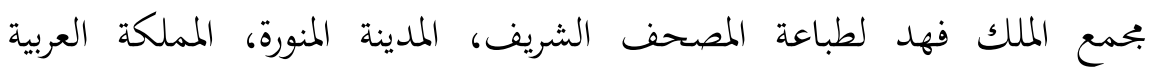

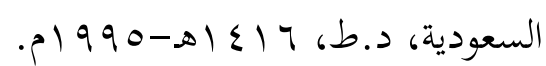

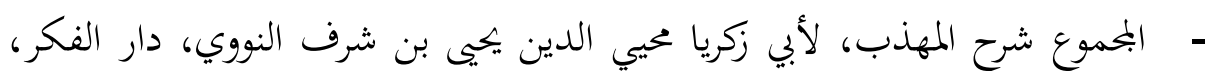
بيروت. - المحلى بالآثار، بعلي بن أحمد بن حزم الظاهري، دار الفكر، بيروت، بدون طبعة وبدون تاريخ.

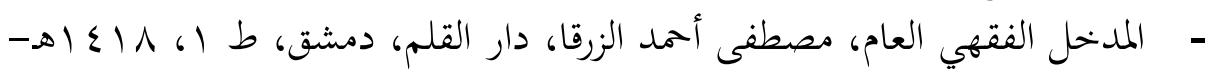
.01991 - - المدخل لدوراسة الفقه الإسلامي، دو/محمد فرحات، النهضة العربية، القاهرة، .

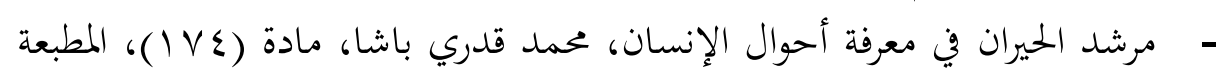
الأميرية، القاهرة. - مصادر الالتزام في القانون المدني الأردني، دراسة مقارنة بالفقه الإسلامي، د/أنور 


$$
\text { سلطان، دار الثقافة للنشر والتوزيع، عمان، ج ـ . ب م. }
$$

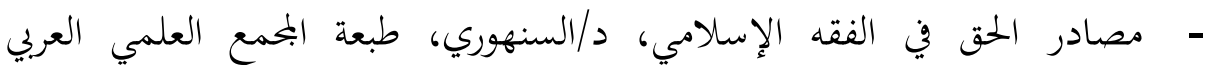

$$
\text { الإسلامي، بيروت. }
$$

- المصباح المنير في غريب الشرح الكبير، لأممد بن محمد بن علي المقري الفيومي،

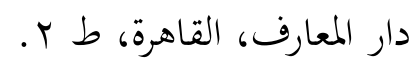

- - مطالب أولي النهى في شرح غاية المنتهى، للشيخ مصطفى السيوطي الرحيباني،

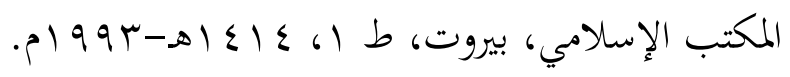

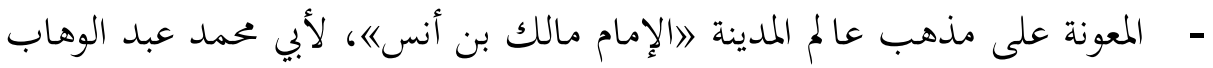

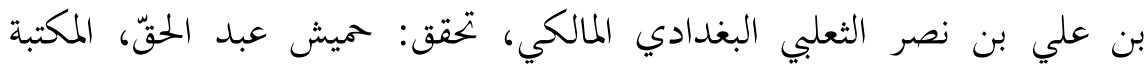

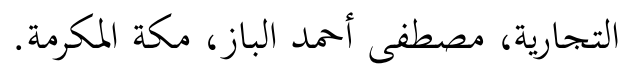

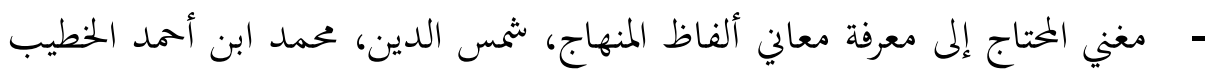

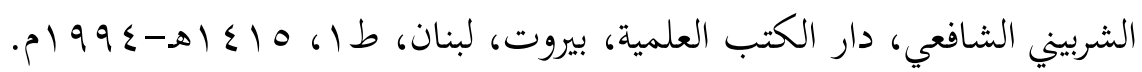

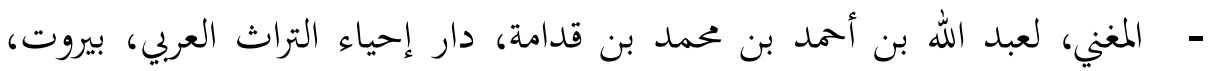

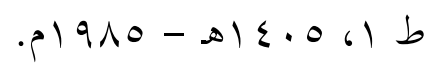

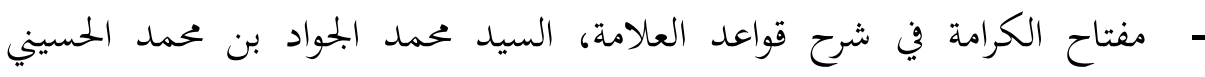

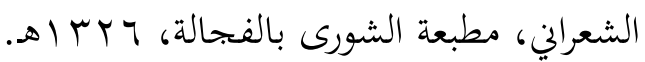

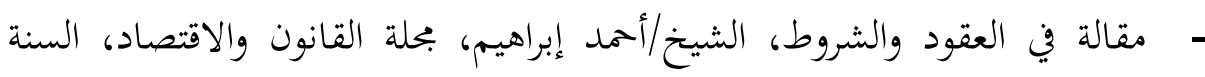

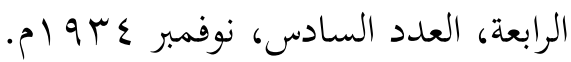
- الملكية ونظرية العقد في الشريعة الإسلامية، الإمام محمد أبو زهرة، دار الفرام الفكر

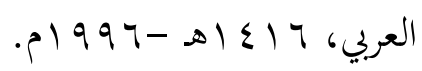

- الملكية ونظرية العقد في الشريعة الإسلامية، دأهمد فوراج حسين، الدار الجامعية،

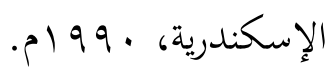

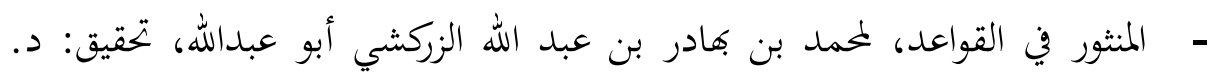

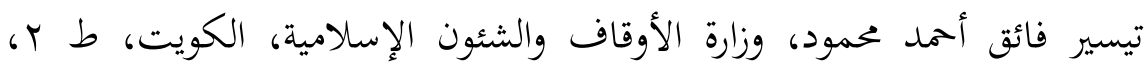

$$
\text { أهـ }
$$

- إلمهذب في فقه الإمام الشافعي، لإبراهيم بن علي بن يوسف الشيرازي أبو إسحاق، دار الفكر، بيروت. 
- مواهب الجليل لشرح مختصر خليل، لمحمد بن عبد الرحمن المغربي أبي عبد الله، دار

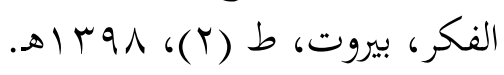

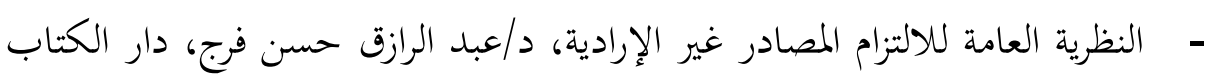

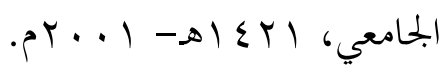

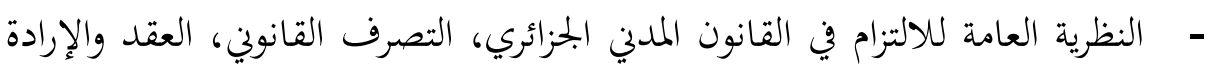

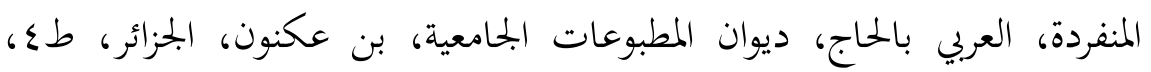

$$
\text { ק. O } 0
$$

- النظرية العامة للموجبات والعقود، لصبحي محمصاني، بيروت، مطابع الكشاف.

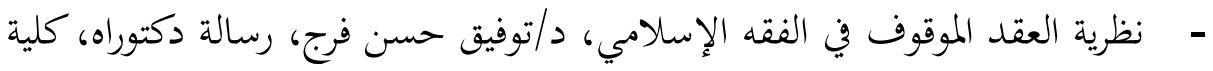

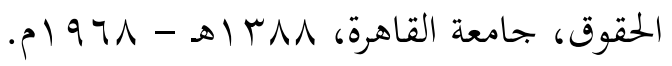
- نظرية العقد في الفقه الإسلامي، دامعمد أحمد سراج، دار الثقافة للنشر والتوزيع،

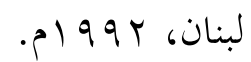

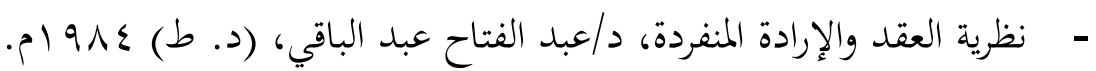

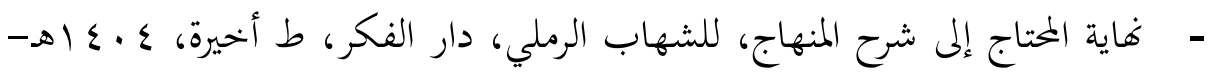

$$
\text { . }) 9 \wedge \varepsilon
$$

- - النوادر والزيادات على ما في المدونة من غيرها من الأمهات، لأبي محمد عبد الله

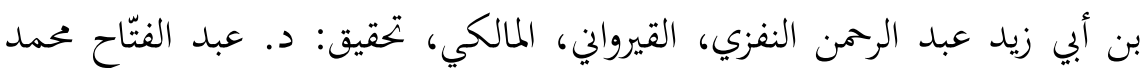

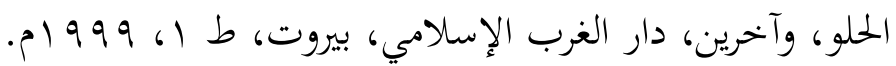

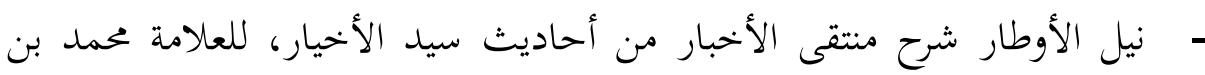

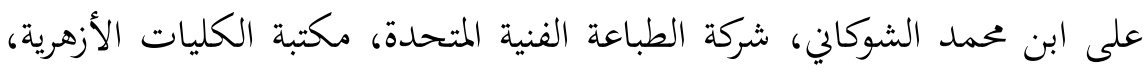
$.019 V \varepsilon$ - الهداية شرح بداية المبتدي، لأبي الحسن علي بن أبي بكر بن عبدابلحليل الرشداين

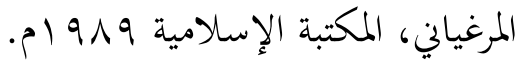
- الوجيز في أصول الفقه، د. عبد الكريم زيدان، طبعة مؤسسة الرسالة، بيروت، . $191 \mathrm{~V}$ 